\title{
MEASURING THE PRESIDENTIAL POWERS: NEW GOVERNMENTAL DESIGN IN TURKEY
}

\author{
Başkanlık Yetkilerinin Ölçülmesi: Türkiye’de Yeni Hükümet \\ Sisteminin Yapısı
}

Demet ÇELİK ULUSOY*

\begin{abstract}
The new form of government has significantly transformed the executive power in Turkey. The legislative and the judiciary organs are mostly affected by the alterations but not in a good way. Since the system has supremely transformed the executive and its transactions. Forms of government cannot be identified merely by examining the structure of legislative and executive organs and their interrelations. In addition the new so-called Turkish presidential system does not adapt to the existing definitions and element well known sustainable forms of government. As the first the system will be described generally based on patterns of different presidentialism. Many researchers point out that the President in the new system is more powerful than those in pure presidential systems. It is noted that there are presidents in hyper models who are more potent than those in pure presidentialism. In this regard, the system will be analysed based on the President's powers since it cannot be defined through traditional methods and elements of pure presidential system. The powers of the presidents in the pure and hyper presidential models will be compared with the President's powers. The aim is to determine whether there is a well-found president with extreme powers as claimed theoretically. Finally, while discussing the framework of the system, the recent debates on the form of government and the President's several disputable powers will be analysed.
\end{abstract}

Keywords: Presidential systems, hyper-presidentialism, presidential powers, presidential legislative powers of the president, non- legislative powers of the president.

Makalenin Geliş Tarihi: 26.01.2021, Makalenin Kabul Tarihi: 05.04.2021.

Dr. Öğr. Üye., Doğu Akdeniz Üniversitesi Hukuk Fakültesi Anayasa Hukuku Anabilim Dalı. ORCID: 0000-0002-5542-9467, demet.celik@emu.edu.tr. 


\section{Özet}

Türkiye'de yeni hükümet sistemi yürütme gücünü önemli ölçüde değiştirmiştir. Değişiklikten, yasama ve yargı organları oldukça etkilenmişlerdir. Zira yeni sistemde yürütme oranı ve işlemleri üstün bir şekilde dönüştürüldüğünden bu etkilenme iyi yönde olmamıştır. Hükümet şekli sadece yasama ve yürütme organlarının inşası ve ilişkileri incelenerek tanımlanamaz. Yeni Türk tipi başkanlık sistemi olarak adlandırılan bu yeni sistem de yönetim biçimlerinin mevcut tanımları ve unsurlarına uyum sağlayamamaktadır. Ayrıca birçok araştırmacı, yeni sistemdeki Başkan'ın saf başkanlık sistemlerindekilerden daha güçlü olduğuna işaret ediyor. Buna ek olarak hiper başkanlık modellerinde başkanlık sistemindeki modellerden daha güçlü başkanlar olduğuna dikkat ediliyor. Bu yüzden öncelikle yeni sistemin farklı başkanlık sistemleri örüntüleri esas alınarak genel olarak tanımı yapılmalıdır. Öte yandan, geleneksel yöntemlerle yeni hükümet şekli tanımlanamayacağından Cumhurbaşkanı'nın yetkilerine göre yeni sistem analiz edilmeye çalışılacaktır. Buna göre amaç hükümet sistemini değerlendirmek ve teorik olarak iddia edildiği gibi aşırı güçlere sahip iyi kurulmuş bir başkan olup olmadığını belirlemektir. Saf başkanlık sistemi ve hiper başkanlık olarak nitelenen örneklerdeki başkanların yetkileri, yeni sistemdeki Başkan'ın yetkileriyle karşılaştırılacaktır. Son olarak, hükümet sisteminin çerçevesi tartışılırken, hükümetin şekli ve Başkan'ın tartışmalı birçok yetkisi hakkındaki tartışmalara da değinilecektir.

Anahtar Kelimeler: Başkanlık sistemleri, hiper-başkanlık, başkanlık yetkileri, başkanın yasama yetkileri, başkanın yasama dışı yetkileri.

\section{Introduction}

The principles of the rule of law and separation of powers are interconnected. The rule of law refers to, among other things, persistence for being governed by a process in response to the institutional articulation required by separation of powers. In other words, law-making has to precede adjudication, administration and the entailed due process ${ }^{1}$. Rules of law should exist before their application. This order becomes blurred in some cases in certain countries. Despite the compliance of the "we are public" phenomenon with the U.S. Constitution, it is impossible to disagree with this statement, which projects public participation in the democratic constitutional regime ${ }^{2}$.

1 Waldron, J; Separation of Powers in Thought and Practice, Boston College Law Review, 54(2), pp.433-468, p.459.

2 Constitutional amendments which are altered the form of government entered into force upon a referendum. It cannot be asserted that these methods, in which the public's preferences "for the public", always yield democratic outcomes. Entrenched in 
In Turkey, the search for a governmental system has been an endless dispute either for "a sustainable democracy" or an actual "constitutional democratic" regime ${ }^{3}$. Sustainable and effective governance claims to require strong execution and a powerful president. Especially those exercising political power claim that a stable democracy will be established with a strong executive and often makes the electors believe it. For long years, it has been emphasised that the presidential system would bring democracy to Turkey ${ }^{4}$.

The most important feature of the constitutional amendments on 16 April $2017^{5}$ was the envisioned governmental structure in Turkey, which was discussed from time to time but had never been attempted. The constitutional amendments have primarily created a remarkable change in the design of the

contemporary constitutionalism as a device for calling people to decide, the referendum has often been the tool for instating plebiscitarian democracies. It is also necessary to impart the following findings about the referendum. Referenda can be oppressed to achieve majoritarian decisions. Particularly, in a political environment having solid social divisions. Moreover in a political environment with strong societal divides. Actually, it is claimed that referenda foster a majoritarian governance and populist leaders recur to them consciously. It is also asserted that people frequently reward charisma more than accurate explanations about the referendum's real content. This is because they lack technical competences for taking relevant political decisions. Embedded in modern constitutionalism as a method for calling individuals to adopt the referendum has often been the instrument for establishing plebiscitarian democracies. Scotti, Valentina Rita; Constitutional dismemberment via referenda: A Comparative Overview, Revista de Investigações Constitucionais, 7(3), 2020, pp. 795-811. , p. 795-796,https://doi.org/10.5380/rinc.v7i3.74334. Without knowing what the proposed system is or whether it is the pure presidential system or not, most people tend to vote for a charismatic leader or in similar with ideas they believe in.

3 Batum, Süheyl, 1990'larda Dünyada ve Türkiye'de Siyasal Rejim Tartışmalar, Siyasal Rejim Tartışmaları içinde, Nihal İncioğlu (Ed.), TESEV Yayınları, Ankara, 2000, p.64.

4 Kılınç, Doğan; Türkiye'de Bitmeyen Tartı̧̧a: Hükümet Sistemi Üzerine Değerlendirmeler, Ankara Hacı Bayram Veli Üniversitesi Hukuk Fakültesi Dergisi, N.20.1, 2016, pp.447-510.

5 Turkey has switched to a new regime, 6771 no. Constitutional Amendment Law, through a referendum, held on 16 April 2017 that will take full effect of approval of the amendments. According to the decision No. 663 of the Higher Election Board, as a result of the referendum on constitutional amendments was adopted with $51.41 \%$ of the vote, 2017 . The in-effect dates of the three groups of amendments were different from each other, and some of them were proposed by the constitutional amendment. The most significant dimension of the regime-altering amendments was the elections made along with the legislature and presidential as a result of the date on which the President's sworn entered into force. These elections were held on June 24, 2018. The constitutional amendments were come into force with the President's inauguration on 9 July 2018. See for the results of the referenda, Turkish High Election Board, Decision 663, 2017. Retrieved from http://www.ysk.gov.tr/doc/karar/dosya/5064/2017-663.pdf. 
executive organ ${ }^{6}$. Additionally, as was the case in the pure presidential system, these amendments created a sole executive body unprecedented in Turkish constitutional history ${ }^{7}$. Moreover, this new model of government was not entirely suitable in any of the model classifications of different forms in the literature. The current Turkish type of presidentialism has never existed in constitutional history. Therefore, the President has become both the head of the executive and the head of the state. Undoubtedly, the first concept implied by the phenomenon of a single executive system is the pure presidential system.

At present, studies on the new regime, which includes a compelling president, have been launched. At this point, the most considerable criticism has been related to the dominant and robust President. Until now, all we know is that there is a single-structured executive branch in the system ${ }^{8}$ with a president with extreme powers. Therefore, the system neither predicts a pure presidential system nor any other sustainable or stable form of government because of the presidential dominance and powers. The system presented is therefore called the Turkish-type presidential system due to its unique or chaotic nature.

The newly Turkish-type presidential system is similar to the super presidential system only in terms of the degree of presidential powers, yet differs in institutional dimension. In Turkey, a cabinet was reporting to the parliament before the aforesaid constitutional amendments such as super presidentialism, but this was eliminated with the constitutional amendments in $2017^{9}$. It should be noted that the executive organ's single structure is not sufficient to define the system as pure presidential. Most studies stated that

6 Esen, Selin; Anayasa Değişiklik Teklifinin Değerlendirilmesi, Ankara Barosu Dergisi, 2016/4, pp.45-71.

7 Prior to the amendment, the executive body was composed of a cabinet responsible for the parliament and the head of state. With the amendments to Article 8 of the Constitution, the executive body shall have the power of the Executive Committee in force. In the following parts of the study, TC instead of Turkish Constitution, TCC for Turkish Constitutional Court and finally Art. instead of Article abbreviations will be used.

8 In some cases it is called as single executive system. Anayurt, Ömer, and Ahmet Ekinci; Tek Yapılı Yürütme Esasına Dayalı Hükümet Sistemlerinde Başkan Yardımcılığı Kurumu ve 2017 Anayasa Değişikliği İle Getirilen Sistemde Cumhurbaşkanı Yardımcılı̆̆ı Kurumu Üzerine Karşılaştırmalı Bir Analiz, Zafer Gören Armağanı, 2017, pp. 440-500.

9 Before amended the Art. 8 of the TC was regulated that "Executive power and function shall be exercised and carried out by the President of the Republic and the Council of Ministers in conformity with the Constitution and the law". 
the Turkish presidential system included a form of Latin America's hyper presidential type ${ }^{10}$. Subsequently, it is not easy to define the system literally as presidential-parliamentary, as specified by Shugart \& Carey, or in the form of the super presidentialism established by Fish ${ }^{11}$, which are the systems for presidents with solid powers.

This study will assess how the new Turkish system differs from pure presidential cases compared to the stable pure presidential system elements. In addition, the term hyper presidentialism is often used for describing the new Turkish governmental system. Hyper-presidentialism is a form of presidential system where presidents enjoy extreme powers primarily free from the constitutional restrictions encountered in certain Latin American, African or Asian cases ${ }^{12}$. Özsoy Boyunsuz studied the new system, which could be regarded as an example of hyper-presidentialism and contrasted with other types of presidentialism. This study was made when the new system was proposed, and, as it is claimed, the system has evolved significantly into hyper-presidentialism since then ${ }^{13}$.

Briefly, this study will present hyper-presidentialism, presidential systems and the measurement of the President's powers in the Turkish presidential system. Pure presidentialism can be compared with the examples considered as hyper presidentialism in the literature. The most remarkable way to compare the form of governments is to measure the powers of heads

10 Nevertheless, responsible cabinet formation has been superseded since 2017's constitutional amendment and the execution has become single. Consequently, executive power and function "shall be exercised and carried out by the President in conformity with the Constitution and laws" were adopted in the Turkish Constitution recently. Boyunsuz, Özsoy, Şule, The AKP'S proposal for a "Turkish type of presidentialism" in comparative context, Turkish Studies, 17(1), 2016, pp. 68-90. p. 72 ff.

11 Fish, M. Stephen, The Impact of the 1999-2000 Parliamentary and Presidential Elections on Political Party Development, Hesli, V. L., Hesli, V. L., Reisinger, W. M., \& Kennedy, S. J. (Eds.), The 1999-2000 Elections In Russia: Their Impact And Legacy, New York, Cambridge University Press, 2003, pp. 186-212.

12 Özsoy Boyunsuz, 2016, p. 70.

13 As claimed in the study, the new system resembles a hyper presidentialism, a misleading style of the presidentialism. In fact, the originators of this new Turkish-type presidential system have declared new constitutional amendments to transform the system into pure presidentialism and increase the powers of the parliament to the public. Boyunsuz, Özsoy, 2016, p. 68 ff. Also see Cumhuriyet Gazetesi, Erdoğan'ın Gündeme Getirdiği Yeni Anayasada Cumhur'un Tavrl Netleşiyor, 05 Şubat 2021, https://www.cumhuriyet.com.tr/haber/erdoganin-gundeme-getirdigi-yeni-anayasadacumhurun-tavri-netlesiyor-1811419. 
of state ${ }^{14}$. There are different measurements in the literature. Although these measurements practise diverse elements, they serve to distinguish the governmental systems and reveal the relationship between democracy and the stability of the governmental system. For these reasons, it is necessary to present the definitions of pure presidentialism and hyper-presidentialism and their main elements. Since it is a new system, it would be convenient to compare the powers of the presidents of state in the Turkish-type system with the powers of the presidents in the hyper- presidentialism cases. However, it is not possible to study this issue deeply merely with an article.

It does not seem easy to conclude by using the institutional elements to separate pure presidentialism from hyper-presidentialism. It may not be possible to compare these two forms in the first place since hyperpresidentialism is a regime rather than a form of the governmental system. Considering this aspect, the notion of hyper ministry can be preferred to define the system. In addition, a portrait can be drawn by comparing the powers of the President in the pure presidential and hyper presidential examples with the powers of the new system of government in Turkey. One of the main differences between these two systems is the effectiveness of checks and balances. Today's system is based on the merge of superior executive power, which results from direct action to weaken other institutions, overcome institutional checks and balances, and extend presidential authority beyond previous boundaries ${ }^{15}$. Since a solid and single-structured executive is created with the new system, the status of the legislative organ within the system is significant. It is therefore convenient to define the system with legislativeoriented elements. Under the new Turkish type presidential system, the position of prime minister was removed, and the President solely became the head of the executive branch, besides being the head of state ${ }^{16}$. However, the

14 In this context the first study was carried out by Prof. Dr. Şule Özsoy Boyunsuz in 2007 in Turkey. Author basically examined the allegation that the transition to a parliamentary with president system was made with the constitutional amendment made in 2007 in Turkey. Özsoy Boyunsuz, Şule, Başkanlı Parlamenter Sistem, Gözden Geçirilmiş 2. Baskı, 2014, Onikilevha Yayıncılık, İstanbul.

15 See the comments of the study of O'Donnell since hyper presidentialism explained with the concept of delegative democracy. Larkins, Christopher Michael. The Legacies of HyperPresidentialism: Executive-Judicial Relations, Constitutional Cultures, and the Future Of Democratic Governance in Argentina and Peru, University of Southern California, 1998, p.5 ff. O'Donnell, Guillermo. Delegative Democracy, Journal of Democracy, N.1, 5, 1994, pp. 55-69.

16 Turkey's new presidential system, Strategic Comments, 2018, 24:6, v-vi, DOI:10.1080/13567888.2018.1508950, p. 1. 
power of the legislature, which is one of the bodies of the state at the same rate as the President's empowerment, has been reduced. As pointed out, governmental systems are well-defined based on the formation of executive and legislative organs and their powers and positions against each other, all of which are institutional and constitutional characters ${ }^{17}$. To clarify the frameworks of the new regime, the study will focus on the questions that analyse the regime through using the survey in the study by Fish and Kroenig in Turkey ${ }^{18}$.

Those who have followed these amendments have claimed that this governmental system will contribute to Turkey's robust executive, robust state, and sustainable democracy design. At the end of the study, the powers of the dominantly executive and influential President were compared to other strong presidential models. This aimed to reach a fundamental conclusion about the democratic level of Turkey together with the principles in comparison with other countries.

\section{A Cracked Bell Can Never Sound Well: Presidentialism to Hyper-Presidentialism}

It is accepted that naming the new system in Turkey with a stable system of government is a blind alley. The literature has acknowledged the system as hyper-presidentialism or delegated democracy. So the first need is to clarify presidential and hyper-presidentialism elements to reveal systems that deviate from presidentialism. The analysis of the governmental system can be explained in a better way by showing not only the definition but also the essential elements that describe the system.

Lijphart defines the presidential system as not dependent on legislative confidence but rather retained for a fixed term, elected by popular vote, and a one-person executive vote format ${ }^{19}$. According to the elements of the classic

17 Özsoy Boyunsuz, 2016, p. 71.

18 Fish, M. P., \& Kroenig, M. The Handbook of National Legislature, (1 Ed.), Cambridge: Cambridge University Press, 2009, pp. 685-691.

19 Lijphart compare parliamentary and presidential system. He clarified the major preferences of the presidentialism such as; the head of government is elected for a constitutionally prescribed period and in normal circumstances cannot be forced to resign by a legislative vote of no confidence (although it may be possible to remove a president for criminal wrongdoing by the process of impeachment); presidents are popularly elected, either directly or via a popularly elected presidential electoral college; presidential systems have oneperson, noncollegial executives since the members of presidential cabinets are mere advisers 
example of presidential systems are as follows; President in a position to dominate the executive and the legislative body are elected directly by the people for a fixed period with separate elections. Thus, they both have democratic legitimacy ${ }^{20}$. Secondly, the President and the legislature have no power to end each other's term in office, ensuring maximum executive stability and harmony within the executive ${ }^{21}$. It means there is certain independence in maintaining this task as well as taking office ${ }^{22}$. Thirdly, a presidential system is a form of government in which a head of government leads an executive branch separate from the legislative branch in systems that use separation of powers. The head of government is not responsible to the legislature, which cannot in normal circumstances dismiss it. Such dismissal is probable, however, in uncommon cases, often through impeachment.

The U.S. example is generally accepted as a pure presidential regime in many scholars. On the other hand, the models that do not consist of the particular elements are described as "adapted", "degraded", and "hybrid" presidential systems and are usually found in Latin America and Africa ${ }^{23}$. Until these types of hybrid presidential regimes are defined, structures similar to super presidentialism have been discussed to show presidents powerfully. The most powerful presidents are still seemed to have their government based around super presidentialism. Many authors pointed out that Weimar Germany and Russia as cases of super presidential or president-parliamentary systems $^{24}$. This government structure has been characterised as a

and subordinates of the president. Lijphart, Arend, Patterns of Democracy: Government Forms and Performance in Thirty-Six Countries, 2nd edition, Yale University Press, 2012, p. 106-108.

20 Özsoy Boyunsuz, Şule, Siyasi Parti Sistemlerine Göre Başkanlık Rejiminin Türleri, Amme İdaresi Dergisi, Volume 49, Number 3, Eylül 2016, pp.1-40, p. 4-5. Shugart \& Carey stated 4 elements to define the presidential system. These are the popular election of the chief executive; the terms of the chief executive and assembly are fixed, and are not contingent on mutual confidence; and the elected executive names and directs the composition of the government and lastly the president has some constitutionally granted law-making authority. Shugart, Matthew Soberg and John M. Carey. Presidents and Assemblies: Constitutional Design and Electoral Dynamics, Cambridge University Press, 1992, p. 15.

21 Özbudun, Ergun; Presidentialism vs. Parliamentarism in Turkey, Policy Brief, July 2012, 01, pp. 1-4, p.3.

22 Özsoy Boyunsuz, Eylül 2016, p. 4-5.

23 Özsoy Boyunsuz, 2016, p. 71.

24 In Shugart \& Carey's study the system named with president-parliamentary, and the characteristics of the system are as follows; "the popular election of the president; the 
constitutional system with a weak legislature against a well-known president with extraordinary powers. Also, it is affirmed that it has been engaged in some Central Asian Republics and some South American countries at this time $^{25}$. A structure of executive power dominates all other state offices in terms of intensity and the resources it consumes. Fish has termed systems with a president with powerful powers as super presidentialism. This system can be compared with presidential system, since the legislative and executive members are elected separately. Nevertheless since it has a dual executive structure, it can also be compared to the parliamentary system. In any case, it differs from the new form of government due to this institutional feature, since the executive is single-structured in Turkey. However as a president with strong powers is illustrated, it is necessary to point to his definition.

According to Fish, super presidentialism is described by the following features; "a president who enjoys decree powers; a president whom de jure or de facto controls most of the powers of the purse; a relatively toothless legislature that cannot repeal presidential decrees and enjoys scant authority and/or resources to monitor the chief executive; provisions that render impeachment of the president virtually impossible; and a court system that is controlled wholly or mainly by the chief executive and that cannot in practice check presidential prerogatives or even abuse of power" ${ }^{26}$. However, this type of system is different from Turkey's executive organ. Therefore, it needs to be excluded to define the system of government in Turkey.

A system with the powerful president ever defined the presidentparliamentary, or super presidentialism is dissimilar from the Turkish-type presidential system in terms of institutional elements. The significant feature is the "primacy of the president, plus the dependence of the cabinet on parliament"27. Apart from this institutional dissimilarity, Turkish

president appoints and dismisses cabinet ministers; cabinet ministers are subject to parliamentary confidence and the president has the power to dissolve parliament or legislative powers, or both" Shugart \& Carey, 1992, p. 24.

25 Gönenç, Levent, Hükümet Sistemi Tartışmalarında Başkanlı Parlamenter Sistem Seçeneği, Güncel Hukuk, S.44, 2007, pp.39-43, p. 40. Gönenç, Levent, \& Kontac1, Ali Ersoy, 2017 Tarihli Anayasa Değişikliği Sonrasinda Yasama - Yürütme İlişkileri, TBB Dergisi, N. 145, 2019, pp. 54-79, p. 62.

26 Fish, 2003, p. 200. Ishiyama, John T.; Kennedy, Ryan, Superpresidentialism and Political Party Development in Russia, Ukraine, Armenia and Kyrgyzstan, Europe-Asia Studies, Vol. 53, No. 8, 2001, pp.1177-1191, p. 1178.

27 Shugart \& Carey, 1992, p. 24. 
presidentialism look like the super presidential system only in terms of the degree of presidential powers. It put forward the view of the super presidential to distinguish the system from other presidential systems around the world because of the extraordinary powers of the head of the state ${ }^{28}$. Therefore, it is necessary to focus on the pure and the hyper-presidential systems, according to which we excluded super presidentialism due to the institutional features. Nevertheless, the new structure of the government has some similarities between hyper presidentialism due to the presidential powers and dominance of the president position ${ }^{29}$.

At the proposal stage of amendments, it was stated that the desired type of government in Turkey was not the pure presidential system. Özbudun has already identified that the Turkish-type system ${ }^{30}$ had significant similarities with the presidential systems in delegative democracies in Latin America. Turkish presidentialism has been chosen through the constitutional amendments, and it has been shown that these assertions were all true.

Comparing Fish's description with hyper-presidentialism elements, Özsoy Boyunsuz stated that the heads of the government "form and lead the government may shelter it from legislative control and most importantly enjoy strong decree powers to the point where they actually share law-making authority". It has been noted that Fish's definition "essentially covers many aspects of hyper-presidentialism and applies to examples of Latin American hyper-presidential systems" 31 . So as stated, hyper-presidential regimes are not exclusive to presidential systems, nor super presidentialism is not exclusive to the form of regimes with a dual executive. Hyper-presidential regimes can arise in a dual executive, and super presidentialism can be seen in single executive models ${ }^{32}$.

It is generally acknowledged that there are many variants of the presidential system. These variants are classified as separated and delegative systems. A separated presidential system rather than a highly authorised presidency, strong checks and balances, and competing executive, legislative and judiciary branches are the separated presidential system that the U.S. is a

Gönenç \& Kontac1, 2019, p. 61.

Özsoy Boyunsuz, 2016, p. 72 ff.

30 Özbudun, Ergun, Başkanlık Sistemi ve Türkiye, Analiz, Liberal Perspektif, Özgürlük Araştırmaları Der., N.1, Mayıs 2015, p. 9.

31 Özsoy Boyunsuz, 2016, p. 73.

32 Özsoy Boyunsuz, 2016, p. 73. 
well-known example of. This kind of system's constitutional branches (executive, legislative and judicial) share and compete for power and restrain each other feature are highlighted ${ }^{33}$. The new system of government does not purpose to build a pure presidential model or separated presidential system since the absence of the actual checking structure, and the leading powers merge in the President. Otherwise, there would not be speeches to encourage a pure presidential system today.

Presidential system of government has some own advantages and disadvantages ${ }^{34}$. It is clear that the disadvantages of this system will bring serious problems especially in countries with underdeveloped democracy. It is noteworthy that the system has prone to dictatorship, especially since presidents are powerful and the single authority in the executive.

In 1994, James stated there are separated presidentialism and presidencycentered systems which have different features from each other. The presidency- centered system is exemplified as another type of presidential regime, "election to the highest executive does often mean automatic power". As James points out, the President is considerably more central and dominant. President has a considerably more centrically and dominant position. President "if not commanding, role in setting the agenda and directing public policy, and he can use extensive institutional, personal, and plebiscitarian resources to dominate other institutions of government". The formal separation of powers still exists, and opposing branches do not always stand inadequately through the executive design policy. However, the separation of powers is a formality in the long run, and institutional checks and balances are weak or ineffective.

Presidency- centered systems are named highly similar to O'Donnell's delegative democracy regime, characterised by an excessive emphasis on presidentialism. Delegative democracy regime is a regime that is characterised by an excessive focus on presidentialism ${ }^{35}$. O'Donnell's explanation often stated about the characteristics of this regime is that the president "wins a presidential election that enabled the country to govern as he sees fit... for the term of office to which he has been elected"36.

33 Özsoy Boyunsuz, Eylül 2016, p. 4-5.

34 See the system of government criticisms in Mainwaring, P., \& Shugart, M. P. Juan Linz, Presidentialism, and Democracy: A Critical Appraisal, Comparative Politics, Vol. 29(4), 1997, pp. 449-471.

35 Larkins, 1998, p. 60-61.

36 See O’Donnell, Guillermo. Delegative Democracy, Journal of Democracy, N.1, 5, 1994pp. 55-69, p. 60. Larkins, 1998, p. 61. 
Delegative systems are characterised by free and fair elections, which allows for a degree of opposition. It is supposed that, this system, at any rate, acknowledges political freedom and rights. It is supposed that, the recognition of political freedom and rights can be determined to some extent in the system. Representative democracy and authoritarianism overlap within this kind of unrestrained presidentialism because other representative bodies are taken only as impairments to the executive. Presidents symbolising the national will and delegative systems depend on the idea that the President who won the election is thereby eligible to rule as they see appropriate and "constrained only by the hard facts of existing power relations and by a constitutionally limited term of office" 37 . This is strongly majoritarian rather than libera ${ }^{38}$ since organised pluralism is less developed and effective in liberal democracies, and horizontal accountability is very weak or non-existent ${ }^{39}$. The President uses powers in many areas, such as institutional and political, and the exercise of these powers includes the use of constitutional powers and all the resources of the state and, consequently dominates the entire system.

O'Donnell pointed out that delegative democracies obviously occur in many regions around the world. These type of democracies are seen in Latin American countries, where examples of hyper-presidentialism are widely found around the world. These seem mostly in Latin America where the majority of the world's hyper-presidentialism is common ${ }^{40}$. Larkin put forward that the "hyper-presidential" democracy differs from typical presidency-centered or delegative democracies since they are considered by an even greater emphasis on executive power and the great weakness of checks and balances. For personal or other reasons, presidents overcome constitutional controls and rewrite the formal and informal rules of the game in hyper-presidential democracies. Thus, while executive dominance in delegative democracies is somehow a coincidental result of particular historical or institutional factors, in hyper-presidential democracies, it is the consequence of overt action by the President to change the regime and

37 O’Donnell, 1994, p. 60 ff. Özsoy Boyunusuz, 2016, p. 71. Taş, Hakkı, Turkey - From Tutelary to Delegative Democracy, Third World Quarterly, 36:4, 776-791, 2015, DOI: 10.1080/01436597.2015.1024450, p. 776.

38 Özsoy Boyunusuz, 2016, p. 71.

39 O'Donnell, 1994, p. 61. Schmidt, Gregory D. Delegative Democracy in Peru? Fujimori's 1995 Landslide and the Prospects for 2000, Journal of Interamerican Studies and World Affairs, spring, 2000, Vol. 42, No. 1 (Spring, 2000), pp. 99-132, p. 100.

40 O’Donnell, 1994, p. 60. 
centralise power in their own hands. Özbudun discussed that "this type of democracy that fits the Turkish case very well. He declared that "Erdogan's style of leadership, particularly in his third term in office, bears clear marks of personalismo, with a strong sense of mission and an excessive concentration of authority in his hands" ${ }^{\prime 1}$ many years before 2017's constitutional amendments. Also Linz clarified in his study that there are many perils about presidentialism $^{42}$. One of them the system of government is leads the personalization of power which is a paradox of presidential government.

The principle of pure presidentialism is the separation of powers. Nevertheless, the overlapping concept of checks and balances is equally essential. Conversely, challenged presidents use the rhetoric of separation of powers to defend their actions and dispute against the imposition of checks and balances by the other branches and institutions in hyper-presidentialism ${ }^{43}$. Constitutional accountability is theoretically jeopardised and often violated due to the weakness of institutional checks and balances from the legislature, the judiciary, and other actors in delegative and presidency-centered democracies. Larkins also stated that hyper-presidentialism's primary descriptive characters are weak and primarily ineffective checks and balances. However, since there are free, fair and frequent elections and the political rights to free speech, press and association, the system may not be defined as an autocratic regime ${ }^{44}$. In such systems, "presidents often succeed in avoiding opposition in the legislature or courts through populist, plebiscitarian tactics and in accumulating personal power free from constraints" ${ }^{45}$. From the separation-of-powers point of view, having a legislative stage in enforcing administration policy is significant. The integrity of this legislative stage must be protected against encroachments, both as a matter of process and mentality of the character of other phases of governance ${ }^{46}$.

41 Özbudun, Ergun; AKP at the Crossroads: Erdoğan's Majoritarian Drift, South European Society and Politics, 19:2, pp. 155-167, 2014, p. 163.

42 Linz, Juan J.; The Perils of Presidentialism, Journal of Democracy, Volume 1, Number 1, winter 1990, p. 54, pp. 51-69.

43 Rose-Ackerman, Susan, and Diane A. Desierto; Hyper-Presidentialism: Separation of Powers Without Checks and Balances In Argentina and Philippines, Berkeley Journal of International Law, V.29, 2011, pp. 246-333, p. 247.

${ }_{44}$ Larkin, 1998, p. 60-61.

45 O’Donnell, 1994, p.60-61. Özsoy Boyunsuz, 2016, p. 72.

46 Waldron, p. 466. 
Finally, it is necessary to mention the essential elements of hyper presidentialism with noted delegative democracies. According to Larkins, the cause of hyper presidentialism emergence is "Historical, economic, and political conditions favour presidential dominance and direct action taken by the president to accumulate additional powers" ${ }^{\prime 7}$. Also, voting of executive and legislature bodies with free, fair, and competitive elections are the democratic bond of the system ${ }^{48}$. The most critical dramatic change is seen in the checks and balances mechanism with the delegative democracies. Checks and balances essentially do not exist, and the President's party might dominate the legislature, and the courts typically lack political independence in hyperpresidentialism. In delegative democracy, there may be opposition control of the legislature ${ }^{49}$. The President's influence is at the fore in the formation of public policy. Parliament often stands pointlessly, and the President creates policy by especially presidential executive decrees. According to Larkins, "even greater leeway for the President to determine the nature and direction of public policy. The judiciary either declines to review the legality of presidential: acts or explicitly upholds their legality" ${ }^{20}$. In the hybrid model, executive judicial relations are formed under the direct influence of the presidents. Larkins clarified that the "president takes direct action to limit the judiciary's independence and alter executive-judicial relations in their favour" ${ }^{\prime \prime}$. As a result, hyper-presidentialism is accepted as a form of delegative presidency. As described in the literature, hyper-presidentialism can be a democratic form if it conforms with representative democracy; on the other hand, super-presidentialism is a system that cannot be applied to any kind of democratic system ${ }^{52}$.

47 Delegative democracies only occur with historical, economic, and political status favor presidential dominance. Larkins, 1998, p. 67.

48 In delegative democracies, the democratic connection is the same.

49 Larkins stated that the opposition may control legislature organ, "the military may be autonomous, and the courts may have, some independence. However, the weakness of these institutions makes them ineffective sources of checks and balances". Larkins, 1998, p. 67.

50 This may be different in a delegative democracy since there is a small amount opposition. Despite regular opposition in parliament, courts, or among the public a broad margin for the President to determine the nature and direction of public policy. This is accomplished by issuing constitutional or "emergency" decrees. Larkins, 1998, p. 67.

51 Instead of hybrid democracies, "the judiciary's institutional weakness indirectly favors the president" in delegative democracies. See the details Larkins, 1998, p. 67.

52 This topic is underlined by Özsoy Boyunsuz such as what matters in this difference is whether Dahl's six criteria fit the representative democracy, regardless of the name of the system. Özsoy Boyunsuz, 2016, p. 74-75. See Larkins comments Larkin, 1998, p. 67 ff. 
As Özsoy Boyunsuz (2016) portrayed that it is not possible to talk about pure presidency in the existence of a president who directs the legislature and the judiciary and is empowered with excessive powers. Since, democratic control and balance are weakened in these systems. Such presidential regimes are characterized as "presidentialist" (Tezic, 2013), "delegated" (O'Donnell, 1993), "hyper - presidentialism" systems as an extreme type of delegated presidential systems (Larkin, 1998) or "super presidentialism" (Fish, 2005) (Özbudun, 2012) ${ }^{53}$. Furthermore it is mostly discussed in the literature is presidentialism comprehends a variety of systems of government. The most important thing is the variations within presidentialism. As Mainwaring and Shugart discussed before "presidential systems vary and their dynamics change considerably according to the constitutional powers of the president, the degree of party discipline, and the fragmentation of the party system" ${ }^{24}$.

Regardless of whether the new form of government in Turkey is recognized as hyper-presidentialism or not, the important issue is that it weakens democratic institutions and causes them to become unstable and ineffective. Whether the new system of government can be named hyperpresidentialism or not, it is consequently essential to weaken democratic institutions and eliminate democratic stability and effectiveness. Nevertheless, it has been proven that the Turkish presidential system was adapted with the delegative/hyper-presidentialism model from the constitutional characters of amendments before the system took effect ${ }^{55}$. Nowadays, since the application

53 Özsoy Boyunsuz cited Özbudun, Ergun; Türk Usulüne Göre Başkanlık Rejimi, http://www.milliyet.com.tr/turk-usulune-gore-

baskanliksistemi/gundem/gundemyazardetay/15.12.2012/1641997/default.htm

(04.07.2015). Teziç, E. (2013), Anayasa Hukuku, Beta, İstanbul, 2013. Fish, S. Democracy Derailed in Russia the Failure of Open Politics, Cambridge University Press, Cambridge, 2005. Özsoy Boyunsuz, Şule, Siyasi Parti Sistemlerine Göre Başkanlık Rejiminin Türleri, Amme Idaresi Dergisi 49.3 (2016), pp.1-39, p.8.

54 Mainwaring \& Shugart, 1997, pp. 449-471. Esen, Berk \& Gumuscu, Sebnem; The Perils of "Turkish Presidentialism", Review of Middle East Studies, Middle East Studies Association of North America (MESA),Vol. 52, No. 1, Apr1l 2018, pp. 43-53. Linz, Winter 1990, pp. 51-69.

55 Özsoy Boyunsuz is identified through these key features of the system. First and one of vital feature is absence of constitutional checks and balances on the presidential powers. There is a highly empowered president however the legislature and judiciary organs are considerably weak. The constitution amendment does not offer separations of powers with including such dissolution of assembly, parliamentary immunity for ministers, and exclusive executive control over initiating budged proposals in order to empower executive authority. The proposed model is not offered a pure presidentialism. Özsoy Boyunusuz, 2016, p. $70 \mathrm{ff}$. 
accompanies this, it is seen that it is very appropriate to call the system with such a naming. Several evaluations are made regarding pure presidential systems and the relationship between democracy and the system's stability. It is emphasised that stability and the success of the system depend on many differences ${ }^{56}$.

\section{The Emergence of Turkish Type Presidentialism}

Presidential system requests were not the emergence of a new claims system in Turkey ${ }^{57}$. The transformation in the government of Turkey began in 2007 through constitutional changes. Since then, Turkey has been subjected to a more rationalistic parliamentary system, and the President has become more powerful ${ }^{58}$. Until 2007's constitutional amendment, the President was elected by two-thirds of the majority of the parliament, rather than the people ${ }^{59}$. However, Özbudun stated, with the constitutional amendment of 2007 , the system of government was brought one step closer to a semipresidential system ${ }^{60}$. In 2014, the head of state elected by the people entered the Turkish political system for the first time. With this election, the system has become so-called parliamentary with a "president" system ${ }^{61}$. These developments are mainly the starting point of the demands for the presidential system. Soon, the regime's transformation, in practice, continued to link the

56 Özsoy Boyunusuz, 2016, p. 71.

57 These requests were addressed by Turgut Özal and Süleyman Demirel previous heads of state, but no concrete steps were taken. The leader of the Justice and Development Party (AKP) who voiced the most powerful presidential system demanded and offered a constitutional amendment proposal. Recep Tayyip Erdoğan, the current head of state and the leader of the ruling political party, the AKP. The constitutional amendment proposal was submitted to the Constitutional Reconciliation Commission (CRC) at the parliament and set the agenda of the discussion. Ataay, Faruk, Adalet ve Kalkınma Partisi'nin 'Başkanlık Sistemi' Önerisi Üzerine Değerlendirme, Alternatif Politika, December 2013, pp. 266-294, p. 269.

58 Özsoy Boyunsuz was evaluated over the powers of the president with the amendments of this period. Her study is also important in terms of demonstrating the capacity of presidents to exercise authority in Turkey. Özsoy Boyunsuz, 2014.

59 The well-known "367 crisis" experience surfaced the way for the proposed amendment, the AKP's constitution in 2007. Therefore, constitutional amendments (Law No 5678) of the Republic of Turkey Constitution, was accepted on 31 May 2007. In the occurrence of the new constitution, the CRC that was established before and has worked since 2013 stopped operating. The emergence of constitutional amendments and for constitutional claims see. Özsoy Boyunsuz, 2016, pp. 68-90.

60 Özbudun, July 2012, p.2.

61 Gönenç, 2007, pp.39-43. 
President's party to the AKP government; the system served as a semipresidential system.

During that period, President Erdogan noted that the current structure has already become a de facto presidential system, so a constitutional amendment must be made to align the law with the actual situation. President Erdogan was alleged to the changes in the actual situation, to the necessity to adapt the law and the Constitution to the actual situation in Turkey. While the President's connection with his party continued organically but not legally, the sustainment of the organic bond with the political party showed that the system was operating with a different regime de facto. At that time, the mechanisms associated with the confidence vote, such as the formation of the cabinet and the overthrowing of the government, found in the Constitution, were regulated as specific to the parliamentary system. However, Prime Minister Davutoğlu was dismissed due to party relations, and a new prime minister was appointed to replace him. Although, the formation of the cabinet, the election of ministers, the mechanism, and the vote of confidence are in force with specific to the parliamentary system principles in the constitution. The de facto situation is not legal because, during that time, Article (Art.) 101 of TC stated that 'If the President-elect is a member of a party, his/her relationship with his party shall be severed and his/her membership of the Grand National Assembly of Turkey ${ }^{62}$ shall cease'. Although this article was amended by the first group of 2017's constitutional changes, one of the most important illustrations of the actual situation is the resignation of Prime Minister Ahmet Davutoğlu following the meeting of President Erdoğan at that time $^{63}$. Therefore, the head of state effectively dismissed the prime minister even though it was not included in the Constitution.

While the constitutional amendments removed the parliamentary system, it did not introduce a presidential system that can function in a democratic regime, as Esen pointed out, which addresses the new system's constitutional amendments in many dimensions in a comparative study ${ }^{64}$. The AKP continued to repeat these demands. However, the 24th general election, which took place on 7 June 2015, was held with hung parliament. Failed attempts to

62 Turkish Parliament, Turkish Assembly or parliament phrases will be used in the study. The Grand National Assembly of Turkey's abbreviation is known as TBMM. See https://global.tbmm.gov.tr/.

63 Gözler, Kemal, 1982 Anayasası Hâlâ Yürürlükte mi? Anayasasızlaştırma Üzerine Bir Deneme (Versiyon 4), 30 May1s 2016, Retrieved Ocak 2017, 01, from $\mathrm{http} / / / w w w . a n a y a s a . g e n . t r / a n a y a s a s i z l a s t i r m a-v 4 . p d f$.

64 Esen, 2016, pp.45-71. 
form a coalition government resulted in a snap general election being called for November 2015. President Erdogan has presented this situation to the public as an indicator of the need for a single headed execution. According to him, the country has a de facto presidential system, but it must become legal with constitutional changes. As the current power of the AKP continued to repeat these demands, President Erdoğan stated that the country's de facto was already a presidential system; however, could not establish a government in the 7 June elections before the constitutional amendments to a more severe expression of these demands ${ }^{65}$. The majority in parliament of AKP could not adopt constitutional amendments alone ${ }^{66}$.

The first study evaluating the system of government measurement of the President's powers was led by Özsoy Boyunsuz. She compared the parliamentary system with President and semi presidentialism by scoring and measuring the powers of the President ${ }^{67}$. Another analysis was carried out by Gönenç and Kontac1, where powers of the heads of state were measured to identify the system. The authors have revealed a shift from the pure parliamentary model to the solid presidential model with the constitutional amendments ${ }^{68}$.

It was asserted in many discussions that it would not be appropriate to turn towards the presidential, super-presidential or hyper-presidential system because of its multi-party and disciplined party structure. In such a system, it was emphasised that it would not be possible to agree, and political polarisation and a stressed environment would arise since the person winning the presidential election would gather all the power ${ }^{69}$. Also, this system could create a significant hazard due to the democratic regime. It has been and is

65 Özsoy Boyunsuz, 2016, p. 70-71.

66 Tahmazoğlu Üzeltürk, Sultan, Anayasa Değişikliğinde Cumhurbaşkanı, Güncel Hukuk, Şubat 2017, pp. 12-14.At this point, he received the support of one of the right-wing parties, the MHP. The proposed amendment to the constitution is quite comprehensive and will certainly be a model of the presidential system. The negotiations between the two parties have begun without the constitutional amendment being made public. The proposal for a wide-ranging constitutional amendment following the agreement of the two parties presented to the Parliament since the proclamation of the Republic in 1923 among the Turkish constitutions such as; a powerful president has emerged for the first time of the Turkish Republic.

67 Özsoy Boyunsuz, 2014, p.298 ff, 337 ff.

68 Gönenç, \& Kontac1, 2019, pp. 54-79.

69 Uluşahin, Nur; Anayasal Bir Tercih Olarak Başkanlık Sistemi, Yetkin Yayınları, Ankara, 1999. 
still being emphasised that Turkey might achieve stable and effective governments only through rationalising the parliamentary system ${ }^{70}$.

In an analysis performed when the amendments were at the proposal stage, Esen emphasised that some of the authorities granted to the President were at the level higher than in Latin American presidential systems, where the legislative and judicial organs are weak, but the President is powerful. It was determined in that analysis that the democracies in Latin America still have their significantly vulnerable or delegative character ${ }^{71}$. In other words, the so-called presidential model has not brought "democracy" with it.

\section{Main Features of Brand New Turkish Type of Presidentialism}

There is a consensus that the separated democracies presuppose a definite separation in legislative and executive capacity that cannot end each other's existence. Pure presidentialism or separated democracies is based on the idea of "maximum separation of powers and full and exclusive responsibility of the cabinet to the president" 72 . The separation of powers that defines presidentialism implies a relationship of mutual independence between the executive and the legislature, contrasting with mutual dependence that is acknowledged to characterise executive-legislative relations under the parliamentary system ${ }^{73}$. However, the constitutional amendments do not precisely envisage this definite separation. Instead, maximum separation is intended "to ensure that each branch could impose checks on the other without fear of jeopardising its existence," $" 74$ and that is characteristic of presidentialism ${ }^{75}$. The scoring of the powers granted to the presidents of different regimes based on these criteria makes it possible to locate them in a two-dimensional space.

70 Onar, Erdal; Türkiye'nin Başkanlık veya Yarı-Başkanlık Sistemine Geçmesi Düşünülmeli midir? Başkanlık Sistemi içinde, Teoman Ergül (Ed.), Türkiye Barolar Birliği Yayınları, Ankara, 2005, pp. 71-103. Gönenç, Levent; Türkiye'de Başkanlık Sistemi Tartışmaları, Güncel Hukuk, Haziran, 2011, pp. 14-16, p.11-12. Serap, Yazıcı; Başkanlık Sistemleri: Türkiye İçin Bir Değerlendirme, Başkanlık Sistemi içinde, Teoman Ergül (Ed.), Türkiye Barolar Birliği Yayınları, Ankara, 2005, pp. 125-145.

71 See fragile democracies, Kontac1, Ali Ersoy; Kurılgan Demokrasilerde Siyasal Örgütlenme Özgürlüğ̈̈, Savaş Kitapevi, Ankara, 2016.

72 Shugart, \& Carey, 1992, p. 15.

73 Cheibub, J.A. Presidentialism, Parliamentarism, and Democracy, Cambridge University Press, USA, 2007, p. 7.

74 Shugart \& Carey, 1992, p. 19.

75 Metcalf, Lee Kendall, Measuring Presidential Power, Comparative Political Studies, V.33 (5), 2000, pp. 660-685, p.127. 
It declared that even in the systems defined as the pure presidential system, the forces are not subject to pure separation ${ }^{76}$. The legislative powers that affect the legislative process leading to the assertion that the forces cannot be isolated from the pure separation, such as the presidential veto or dissolution of parliament. It is better to discuss whether the current Turkish presidentialism system is an actual presidential system or not, rather than debating whether a presidential system that foresees a new governmental system is a purely presidential system or not. Also, it is worth mentioning that maintaining a stable democracy in presidential systems is less likely than in parliamentary.

As stated above, checks and balances essentially do not exist, and the President's party might dominate the legislature, and the courts typically lack political independence in hyper-presidentialism ${ }^{77}$. Therefore, basic questions from the Fish and Kroenig study will be answered to show how much the legislature dominates and defines the new system of government in Turkey. Since the study of Fish and Kroenig revealed the main characteristics with an emphasis on legislative aspects ${ }^{78}$.

Gönenç, who evaluated the system in Turkey before its implementation in terms of legislative-executive relations, analysed the individual and mutual powers of the legislature and the executive. Also, he evaluated the consequences that may arise in the practice of constitutional law ${ }^{79}$. The new adaption of the system of unique models is defined in Category 2 within a unified executive manner. Classic presidentialism was where the President was popularly elected but not accountable to the legislature ${ }^{80}$.

The Constitution provided a popularly elected president who is limited to two consecutive -five-year- terms. ${ }^{81}$ The President of the Republic is described as the head of state $^{82}$, and the President "shall ensure

76 Shugart \& Carey, 1992, p. 19.

77 Larkins, 1994, p. 67.

78 Fish, \& Kroenig, 2009, pp. 685-691.

79 Gönenç, Levent, Uygulamada Cumhurbaşkanlığı Hükümet Sistemi, TEPAV, Ankara, 2018. Retrieved from https://www.tepav.org.tr/upload/files/1526884486-7.Uygulamada Cumhurbaskanligi Hukumet_Sistemi.pdf.

${ }^{80}$ Siaroff, A. Comparative Presidencies: The Inadequacy of the Presidential, SemiPresidential and Parliamentary Distinction, European Journal of Political Research, V. 42(287), 2003, pp. 287-312, p. 294-295.

81 See Art. 101 of TC.

82 The executive power shall be vested in the President of the Republic. See Art. 104 of TC. 
the implementation of the Constitution and orderly and harmonious functioning of the organs of the State". The President can be investigated not only for crimes related to his duties, but also for any crime, but only by the Supreme Criminal Tribunal. The Constitutional Court acts as the Supreme Criminal Tribunal ${ }^{83}$. Not every conviction against the President will result in the termination of his mandate. The mandate of the President of the Republic shall end if convicted by the Supreme Criminal Tribunal for a crime that prevents from being elected as a deputy (Art. 76/2). (Art. 105/5) ${ }^{84}$. The President can only be removed from office if accused of any kind of crime "that prevents being elected shall end" by the parliament.

Fish and Kroenig ${ }^{85}$ analysed the system of Turkey in a comparative sense. The essential elements of the new regime will be expressed by using the questions from the authors' study. The first question in their work was whether the Turkish parliament could remove the President from his office or not and the criminal responsibility.

1. Without the involvement of any other agencies, the legislature alone can impeach the President or replace the prime minister ${ }^{86}$. The new governmental system does not have a prime minister. The new regime includes the deputy president and ministers, whom the President also appoints. The President appoints the deputy and ministers. Art. 104 and 106 stated that President "shall appoint and dismiss the deputies of the President of the

83 See the related sections which are the formation of the Constitutional Court.

84 According to the TC this proposal can be initiated by a motion of the absolute majority of Turkish parliament. The Parliament may decide to launch an investigation with three-fifths of the total number of its members by secret ballot after debate the motion in one month. If an investigation is decided to be launched, it shall be conducted by a committee. Committee report is discussed in parliament after a certain period of time. According to Criminal Liability of the president, Article 105 which is amended on April 16, 2017 ruled that the president be investigated on allegations of a crime by absolute majority of the parliament. Such a motion can be given to by at least 300 members of the parliament out of 600 . Furthermore, these provisions are stated in "shall also apply after the termination of the term of office of the President of the Republic to the alleged crimes to have been committed during the term of his Vher Office"

85 Fish \& Kroenig, 2009, pp. 685-691.

86 The legislature alone, without the involvement of any other agencies, could impeach the president or replace the prime minister before constitutional amendments in 2017. The parliament could remove the prime minister with a vote of no confidence. Meanwhile, impeaching the president due to treason to the State with a three-fourths majority of the vote out of total membership before the new system was adopted in 2017. For survey questions, see. Fish \& Kroenig, 2009, p. 5-13, 685. 
Republic and the ministers". Parliament can accuse the President, allegedly committing a crime with two-thirds of votes out of total membership.

The President leaves his duty only under the condition that he is convicted of a crime that prevented him from being elected as a member of parliament. However, there is no law in the Turkish regulation regarding implementing or being in force of this treason until now. The portrait of this treason had to be made by the parliament that brought the accusation, and then the accusing council had to respond to it. Before the newly adopted system, the legislature, without the involvement of any other agencies, can control the President or replace the prime minister.

Remarkably, the same crime liability principles apply to both the deputy president and the ministers who have been appointed by the President regarding their crimes-related duties ${ }^{87}$. According to Özsoy Boyunsuz, it is "highly unusual to grant parliamentary immunity to executive branch members in a presidential system where they cannot be members of the legislature and cannot vote or participate in the legislative process" 88 . Formerly, deputies might serve concurrently in ministerial positions.

Additionally, no matter what type of crime the President has committed, the Supreme Criminal Tribunal will be tried in the general courts. As conveyed by Gözler, the President will be judged by Supreme Criminal Tribunal rather than the competent and authority criminal courts ${ }^{89}$. According to general criminal jurisdiction, this judgment covered both the duty and personal crimes of the President. The Supreme Criminal Tribunal duty is carried out by the Turkish Constitutional Court (TCC) (Art. 148). The President appointed either directly or indirectly 12 out of 15 judges of the Constitutional Court (Art. 146). The tragic conclusion driven from these arrangements is the jurisdiction against the President, which belongs to the Supreme Criminal Tribunal of criminal allegations. Thus, the President will remain in office who may be convicted of any crime. This would be one of the crimes that prevent entrance to the election. The others are embezzlement,

87 TC Art. 106 declared as the parliament "may table a motion requesting that the Deputies of President of the Republic and ministers be investigated on allegations of perpetration of a crime regarding their duties".

88 Özsoy Boyunsuz, 2016, p. 82.

89 Gözler, Kemal; Türk Anayasa Hukuku Dersleri, (22nd Ed.), Bursa: Ekin Yayınevi, 2018, p. 339 . 
corruption, and bribery ${ }^{90}$. Correspondingly, the question of whether there will be a convicted president in Turkey inevitably comes to our mind.

2. Ministers may not serve simultaneously as members of the legislature. Deputies may not serve simultaneously in ministerial positions. Ministers and Vice President ${ }^{91}$ are appointed and dismissed by the President. They are politically responsible to the President.

3. The legislature does not have powers to summon over the executive branch officials; hearings testifying before the legislature or committees are regularly held. The parliament cannot interpellate officials from the executive. The authors have exemplified the Art. 98 of the T.C. It should be noted that the assembly has only a limited number of "information acquisition" instruments. Still, they do not confirm the result of supervising the execution with alteration of the article. The no-confidence and the mechanism of a verbal question with a more significant impact have been removed from the information acquisition instruments of the assembly. According to the first paragraph of the TC Art. 98, the Assembly "shall exercise its powers of obtaining information and supervision through parliamentary inquiry, general debate, parliamentary investigation and the written question"92.

90 Art. 76 of the TC is regulate the ability to be elected as a member of parliament. The President and the Vice President and the Ministers must also have the ability to be elected. In terms of the adequacy of being elected in the article. In the article, the following provisions regarding crimes that impede the ability to be elected after the conditions are counted are regulated "who are banned from public service, who have been sentenced to a prison term totaling one year or more excluding involuntary offences, or to a heavy imprisonment; those who have been convicted for dishonorable offences such as embezzlement, corruption, bribery, theft, fraud, forgery, breach of trust, fraudulent bankruptcy; and persons convicted of smuggling, conspiracy in official bidding or purchasing, of offences related to the disclosure of state secrets, of involvement in acts of terrorism, or incitement and encouragement of such activities, shall not be elected as a deputy, even if they have been granted amnesty." It should also be noted that there is no law that defines what and how is explained the meaning of the "who are banned from public service". (Gözler, 2018, p. 171).

91 Vice president's term use as deputy of the president in the Constitution. However it is possible to use both concepts in this study.

92 Art. 98 stated that "A parliamentary inquiry is an examination conducted to obtain information on a specific subject. A general debate is the consideration of a specific subject relating to the community and the activities of the State at the Plenary of the Grand National Assembly of Turkey. A parliamentary investigation is an investigation made under the paragraphs V, VI and VII of the Art. 106 concerning the deputies of the President of the Republic and the ministers". 
4. The legislature can conduct an independent investigation for both the chief and the agencies of the executive. The parliament can investigate the executive. However, as described above, to prosecute any criminal case related to the President's personal or duty, there is a need for an extraordinary majority of the parliament. This extraordinary majority of the Assembly is still needed for prosecuting the judges related to the duties of the Vice-President and ministers' duties. Having the agreement of the members of the party alongside this majority is essential. It should be noted that this will not be possible in practice since the President has now become a chair of a political party, and the President leaves his neutral position with the new amendments. Thus, the previous provision of the Constitution (Art. 101), which is "The President-elect, if a member of a party shall sever his relations with his party and his status as a member of the Turkish Grand National Assembly shall cease", has been repealed. Therefore, there is now a president with a political party and even a political party leader in Turkey.

5. The legislature does not have effective oversight over the coercion agencies (the military, law enforcement organs, intelligence services, and the secret police). The legislature lacks effective powers of oversight over the agencies of coercion. There was not a change in favour of the parliament associated with this manner. On the contrary, the oversight of the parliament on many agencies has been considerably reduced.

6. The legislature does not appoint the prime minister. The system does not comprise a prime minister. The new system consists of the deputy president and ministers, who the President appoints ${ }^{93}$. The TC (Art.104 and 106) ruled that President "shall appoint and dismiss the deputies of the President of the Republic and the ministers". The President of the Republic may appoint one or more deputies after being elected. Legislature's approval is not required to confirm ministerial and deputies of presidential appointments.

7. The legislature's approval is not required to confirm the appointment of ministers, or the legislature itself appoints ministers. The President shall appoint and dismiss the deputies of the President and the ministers (Art. 104 and 106 of the T.C.). The President may appoint one or more deputies after being elected. The President of the Republic may appoint one or more deputies

93 According to the Art. 106 of the TC "The President of the Republic may appoint one or more deputies after being elected". 
after being elected. The legislature's approval is not required to confirm ministerial and deputies of presidential appointments.

8. The country does not entirely lack a presidency, or there is a presidency, but the legislature elects the President. The President shall be elected directly by the public from Turkish citizens over forty years old who are eligible to be a representative and have completed higher education (Art. 101). With the referendum held in October 2007, the amendment was added to the TC which allowed the president to be elected by the people for the first time in Turkish constitutional history. Concerning the election of the President, the parliament lost its authority to elect the head of state ${ }^{94}$. Subsequently, a president elected by the people began to take place for the first time in Turkish constitutional history in 2014.

9. The legislature cannot vote no-confidence in the government. The legislature cannot vote no-confidence in the government in the newly adopted governmental system ${ }^{95}$.

10. The legislature is not immune from dissolution by the executive. The legislature is not immune from dissolution by the executive. The President may dissolve the Parliament without any conditions. Art.116 of the Constitution clarified that "If the President of the Republic decides to renew the elections". It is not conditional for the President to exercise the authority because "the general election of the Turkish Grand National Assembly and the presidential election shall be held together".

11. Any executive initiative on legislation does not require ratification or approval by the legislature before it takes effect; that is, the executive lacks decree power. The executive does not lack decree power. Although Fish and Kroenig stated that "the legislature can, however, grant temporary decree powers to the president to deal with specific issue areas"96, parliament was able to give the authority to issue decrees to the Council of Ministers by law, not to the President. In other words, this transfer of power occurred by law for the Parliament. Prior to the 2017 constitutional amendments, Parliament had granted the power to issue decrees to the Council of Ministers, not to the President.

94 Fish \& Kroenig, 2009, p. 687.

95 Before the 2017 amendments came into force, Art. 111 of the Constitution stipulates that the head of the constitution may require a vote of confidence from the parliament.

96 Fish \& Kroenig, 2009, p. 687. 
The new constitutional amendments have repealed this provision. Before the amendments, the President chaired the council of ministers only to declare a state of emergency and decrees to be issued in emergency cases. Nevertheless, power to issue decrees has belonged to the President in both ordinary and extraordinary periods during the state-of-emergency situations. The President does not receive authority from parliament to exercise his authority to issue decrees ${ }^{97}$.

According to the revision of the Turkish Constitution (TC) Art. $104^{98}$ there are areas where the President has the power to issue decrees which are exclusively reserved for presidential decrees ${ }^{99}$. According to the new Art. 104 and some of the other articles of the Constitution, there are areas where the President has the power to issue decrees and these areas are reserved as exclusive only for decrees. Also there are also optional areas that can be regulated by law or by presidential decrees in the new relevant articles of the Constitution. So the President can regulate by the decree or Parliament can enforce laws within these optional areas. Decisions shall not be made in the areas for which the constitution shall be regulated by the exclusive law and in

97 Art. 119 of the TC clarified that "In the event of state of emergency, the President of the Republic may issue presidential decrees on matters necessitated by the state of emergency, notwithstanding the limitations set forth in the second sentence of the seventeenth paragraph of the Article 104".

98 Art. 104 paragraph 17th stated that: "The President of the Republic may issue presidential decrees on the matters regarding executive power. The fundamental rights, individual rights and duties included in the first and second chapters and the political rights and duties listed in the fourth chapter of the second part of the Constitution shall not be regulated by a presidential decree. No presidential decree shall be issued on the matters which are stipulated in the Constitution to be regulated exclusively by law. No presidential decree shall be issued on the matters explicitly regulated by law. In the case of a discrepancy between provisions of the presidential decrees and the laws, the provisions of the laws shall prevail. A presidential decree shall become null and void if the Grand National Assembly of Turkey enacts a law on the same matter".

99 Gözler, Kemal, Türk Anayasa Hukuku Dersleri, (22 ${ }^{\text {nd }}$ Ed.), Bursa: Ekin Yayınevi, 2018 , p. 367. Based on the Constitution exclusive areas the President "appoint and dismiss the high ranking executives and shall regulate the procedure and principles governing the appointment thereof by presidential decree" (Art. 104/9). The establishment, abolition, the duties and powers, the organizational structure of the ministries, and the establishment of their central and provincial organizations shall be regulated by the presidential decree. (Art. 106/11). The functioning of the State Supervisory Council, the term of office of its members, and other personnel matters relating to their status shall be regulated by presidential decree. (Art. 108/4). The organization and duties of the General Secretariat of the National Security Council shall be regulated by presidential decree (Art. 118/6). 
the areas related to the restricted fundamental rights and freedoms ${ }^{100}$. The relevant ambiguity is revealed by the fact that the TC has not defined the exclusive law field as in Art.34 of the French Constitution. The decrees are reviewed by the TCC $^{101}$ (Art. 148).

Since it has become a law, the state -of-emergency decrees are reviewed by the TCC after they are approved by parliament. The court applies the ordinary constitutional guarantees criteria (such as Art. 13 of the TC) under the supervision of the enacted emergency decree laws, which also have an impact and application area after the state of emergency ${ }^{102}$.

12. Laws passed by the legislature are not veto-proof or essentially vetoproof; the executive lacks veto power or has veto power, but a majority in the legislature can override the veto. In advance, the parliament can "override a presidential veto by the veto power of the Constitution". Under the new constitutional amendments, the veto power is designed to be stronger than the former veto power ${ }^{103}$. Art.89 regulated that the President shall send the laws that he considers, wholly or partly, unsuitable for declaration, along with the justification, back to the parliament for reassessment in the same period. The article stated both partial and packet vetoes. In case of being partially considered inappropriate by the President, the parliament may discuss only those articles. If the parliament accepts the law sent back for reassessment without any amendment with "absolute majority", the law shall be promulgated by the President.

13. The legislature's laws are not supreme and subject to judicial review. TCC can review the constitutionality of laws and presidential decrees (P.D.) through concrete and abstract norm review (Art. 148, 150, and 152). The individual application is available in Turkey. According to this application, everyone may apply to the TCC on the grounds that one of the fundamental rights and freedoms within the scope of the European Convention on Human Rights, which the Constitution guarantees, has been violated by public authorities since 2010 .

\footnotetext{
${ }^{100}$ Gözler, 2018, pp. 369-370.

101 The abbreviation AYM refers to Turkish Constitutional Court (TCC).

${ }^{102}$ AYM, 24/7/2019, E.2016/205, K.2019/63. Ulusoy, Ali, Cumhurbaşkanlı̆̆ı Kararnameleri: Varoluşsal, Yapısal ve Hukuksal Bir Değerlendirme,Anayasa Yargısı,Vol: 37, N. 2, Aralık 2020, pp.31-66, p. 62.

${ }^{103}$ When the constitutional amendments were drafted a more qualified majority was sought to override the veto power. Özsoy Boyunsuz, 2016, p. 78.
} 
14. The legislature has not the right to initiate bills in all policy jurisdictions; the executive lacks gatekeeping authority. The legislature can initiate bills in all policy jurisdictions, but some of the policy jurisdictions belong to the President with presidential decree powers with the new amendments. As stated previous page, some exclusive areas have also been granted in terms of the President's authority to issue decrees. President issues a decree within the executive jurisdiction and based on the regulation in the TC the parliament should not enact laws in these exclusive areas. Decrees should only regulate these exclusive areas ${ }^{104}$.

15. Expenditure of funds appropriated by the legislature is not mandatory; the executive does not lack the power to impound funds appropriated by the legislature. The executive does not lack the power to impound funds appropriated by the legislature. Art. 161 states that presidents shall submit a budget bill to the parliament at least seventy-five days before the beginning of the financial year. The budget bill shall be debated at the Committee on Budget in the Parliament. However, if the budget law cannot be put into force within the due period, the provisional budget law shall be enacted by the parliament. If the provisional budget law cannot also be enacted, the budget of the previous year shall be applied increasingly as the revaluation rate until the President adopts the new budget law. However, concerning the budget, the law will be enacted by the parliament. If the budget is not approved on time and the provisional budget law is not adopted, the President shall be applied increasingly as per the revaluation rate until the new budget law is adopted for an indefinite period. The influence of the legislative body on the budget proposal is reduced. The parliament has been neutralised. The legislature has been forced to comply with the President in a way that can be ineffective.

16. The legislature controls the resources that finance its internal operation and provide for the perquisites of its members. As authors stated in their study, Art. 86 of the Constitution is not change by the amendments; therefore, the legislature enjoys financial autonomy, including control over members' salaries ${ }^{105}$.

17. Members of the legislature are immune from arrest and/or criminal prosecution. Fish and Kroenig stated that the 2017 constitutional amendments

${ }^{104}$ See Note 99.

${ }^{105}$ Fish \& Kroenig, 2009, p. 688. 
had not amended this provision. Authors cited that deputies are immune "with the common exception for cases of flagrante delicto", here expressed as "caught in the act of committing a crime punishable by a heavy penalty"106. However, there is a need for adding another statement at this point.

One of the exceptions to the legislative immunity is the situation in Art. 14 of the Constitution. Art.83 is identified that a representative who is supposed to have committed an offence before or after election shall not be detained, interrogate, arrested, or tried unless the parliament decides vice versa. However, this rule shall not apply in cases "where a member is caught in flagrante delicto requiring heavy penalty and in cases subject to Art. 14 of the Constitution as long as an investigation has been initiated before the election". Nevertheless, Art. 14 refers to some "situations" and not "crimes". Besides, this article sets out the prohibition of abuse of fundamental rights and freedoms.

18. All members of the legislature are elected; the executive lacks the power to appoint any legislature members. The Turkish parliament is monocamerlism, so all members of the legislature are elected by universal suffrage. The Turkish Assembly has 600 deputies elected by universal suffrage. With the constitutional amendments, the number of deputies has been increased from 550 to $600^{107}$. Increasing the number of deputies does not arise from any societal inevitability; it is a choice of political power. Since Art. 80 of the Constitution stated that the deputies "shall not represent their constituencies or constituents, but the nation as a whole".

19. The legislature alone, without the involvement of any other agencies, cannot change the Constitution. The powers of the constitutional amendment have been shared among the legislative, executive, and public. Parliament can alter the constitution with the approval of the President. As stated by Fish and Kroenig, "if the president objects to a constitutional amendment that the legislature has passed, he or she can choose to put the amendment to a nationwide referendum" 108 . It is the subject of an open and referendum on the laws on the amendment of the President.

\footnotetext{
${ }^{106}$ Fish \& Kroenig, 2009, p. 688.

107 Art. 75. Parliament "shall be composed of six hundred deputies elected by universal suffrage". Article amended several times; amended on May 17, 1987; Act No. 3361, on July 23, 1995; Act No. 4121 and lastly April 16, 2017.

${ }^{108}$ Fish \& Kroenig, 2009, p. 689.
} 
20. The legislature's approval is necessary for the declaration of war. It has been stated that the legislature's approval is essential for presidential war declarations, with the typical exception for cases of foreign incursion ${ }^{109}$. According to the Constitution, the parliament has the authority "to decide to... declare war". (Art. 87) "The power to authorise the declaration of a state of war in cases deemed legitimate by international law" is also vested in the parliament. (Art. 92) The President shall decide on the use of the armed forces of Turkey (Art. 104). In the realm of war, if the nation is subjected to unexpected armed violence, while the parliament is postponed or in retreat and thus becomes authoritative to instantly decide on the use of the armed forces, the President can decide to use the armed forces. (Art. 92/2)

21. The legislature's approval is necessary to ratify treaties with foreign countries. In the wording of Art. 90 of the Constitution, the parliament's approval is compulsory to confirm international treaties on the most significant issues. However, international contracts under some conditions may not need the approval of the parliament. ${ }^{110}$ According to Art.104, the president "shall approve and transmit international agreements".

22. Authors explored the powers of parliament to amnesty and pardon as $22^{\text {nd }}$ and $23^{\text {rd }}$ elements ${ }^{111}$. And $23^{\text {rd }}$ question is related to amnesty and pardons. The parliament has the power to grant amnesty and pardon. One of the duties and powers of the Turkish Parliament is to proclaim amnesty and pardon (Art.87).

24. The legislature does not review and does not have the right to reject appointments to the judiciary, or the legislature itself appoints members of the judiciary. No. The President and members of the courts make legal appointments, and the appointments do not require the legislature's approval. Consistent with the Constitution, the President shall also exercise powers of election and appointment and perform the other duties conferred on him/her by the Constitution and laws. (Art. 104). Among the President's most important appointments and election powers is undoubtedly his appointment to the judicial body. In general, judicial appointments are made by the President and members of the judiciary. The appointments do not require the legislature's approval.

\footnotetext{
${ }^{109}$ Fish \& Kroenig, 2009, p. 689.

${ }^{110}$ Art. 90 of TC. Current version of Constitution of the Republic of Turkey including latest amendments 08.05.2017, Constitution of the Republic of Turkey, Law Number: 2709, Date of Enactment: 18.10.1982http://www.judiciaryofturkey.gov.tr/Current-version-of-Constitution-of-the-Republic-of-Turkey--including-latest--amendments.

111 The answers to questions 22 and 23 in the Fish and Kroenig study are given together here.
} 
Art. 146 of Constitution with the amendments 2017, one of the vital appointment duties of the President is to select judges for the Constitutional Court of Turkey. The number of judges of the Court has been reduced from 17 to 15 . The General Assembly of the Constitutional Court decided to terminate the duties of two judges. The decision was made under the provisions of the Emergency Decree-Law No. 667. So, after amendments in 2017, the Court shall be composed of fifteen members. Three members of the court are elected with a qualified majority from the recommendations of certain authorities by the parliament. ${ }^{112} 12$ out of 15 members are appointed indirectly (among the three candidates proposed by the high courts for each vacant position) or directly (4 members) by the President ${ }^{113}$.

President also appointed the Chief Public Prosecutor and the Deputy Chief Public Prosecutor of the High Court of Appeals for four years. ${ }^{114}$ The High Court of Appeals is the last instance for reviewing decisions and judgments given by civil courts that are not referred by law to other civil judicial authorities. It shall also be the first and the last instance of court for dealing with specific cases prescribed by law (Art. 154).

The President's other judicial appointing powers are to appoint one-fourth member of the Council of State (Danıştay) ${ }^{115}$. As a higher judicial organ the Council of State is the "last instance for reviewing decisions and judgments given by administrative courts and not referred by law to other administrative courts".

Council of Judges and Prosecutors compose of thirteen members; shall comprise two chambers. The President of the Council is the Minister of Justice. The Undersecretary to the Ministry of Justice shall be an ex-officio member of the Council. (Art. 159). Minister of Justice appointed only by President and minister is responsible to the President. The President also appoints four members of the Council of Judges and Prosecutors. Together

112 Art. $146 / 1$ of TC.

113 See the Art. 146/3 of the TC for appointment powers of the President to the TCC.

114 The appointments will be perform from among five candidates nominated for each office by the General Assembly of the High Court of Appeals from among its own members by secret ballot. They may be re-elected at the end of their term of office. (Art. 154)

115 According to the TC "Three-fourths of the members of the Council of State shall be appointed by the Council of Judges and Prosecutors from among the first category administrative judges and public prosecutors, or those considered to be of this profession; and the remaining quarter by the President of the Republic from among officials meeting the requirements designated by law" (Art. 155/3). 
with the Minister of Justice, who is the chairman of the Board, five out of the 13 members are determined by the President.

25. The legislature does not appoint the chair of the central bank. The President appoints the governor of the Central Bank of the Republic of Turkey. Before the constitutional amendments, the government appointed the chair of the Central Bank. In the process of a constitutional amendment, the provision in the law on the appointment of the chair of the central bank has been repealed by the Decree no. 703 introduced by the Council of Ministers of the period and adopted by the Parliament. ${ }^{116}$ The President appoints the Central Bank's chair and deputies. It was determined by presidential decree at the time, right after the new regime came into force, and the President took office with the Presidential Decree "Appointment Procedures in Public Institutions and Institutions with Senior Public Administrators" of 10 July 2018. This decree specifies the procedures and principles of the President's appointments to important offices in the administration and ministers ${ }^{117}$.

26. The legislature has a powerful voice in the operation of the Radio and Television Supreme Council. The Council established for regulation and supervision of radio and television activities comprises nine members. The members are elected, based on the number of members allocated to each political party group, by the Plenary of the parliament from the candidates, twice the number of which is nominated by political party groups in proportion to their number of members. (Art.133). Authors also underlined the power of media especially stated own media ${ }^{118}$. The Turkish Radio-Television Corporation is one of main stated owned media in Turkey. The Director General and Board Members of Radio and Television Corporation are appointed by the President according to revised wording of the Law of Turkish Radio and Television no. 2954 and Presidential Decree No. $3^{119}$.

27.In this part the continuance of the assembly is examined. In this context it has been investigated whether the assembly is meeting regularly or not. Parliament shall convene of its own accord on the first day of October

\footnotetext{
116 Law No: 1211, 14.01.1970.

117 Presidential Decree No: 3, 10.07.2018, retrieved from http://www.mevzuat.gov.tr/MevzuatMetin/19.5.3.pdf.

118 Fish \& Kroenig, 2009.

119 According to the Presidential Decree, Turkey Radio - Television Corporation General Manager and the member and president of the Board of Directors are appointed by President. See Law with number with 2954 (Turkish), https://kms.kaysis.gov.tr/Home/Goster/25709.
} 
each year and may be in recess for a maximum of three months in a legislative year; during adjournment or recess it may be summoned by the President of the Republic, the Speaker of the Assembly or at the written request of one fifth of the members' (Art. 93).

28.Authors investigated whether deputies were supported on policy expertise with these $28^{\text {th }}$ and $29^{\text {th }}$ elements. Obviously, it is influential to receive support from experts and secretariat to contribute effectively to the policy making of deputies. The headlines are related to each legislator's policy expertise, a personal secretary, and each legislator has at least one nonsecretarial staff member with policy expertise. The answers are yes for the Turkish parliament.

30. Legislators are eligible for re-election without any restriction in Turkey.

31. A seat in the legislature is an attractive enough position that legislators are generally interested in and seek re-election.

32. The re-election of incumbent legislators is common enough that the legislature contains many highly experienced members at any given time. The answer to that is positive. Re-election rates are sufficiently high to produce a significant number of highly experienced members in Turkey. Generally, in this type of model, the systems have popular election, appointment powers, chairing of cabinet meetings, legislative veto powers, foreign policy, and government formation ${ }^{120}$.

Fish \& Kohering's work is primarily based on the legislature. The portrait of the parliament which has become more ineffective in the face of the powerful execution that has emerged with the new system of government is presented above. In the new system, it is necessary to briefly evaluate the state of the legislature as the body most affected by the changes. In delegative democracies, checks and balances are weak, and they are even rationally more ineffective in hyper-presidential regimes. Larkins stated that the president's struggles to re-define "the rules of the game would be difficult without the cooperation or lack of competing institutions". Many scholars underlined that the president's political party is commonly controlled entire or dominate the legislature. Also, they will "either pass supportive legislation or sit idly while the executive alters the political system and makes policy by decree"121.

${ }^{120}$ Siaroff, A. 2003, p. 306.

${ }^{121}$ Larkins noted the authors de Riz, 1996; Keeler and Schain, 1997; Schmidt, 1997 with his book on hyper-presidentialism. Larkins, 1998, p. 67. 


\section{Transformation of the Grand National Assembly of Turkey}

These empirical examples also accept that robust parliaments enable democracy much more than weaker ones ${ }^{122}$. The new system has entered into force with all its components together with the elections in 2018. After this process, the tension between the opposition in the legislative organ and the president representing the executive power has continuously increased when the return to the parliamentary system has started to be discussed.

From the aspect of the legislative organ, it is evident that the separation of powers has become very blurred. The principle that legislative and executive organs cannot terminate the other's duties, which is one of the fundamental characteristics of the presidential system, has been ignored with the president's authority allowing the repeat of elections of the parliament ${ }^{123}$.

With the constitutional amendment majority, TBMM shall be able to decide the repeat of elections. Since the president is authorised to make this decision independently, he has an advantage over the assembly. Here, the imbalance between these two organs is clearly in favour of the president ${ }^{124}$. In addition, the party structure in Turkey decreases the possibility of parties' success against the president by moving together ${ }^{125}$.

Moreover, in the models in which the president is strong and overauthorised, the development of political parties is obstructed due to the system $^{126}$. This system has been adopted upon the promises of efficiency and stability. However, Gönenç stated that the argument that this system is stable and efficient is based on the assumption that the president and assembly majority are in the same political party ${ }^{127}$. However, if the president achieves the majority in the assembly, there will be a one-party regime. Some people may name it "harmony between legislative and executive organs" or "stability", but it is clear that, in this case, the democratisation of the country would depend upon the overlap between democracy's components and this party's preferences. Since the terms in office of the president and Turkish

\footnotetext{
122 Özsoy Boyunsuz, 2016, p. 74.

${ }^{123}$ Esen, 2016, p. 48.

${ }^{124}$ Esen, 2016, p. 49.

125 Gözler, 2016.

126 Cited from Fish p.327-328, Dursun, Hasan, Süper Başkanlık ya da Başkancı Parlamenter Sistem: Weimar Almanya'sı ile Rusya Federasyonu Örnekleri ve Çıkartılacak Dersler, TBB Dergisi, N. 67, 2006, p. 281.

${ }^{127}$ Gönenç, May1s 2018, N. 2018-20.
} 
Parliament (equalization for a period of 5 years and making their elections together) through the amendments, it is promoted for the majority in legislative body and president to be in the same political perspective ${ }^{128}$.

The reverse circumstances would be precarious in countries with underdeveloped democracies. In almost all Latin American countries governed by presidential-like systems, the democratic processes have been interrupted via military coups or populist authoritarian governments ${ }^{129}$. Thus, it is too early to accept the consolidation of democracy with the presidential democracies, although the era of military orphans seems to have closed since the 1990s in Latin America ${ }^{130}$.

In pure presidential systems, the presidential election and constituency election are held separately. For this reason, the transformation into a oneparty regime can be prevented. In elections repeated within two years, the voters do not vote for the president's party in repeated constituency elections and degrade the president to the minority. Thus, it might be prevented for the assembly majority and the president to be from the same party. One of most influential upper houses of the world, the Senate, is renewed every two years in the USA ${ }^{131}$.

Suppose the legislative and executive organs have different political opinions. In that case, the risk of instability will decrease since the legislative and executive powers would not be subjected to the approval of each other due to the strict separation of powers ${ }^{132}$. Esen emphasised that the voters may have different preferences for assembly and president. Thus, the elections made on the same day would not guarantee the majority of assembly for the

128 Gönenç\& Kontac1, 2019, p. 64.

129 Özbudun, 2015. Argentina has not one but two dictatorships - President Alfonsin and President Menem- due to institutional congestion and paralysis. Why did it turn into a dictatorship? Because the absolute majority to support them is not present in Parliament. This resulted in military uprisings and hyperinflation crises in the country. Gülener, Serdar; Başkanlık Sistemlerinde Denge ve Denetleme, Siyaset, Ekonomi ve Toplum Araştırmaları Vakfı, SETA Yayınları 66, I.Baskı, 2016, p. 55 vd.

130 Özbudun, 2015.

131 Erdoğan, Mustafa, Başkanlık Sistemi, Latin Amerika Tecrübesi ve Türkiye, Liberal Perspektif Analiz, N. 3, Aralık 2016, p. 9. Voters dissatisfied with Democrats tends to vote Republican in the next election in cases where the leader of the Democratic Party wins the presidency. Thus it allows Republicans to be a majority in the House of Representatives.

132 Gönenç \& Konatc1, 2019. Cheibub explained that in this kind government, or more precisely its head, serves for a fixed term; thus the executive and the legislature are independent from one another. Cheibub, 2007, p. 16. 
president's party. Moreover, voter preferences may differ if the presidential election winner is concluded in the second round of the election. Finally, the author gave examples of Guatemala ${ }^{133}$, Equator ${ }^{134}$, and Peru ${ }^{135}$, where the elections are made on the same day.

In the new system, since the instruments used by the assembly in supervising the executive power were eliminated, the legislative organ has been inactivated in practice. Esen revealed that the supervising instruments granted to the assembly in the new system were even behind those in substantial presidential systems ${ }^{136}$. It can be clearly seen in the table of comparative authority scores of presidents.

Mainly because the limits of presidential decrees (P.D.) granted to the president to the Constitutional Court decisions on this subject are not clear, the potential of use as an instrument in the arbitrary government of executive power has been frequently emphasised ${ }^{137}$. Moreover, it has also been asserted that they might act as the abolition of the constitutional regime ${ }^{138}$.

By transforming into a single structure, the executive power has been diverted from the body of organs responsible to the parliament ${ }^{139}$. The executive power and authority are gathered in the presidential office. For specific transactions, the president is granted the authority to make regulations first-hand without an obligation to rely upon a law. The previous decree and regulation authorities have been cancelled.

In sustainable democracies, it is the mechanism of control and balance that is essential for the effectiveness of the basic state organs, and this

133 In Guatemala in 1990, Jorge Serrano Elias won the presidential election with $68 \%$ of the vote, while his party only managed $15.5 \%$ in parliamentary elections. Esen, 2016, p. 47.

134 In Ecuador in 1997, Abdala Bukaram was elected president in the second round, while her party won only 15 of the 82 seats in parliament. Esen, 2016, p. 47.

135 In the 1990 Peruvian presidential election Maria Vargas Llosa got 32\% and Alberto Fujimori received $29 \%$ votes in the first tour of election. Fujimori was elected as the President with $62.5 \%$ votes in the second round. However, his party won only 32 of the 180 parliamentary seats. Esen, 2016, p. 47. Javier Hurtado, Gobiernos y Democracia, Instituto Federal Electoral, Mexico, 2012, p. 36.

136 Esen, 2016, p. 51.

137 See Ardıçoğlu, M. Artuk, Cumhurbaşkanlığı Kararnamesi. Ankara Barosu Dergisi, 2017, Vol. 75.3: pp. 19-51. Esen, 2016. Gönenç\& Kontac1, 2019. Şirin, Tolga, İslemeyen Sistemlerin Fonksiyonel Olmayan Yanttı: Cumhurbaşkanlı̆̆ Kararnamesi, Anayasa Hukuku Dergisi, Vol. 7, N. 14, 2018, pp. 289-356.

138 Şirin; p. 343.

139 Ardıçoğlu, 2017, p.33. 
mechanism is the necessity of separation of powers. However, with 2017 constitutional amendments, it is revealed that this mechanism is seen as an obstacle or a defect for political power ${ }^{140}$. Besides, the amendments redefine the relationship between legislative and executive organs. Presidential powers to determine members of different areas of judicial authorities also substantially altered the system alienation from democracy.

Lack of separation of powers effectively and the main character of new system of government bring the criticism of personalization of power. Criticism of presidentialism manifests itself in many areas in terms of 2017's constitutional amendments. For example, Akartürk and Sönmez highlighted the board constitutional powers of president in this sense. The consolidation of powers has led to the centralization of power in the president. Secondly, the party system had led to predominant party. It is yield to party state system which emerges with integration of one party and state even in a multiparty system. Another criticism is the absence of both horizontal and vertical separation of powers. Nepotism, cronyism and neopatrimonialism are other criticisms against the new system of government in Turkey ${ }^{141}$.

Another critical authority is the president's powers over the budget. The existence and continuity of the executive function depend on the budget, and a budget is required, mainly to perform the public functions. The control of parliaments on the budget is traditionally one of the most critical functions of legislative power. As well as creating problems in public finance discipline, the control of assembly on the budget weakened in the amendments creates a problematic situation in terms of the theory of contemporary democracy. With the new budget authority, the president has been entitled to maintain the operations with the previous year's budget "against the TBMM"142.

One of the fundamental problems between legislative and executive organs due to the constitutional amendments is whether the legislative prerogatives can be legally or practically transferred to the executive power or

${ }^{140}$ Akartürk, Ekrem Ali; Küçük, Tevfik Sönmez; Güçlendirilmiş Parlamenter Sistem Teori ve Uygulama, Adalet Yayınevi, 2021, s. 65.

${ }^{141}$ Akartürk \& Sönmez, 2021, p.65-72.

${ }^{142}$ Gönenç \& Kontaci, 2019, p. 70-71. Authors state that whether to continue using the previous year's budget with a revaluation is controversial in case the parliament does not accept the final account law for the previous year. See Turkish Constitution Art. 161 Budget and final account. "The final accounts bill shall be debated and adopted together with the budget bill of the new fiscal year". 
not. Against the principles of generality and inalienability of legislative prerogative, the debate's typical problem is the concentration of executive power in the centre and the operations of executive power. The inalienability of legislative power is discussed mainly in the decree regime. In this context, the legal consequences of authorising/granting and delegating legislative powers are different ${ }^{143}$. Based on the Constitutional Court decision ${ }^{144}$, Teziç stated that the authority is transferred to the transferee in case of such a transfer, and the transferor shall not enjoy that authority for a period. On the other hand, the allocator may retrieve the power in allocating or delegating, and the granter may enjoy the power ${ }^{145}$. Atar pointed out that since both ordinary and extraordinary presidential decrees are issued directly based on the Constitution, there is no such delegation of authority ${ }^{146}$.

Regardless of the form of the system, the democratic character of the system is related to how the check and balance mechanisms have been designed $^{147}$. This system lacks a check and balance function expected in the separation of powers between legislative and executive organs. Since the effective date of this system, the legislative power has never acted as a political power against the executive organ. The substantive authorities granted to the president regarding rulemaking, power of appointment, and budget authorities show that the system has not been designed based on the principle of check and balance. Amendment's objective of strengthening the executive power and providing stability to executive function "against the other organs" overlaps with the practice ${ }^{148}$.

In Turkey, there is a strict harmony between the president and the party holding the majority in the legislative organ because the president is also the

${ }^{143}$ For discussions see. Bakırc1, Fahri, Yasama Sürecinin Hızlandırılmasl - Yasama Yetkisinin Devri vVe Nedenleri Üzerine, Kamu Hukukçuları Platformu Toplantısı Metni, İstanbul, 2930 Nisan 2017.

${ }^{144}$ AYM, 16.9.1993, E. 1992/26, K.1993/28.

145 Teziç, Erdoğan; Anayasa Hukuku, Beta, 19. Bask1, İstanbul, 2015, p.37-38.

146 Yavuz, Atar, Cumhurbaşkanlığ Kararnamelerinin Hukuki Rejimi ve Anayasallık Denetimi, https://www.anayasa.gov.tr/media/6184/yavuz-atar.pdf, 2019, p. 259.

147 Gülener, p. 67.

${ }^{148}$ Sustainable democracy required consensus on the core values of democracy at least of all poles. A sustainable democracy required robust political or constitutional institutions such as legislative and executive authority. Moreover, entails reliable institutions and dynamic participants. There must be stability between government powers with strong opposite interests that obstruct the growth and sustenance of democratic institutions. For sustainable democracy, we must first truly strengthen constitutional rights and freedoms, strengthening governments might not serve this purpose under any circumstances. 
chairman of the government party. The president is the head of both state and executive organ. It can be stated that the president is the epitome of the executive organ. It is debatable if combining all these titles in a single person corroborates an effective and stable government perspective. Because, considering that effective-stable government is the centralisation of all the authorities and the concretion of executive power in a single person without check and balance, the executive function is simplified.

The democratic presidential system is based on the cooperation of the president and parliament, in other words, forming coalitions on various issues. This is one of the features of well-functioning presidential systems. On the other hand, the separation of powers principle, conceived of as a political rather than a legal principle does not require that. It requires that legislative powers, wherever located, should be separated in conception and, as far as possible, institutionally from executive and judicial powers ${ }^{149}$.

The foundation of the new system is built on the centralisation of the executive and its actions. The structure of the exercise has been classified above. In addition, it is necessary to address the administration actions as the most controversial issue of the system and evaluate the current TCC decisions on this issue.

\section{The Turkish Constitutional Court's Exam with Strong Single Executive and Presidential Decrees}

The limits of the subjects under the authority of executive power have not been clarified through the Constitutional Court decisions and do not seem possible. Because the subjects falling within the scope of "executive power" are not clear. This subject will be debated very frequently, and the Court will need to decide in every case.

Almost all references given to the Prime Minister and the Council of Ministers before the amendments have been changed to "president". Although it was considered necessary for the system's proper functioning, it centralised the system on the president. In this framework, various opinions have been put forward on the executive organ and its actions, specifically regarding the hierarchical value and review of the decrees ${ }^{150}$. One of the critical issues is the

\footnotetext{
${ }^{149}$ Waldron p. 465. Manning, John F.; Separation of Powers as Ordinary Interpretation, Harvard Law Review, 1939, 2011, pp. 1944-45.

${ }^{150}$ See Gözler, 2018. Ardıçoğlu, 2017. Eren, 2019. Ulusoy, Ali, Aralık 2016 Anayasa Teklifi Neler Getiriyor, Neler Götürüyor? 2017, Anayasa. gen. tr (online), pp. 1-9.
} 
uncertainty in the first place regarding the decrees. Although some issues are still unclear, the ambiguity regarding the decrees also stemmed from the court decisions regarding the previous decrees.

The constitutional limitation blocking the judicial remedies for the actions solely made by the president was removed. In order to supervise the president's actions in the new system, the actions falling in and out of the scope of the president's administrative function should be identified. Moreover, the president's actions as the head of state or for the sake of the state should be distinguished from the other actions. Administrative proceedings can be filed against administrative actions falling within the scope of the administrative function ${ }^{151}$.

One of the problems with the actions of the executive organ might be the government retrenchment. It is questionable if the president's constitutional authorities, such as issuing laws, ratifying international treaties and requesting the Parliament to prolong the term of the state of emergency, might be considered political and identifying whether such shall be held outside the judicial review. If not controlled, such transactions should be considered in the category of state and executive organ transactions.

Centralisation of the executive organ, especially in the president's person, would make actions and their review more critical. Regarding the review of executive actions, Constitutional Court has the following general statement. In a field to be left for administrative organisation, the fundamental principles, framework, general rule to be followed, and limits shall be regulated via a law by the legislative organ and then it can be delegated to the executive organ.

It should be noted that the amendments granted the president broad authority regarding performing regulatory actions. Besides the issuing bylaws, the authorities granted to the president by the Art. 73/4, and 167/2 of the Constitution have the nature of transferring legislative prerogative ${ }^{152}$. These transactions are out of the Constitutional Court review and are subject to a limited administrative judicial review ${ }^{153}$.

151 İba, Şeref; Söyler, Yasin; Yeni Hükümet Sisteminde Cumhurbaşkanlı̆̆ı Kararnamesi İle Cumhurbaşkanı Kararının Nitelik Farkı ve Hukuki Sonuçları, Anayasa Yargısı, Vol.: 36, No. : 1, 2019, pp. 195-223. p. 216.

152 Esen, 2016.

${ }^{153}$ Esen, 2016. Özbudun, 2015. 
If the Constitutional Court restricts its review area regarding the bylaws, it will increase the "substantial" areas of government strengthened via the amendments. In order to ensure the judicial review in the rule of law, it is compulsory to specify the limits of the government's duties and authorities explicitly ${ }^{154}$. The subjects regulated via presidential decree may also be regulated via law. For this reason, constitutional principles such as proportionality, the essence of the right, requirements of the democratic social order and secularism shall be used in reviewing these bylaws.

The court decisions have primarily clarified the hierarchical value of presidential decrees that have been significantly debated. It has been adopted that they do not have the force of law and are under the law. A democratic ground for a constitution designed by the civil government and in harmony with the country shall be established in Turkey. The constitutions and such radical changes can potentially transform the system, but they entirely reflect the preferences of political power. Even though the constitutional amendments enter into force through a referendum, a process and an environment in which the segment objecting to the amendments in referendum participate shall be created. The only control mechanism is the "vertical accountability" to the public through elections ${ }^{155}$. However, there is no doubt that vertical accountability is not solely enough to make a regime democratic. However, such a regime can be considered a "defective" majoritarian democracy in the best-case scenario or, more probably, as competitive authoritarianism ${ }^{156}$. As the judicial organ and doctrine agreed, the judicial decisions will be discussed over the presidential decrees constituting the central part of the governmental system.

\section{Statutory Decrees (Delegated Decree Power) and Presidential Decrees (Constitutional Decree Power)}

Constitutional Court has related the supervision of previous decrees to their functional character as legislative transactions. Statutory decrees were considered as an organic executive procedure while it was a legislative process in functional terms. Parliament authorised the Council of Ministers to issue

\footnotetext{
${ }^{154}$ AYM, T.11.06.2003, E.2001/346, K.2003/63, R.G.08.11.2003, S.25283. Y1lmaz, Harun, Türk Hukukunda Düzenleme Yetkisinin Tarihsel Gelişimi ve Niteliği, Türkiye Barolar Birliği Dergisi, (110), 2014, pp. 219-240.p. 230.

155 Özbudun; 2015.

156 Özbudun; 2015.
} 
decrees with a law. The Constitutional Court also supervised these authority laws. Since they have not caused the subject, which shall be regulated by the laws, to be taken out of the legislative space and transferred into the executive field, they are not considered the transfer of legislative prerogative $\mathrm{e}^{157}$.

The statutory decrees, which are other types of decrees issued upon an authority law before the Constitution is changed, are considered not as "firsthand" (initial) authority but "derivative" (delegated) authority. The law of authority indicates "the purpose, scope, principles, duration of use and whether more than one decree can be issued within the period of the decree to be issued. ${ }^{158}$ The derivative authority granted to the Council of Ministers was limited to the contest, objective, principle, and time set by the law.

The court emphasised a general statement that in a field to be left for administrative organisation, the fundamental principles, framework, general rule to be followed, and limits shall be regulated via a law by the legislative organ and then delegated to the executive organ ${ }^{159}$. The Court has previously emphasised that, for the government to make a regulation, the law shall set the fundamental principles of the field left for the government and, in other words, the framework shall be drawn ${ }^{160}$. According to the TC, although the legislative organ has the primitive and fundamental regulatory power, it is not authorised to assign this power or make a law resulting in a transfer of this power. According to the generally accepted opinion, granting the discretionary government power with uncertain limits is against the principle of inalienability of the legislative prerogative ${ }^{161}$.

Since the presidential decrees are issued directly based on the Constitution, there is no delegation of authority in this subject ${ }^{162}$. As the formation is mainly concentrated in the president's control, it causes the issue of actions and their control to be more vital. As it is known, the rule of law determines an administration that prevents the arbitrariness of the administration, and its rulers are obliged by law. Such requires the effective control of administrative processes and actions and the executive to be an

\footnotetext{
157 AYM, 5.2.1992, E.1990/22, K.1992/6.

158 AYM, 27.10.2011, E.2011/60, K. 2011/147.

159 AYM, 29.11.2006, E.2004/102, K.2005/96. AYM, 23.02.2006, E.2005/42, K.2006/27.

${ }^{160}$ AYM, 01.06.2005, E.2004/60, K.2005/33.

${ }^{161}$ AYM, 23.10.1969, E.1967/41, K.1969/57. Doğan, Bayram, Cumhurbaşkanlı̆̆ı Hükümet Sisteminde Cumhurbaşkanliğ̀ Kararnamelerinin Yasama Yetkisinin Devredilmezliği Bağlamında Değerlendirilmesi, SÜHFD, C. XXVIII, P. 3, 2020, pp. 965-1003.

162 Atar; p. 257-258.
} 
accountable and transparent body. In this sense, the situation of the competent judge in the supervision of the enforcement procedures has been evaluated above.

It has also been suggested that the new system does not preclude democratisation but instead has the potential for change in political life that will strengthen democratisation. However, these studies do not include concepts such as the status of the impartial president and the president who is the leader of a political party ${ }^{163}$. The presidential decrees have been widely regulated, and it has been noted that Presidential decrees are one of the main elements of this Turkish-type presidential system ${ }^{164}$. In some countries that adopt the presidential system and its derivatives, these appointing powers are shared between legislative and executive bodies ${ }^{165}$. These presidential decrees are similar to the presidential decrees applied in Russia ${ }^{166}$ and Azerbaijan ${ }^{167}$.

According to the Constitutional Court, the most remarkable character of the presidential decrees is that the President is granted the authority to regulate specific subjects first hand (substantive)" 168 . Court has accepted that the President has been granted the authority to make first-hand regulations on specific subjects ${ }^{169}$.

The decree based on the "authority law" left to the discretion of the legislative organ has been replaced by the direct "Constitution-based" decree. However, it is now necessary to assess the decisions of the Constitutional Court in order to identify the current situation ${ }^{170}$.

163 Alkan, Haluk, Cumhurbaşkanlĭ̆ Sisteminin Kurumsal Özellikleri ve Demokratikleşme Sürecine Olası Etkileri, Türkiye İletişim Araştırmaları Dergisi, 30-Medya ve Demokrasi,2018, pp. 139-153.

164 Ozan Ergül, Yeni Rejimin Kodları: Cumhurbaşkanlığı Kararnameleri, Güncel Hukuk, 2018, N.173, pp.30-34. Tolga Şirin, İşlemeyen Sistemlerin Fonksiyonel Olmayan Yanıtı: Cumhurbaşkanlığı Kararnamesi, Anayasa Hukuku Dergisi, Vol. 7, N. 14, pp.289-356. İba \& Söyler, 2019, p.195-223

165 Gönenç \& Kontaci; p. 70.

166 Russian Constitution Art. 90.

167 Azerbaijan Constitutiona Art. 148.

168 AYM, 11/06/2020, E.2018/155, K.2020/27, § 4. Doğan, 2020, p. 965-1003.

169 AYM 22.01.2020, E.2018/125, K.2020/4. AYM 23.01.2020, E.2019/31, K.2020/5. AYM 23.01.2020, E.2019/78, K. 2020/6. Sevgili Gençay, Fatma Didem; Cumhurbaşkanliğ Kararnamelerinin Yargisal Denetimi: Illk Kararlar - İlk İzlenimler, TBB Dergisi, 2020, N. 151, p. 5.

170 Yıldırım, T. Cumhurbaşkanlığı Kararnameleri, Marmara Üniversitesi Hukuk Fakültesi Hukuk Araştırmaları Dergisi, Vol. 23, No. 2. 2017, pp.13-28, p.23. Eren, Abdurrahman, 
The way decrees are introduced with amendments differs from those envisaged in pure classical presidential regimes. They are a form of regulation found in democratic democracies. The area for this arrangement should be interpreted narrowly.

A previous rule of the Constitutional Court stating that the subjects, which have been projected to be regulated by the laws, might be regulated by the bylaws on the condition of remaining within the constitutional limits has become debated from the aspect of the decrees in the new system. Nevertheless, the opinions that this rule cannot be applied to the Presidential Decrees showed the accuracy of the Constitutional Court in its decisions ${ }^{171}$.

In the Constitution, it is regulated that annulment action may be filed against the decrees in case of unconstitutionality. However, it is unclear if an action can be filed with the claim of unlawfulness. The previous decrees have been based on an authority law ${ }^{172}$. There was no provision regulating the compliance review regarding the authority law for these decrees. The Constitutional Court ruled that presidential decrees should also comply with "authority law" through an interpretation. Although it has been ruled that the Constitutional Court shall conduct a "constitutionality" review, various problems may arise since there has been no explicit provision in the 1982 Constitution regarding conducting the "lawfulness" review ${ }^{173}$. Since the Constitution rules that the authority of issuing presidential decrees shall be enjoyed under "constitution and laws" and the principle that no decree should be issued on a subject regulated by law has been adopted, the legality should also be sought ${ }^{174}$.

\footnotetext{
Anayasa Mahkemesinin Kanun Hükmünde Kararnamelere İlişkin İçtihadı Doğrultusunda Cumhurbaşkanlığı Kararnamelerinin Değerlendirilmesi, Anayasa Yargısı, Vol. 36, No. 1, 2019, pp. 1-72, p. 10.

171 Ardıçoğlu, 2017, p. 50.

172 Teziç, p. $37 \mathrm{ff}$.

173 Yeniay, Lokman\& Yeniay, Gülden, Türk Hukukunda Yürütme Organinin Düzenleme Yetkisi Ve Cumhurbaşkanliği Kararnamesi, Anayasa Yargısı, Vol.: 36, No. : 1, (2019), pp. 105-138.

174 Eren, p. 49, 57.
} 


\section{General Evaluation on the TCC Decisions Regarding the Presidential Decrees}

Constitutional Court clarified the exclusive field of law as "the subjects specified to be regulated by law in the Constitution"175 The Court ruled that the laws have reserved areas, but the Presidential Decrees have been restricted ${ }^{176}$. Sevgili Gençay concluded that "there is no space allocated to presidential decree and banned for the law; the laws might be made even on the subjects specified to be regulated by presidential decree in the Constitution ${ }^{177}$.

It has been suggested that the four issues stated to be regulated with the CBK in the Constitution constitute the exclusive regulatory area of the executive body. Others have argued that it should be accepted that the legislature cannot enact laws on these issues ${ }^{178}$. The Court has specified the procedure that it will follow in the review of presidential decrees as follows: "First, the decrees (in Art. 104/17) should be reviewed in terms of the compliance with authority rules in terms of the subject". In case of no incompliance from this aspect, the review for constitutionality shall be initiated from the substantial aspect. Thus, it will not be necessary to check whether the contents of the decree issued in an unauthorized area are under the Constitution.

Issuing a decree on an unauthorized field would violate the principle of inalienability of legislative prerogative. The presidential decrees passing beyond the scope of authority from the contextual aspect would be the seizure of authority (dysfunction ${ }^{179}$

The Court ruled that "Presidential decrees shall be issued following the authorization rules from the aspect of context. Otherwise, even if the context is not unconstitutional, these regulations shall not be considered to comply with the Constitution. Thus, in the judicial review of presidential decrees, the compliance with Art. 104/17 of Constitution should be examined from the contextual aspect first". Accordingly, in case of no violation, the constitutionality of presidential decrees shall be examined ${ }^{180}$.

175 AYM, 22.01.2020, E.2018/125, K.2020/4.

176 This determination is reflected by Ardıçoğlu previously stated before.

177 Sevgili Gençay, p. 11

178 These exclusive areas are mentioned above.

179 Sevgili Gençay, p. 11

180 AYM, 11/06/2020, E.2018/155, K.2020/27, § 13. 
In its decisions reviewing the presidential decrees, TCC passed the annulment decision without discussing the context since the president has made regulation on a subject ${ }^{181}$ for which the president had no authorization (general authorization rules outlined in Art. 104/17).

In this context, the Court also carried out the same review procedure under the supervision of previous decrees. The first stage of the review carried out by the court was seen as a kind of barrage. Issuing a decree on an unauthorized subject means that the legal transaction is considered null and void. In constitutional jurisdiction, the annulment may be considered in cases of the usurpation of authorization and duty or very severe formal defect. In this case, the Court may give an "annulment" (nullity) decision ${ }^{182}$.

The source of power in presidential decrees is the Constitution, but, from the aspect of the subject, the constitution's provisions are not as straightforward as in the subjects regarding the authorization of executive power. Therefore, independently from the detection of lack of authorization, the Court should also share its determination on the context in presidential decrees. Court decisions are binding, and sharing the contextual determinations about the decrees would shed light on the contexts of the subsequent decrees.

For the decrees, for which the Court found no violation of authority, the Court investigates the compliance of decrees with the principles of the state of law. In this context, the Court has emphasised the specificity, objectivity, and clearness of the $\mathrm{PD}^{183}$.

Waldron emphasize that "separation of powers, is indifferent to delegation provided that the institution to which law-making is delegated remains distinctively legislative in character and, as I said, it is distinguished clearly in conception and, as far as possible, institutionally, from judicial and enforcement functions wherever they, in turn, are located" 184 . It points out that

181 AYM, 23/1/2020, E: 2019/31, K: 2020/5. As a matter of fact, the subject of the review is in the second decision, rule regarding non-budget cash advance annulled without needing to be examined in terms of content since it was found to be contrary to the Article 104/17/4 of the Constitution.

182 Aliefendioğlu, Yılmaz; Anayasa Mahkemesi Kararları Işı̆̆ında "Yokluk" ya da "Yok Işlem", TBB Dergisi, N. 81, 2009, p. 9.

183 AYM, 23/1/2020, E.2019/31, K. 2020/5, §. 37-38. Also AYM, 22/1/2020, E.2018/125, K. 2020/4 prg. §. 23, 24, 25 and. AYM, 23/1/2020, E.2019/78, K. 2020/6, §. 23, 24, 25, 26.

184 Waldron, p. 459. 
the fact that the legislature should be "clearly in conception and, as far as possible, institutionally, from judicial and enforcement functions wherever they, in turn, are located" is the basis of the separation of powers. Indeed, the Court will determine the "executive subject" every time eliminates this apparent distinctiveness. The separation of powers is not a legal principle on paper, and it is more important to establish it as a political principle in practice. Rather than the term "executive", a narrower concept should be used for the authority of presidential decrees ${ }^{185}$.

It should be remembered that the TCC has entitled the separation of powers a fundamental constitutional choice. As stated in the TCC's decisions, superiority is in the Constitution and laws. The Court cites a reference to the separation of powers and the Constitution as a requirement of the rule of law $^{186}$. Due to the readable spirit in the text of the constitution, the judiciary should have a role in the critical sense in order for this sequence to be de facto functional $^{187}$.

The limits of the subjects under the authority of executive power have not been clarified through the Constitutional Court decisions and do not seem possible. Because the subjects falling within the scope of "executive power" are not obvious ${ }^{188}$.

Since all the subjects within the scope of the executive authority of the Court cannot be specified one by one, Constitutional Court makes a thorough analysis on any rule submitted to it. For example, the Court ruled that the presidential decree created an amendment in the law, but the law shall be amended by law ${ }^{189}$. Subsequently, the presidential decree was issued for a

185 A narrower concept should be used in the Constitution instead of the expression "on the matters regarding executive power". In this regard as stated by the Gözler it should be considered as an executive organ. Gözler, Türk Anayasa Hukuku, p. 924.

186 The preface text of the Constitution makes it clear that separation of powers does "not imply an order of precedence among the organs of the State" This principle refers solely to the exercising of certain state powers and discharging duties, and is limited to a civilized cooperation and division of functions; and the fact that only the Constitution and the laws have the supremacy". AYM, 4.5.2017,E.2015/41, K. 2017/98, §. 158.

187 Readable spirit of the Constitution is kind of ironic statement. In Turkey, the text and the spirit of the Constitution have been discussed to a very great degree or extent. At this point, the practice is not compatible with the text of the Constitution or the constitutional "spirit" in the minds of individual.

188 Ardıçoğlu, 2017, p. 25.

189 AYM, 11/06/2020,E.2018/155, K.2020/27. 
subject that the parliament must regulate, the Court has annulled that decree. In another decision, the Court has ruled that approving the international agreements is within the executive scope of presidential decrees, and the Court has then declared the constitutionality of decree. However, the limitations regarding the issues under "executive authority" do not seem to be clarified by TCC. Since it is unclear what the issues related to "executive authority". Gözler points out that this issue will be highly controversial, and the TCC will determine it in each case ${ }^{190}$.

In one of its decisions on a presidential decree, Court investigated the executive power regarding the approval of international agreements. According to the Court, approving the agreements is under the authority of the president. However, approval of certain agreements depends on the prior approval of parliament via a law. In that decision, the Court investigated if approving the agreements was within the executive authority. As a result, the Court declared that these agreements shall be published. As long as not being of particular concern to real persons and legal entities ${ }^{191}$, the agreements may also be abolished before putting them into effect ${ }^{192}$.

For the reason that, in case of passing beyond the executive prerogative and entering under the legislative prerogative in terms of the effects on fundamental rights and freedoms, the presidential decree would be unconstitutional. From this aspect, ignoring the substantial effects, every regulation should be subject to review by constitutional jurisdiction ${ }^{193}$.

This point became more critical in the period when the Istanbul Convention ${ }^{194}$ was avoided by a presidential decision that was one of the president's actions ${ }^{195}$. It was specified in the presidential decree that the

190 Gözler, Kemal, Türk Anayasa Hukuku, $3^{\text {rd }}$ Ed. Ekin Yayınevi, Bursa, Ocak 2019, p. 924.

191 For criticisms on this topic, see. Gözler, Türk Anayasa Hukuku, p.714.

192 AYM, 25/06/2020 E.2018/128, K.2020/32.

193 Ardıçoğlu, 2017, p. 38-41.

194 Art. 80 of the Convention stated that "Article 80 - Denunciation 1 Any Party may, at any time, denounce this Convention by means of a notification addressed to the Secretary General of the Council of Europe. 2 Such denunciation shall become effective on the first day of the month following the expiration of a period of three months after the date of receipt of the notification by the Secretary General". Council of Europe Convention on preventing and combating violence against women and domestic violence, (Avrupa Konseyi Sözleşmeler Dizisi - No. 210 Kadına Yönelik Şiddet ve Aile İçi Şiddetin Önlenmesi ve Bunlarla Mücadeleye Dair Avrupa Konseyi Sözleşmesi) İstanbul, 11.V.2011, https://rm.coe.int/1680462545, https://rm.coe.int/168046031c.

195 Date: 20/03/2021, Number 31429, Official Gazette The Decision Regarding Termination of the Istanbul Convention Number 3718. "İstanbul Sözleşmesinin feshi hakkında karar". 
Istanbul Convention had been avoided. From the aspect of presidential decrees, the statement "on the matters regarding executive power" (Art. 104) "subjects under the executive prerogative" in the Constitution paved the way for uncertain and arbitrary decisions via the presidential decrees. Because the decree on the annulment of the contract was attributed to the authority of the President set by Presidential Decree No.9, this authority has been directly recognized by the decree issued by the president.

Art. 3 of the Presidential Decree No. 9 stated that "Ratification of international treaties suspension of the implementation of their judgments and their termination shall be subject to the decision of the President of the Republic" ${ }^{196}$. An annulment action was filed against the Decision for the unconstitutionality, but the unconstitutionality could not be detected for the Decree Nr. 9. The Court has investigated the decree from the aspect of other provisions. In our opinion, the relevant Art. 3 is unconstitutional. However, the period of litigation has passed in front of the TCC.

According to the principle of formal parallelism or the principle of the congruent form (yetki koşutluğu) ${ }^{197}$, the agreement shall be appropriately avoided by the parties, who are entitled to transpose it to domestic law, following the order of passing it to domestic law ${ }^{198}$. This principle is that "an administrative organ or office that is authorized to establish a transaction means that, unless there is a complete opposite event or if there is no legal regulation on this subject, then the officers shall remain in their position" 199 . On the contrary, within the scope of this principle called parallelism in transaction or authority or method, the president is not authorized to transpose the human rights agreement to the domestic law on his/her own. On this subject, the parliament shall approve the agreement via a law. However, a president authorized by law can approve an agreement and issue a presidential

196 Article 3. Presidential Decree No. 9, Presidential Decree on the Procedures and Principles for the Ratification of International Treaties (Milletlerarası Andlaşmaların Onaylanmasına İlişkin Usul ve Esaslar Hakkında Cumhurbaşkanlı̆̆ Kararnamesi), Date: 15/7/2018, No. 30479. https://www.mevzuat.gov.tr/MevzuatMetin/19.5.9.pdf

197 Sar, Enes, Cakiroglu, Berivan, Ozdogan, Emre, The Principle of Formal Parallelism Or the Principle of Congruent Form in Turkish Administrative Law, 20 GSI Articletter 115 (2019), pp. 115 to 128.

198 TC set for the statement as "international agreements duly put into effect" (Art. 90).

199 According to the rule of authority which is developed by case law, an administrative authority which has carried out an administrative act is also entitled to change abolish and revoke that administrative act unless a judgment is found to the contrary. Günday, Metin; İdare Hukuku, 8. Bask1, Ankara, 2003, p.124. 
decree on this subject. Thus, if it cannot be approved without authorization by the parliament, then, according to the parallelism in authority or method, the dissolution of the agreement is subject to the same rules ${ }^{200}$. For this reason, as specified above, this Decree is considered null and void since it has been issued on an "unauthorized field". Thus, the agreement shall be considered in effect in domestic law.

Also, the action projecting the termination of the international agreement is a presidential decision. Its annulment shall be requested via a suit to be filed in the Council of State ${ }^{201}$. The transaction's contradiction to Art. 13 of the Constitution should be asserted because the law shall restrict fundamental rights and freedoms. As known, the states have positive and negative obligations regarding rights and freedoms. The state also has negative obligations arising from the protection it did not provide, but it should have provided or the action it did not take. However, it should have taken, as well as the negative obligations arising from the negligence of the state. Unilaterally annulling an agreement ensuring the international guarantee of any right and freedom would obviously burden the rights and freedoms. Moreover, it indicates that the state does not fulfil its negative obligation. The relevant transaction is a unilateral transaction. Since it is not explicit and predictable, it does not comply with the perspective of qualified law, which is sought to restrict the rights and freedoms.

In its decision on the executive international agreements, the Court has not investigated the legislative organ's authority of approving the agreements before publishing them ${ }^{202}$. As in the termination of the agreement, this subject will also be obviously debated more. Considering these determinations of the Court, it can be seen that the jurisdiction shall make numerous determinations between the legislative and executive organs regarding the "executive" subjects. This indicates that the Court will be criticized for the review of expediency in the future.

200 Council of State Decision (Danıştay) 8. Daire, 26.11.2013, E. 2013/5211, K. 2013/8692. The power given to an authority in public law is exercised by that authority unless there is a contrary rule. It is undeniable that it will have to be empowered by legislation for the transfer of authority from one office to another. Council of State Decision 5. Daire, 15.04.2003, E. 2000/1711, K. 2003/1421.See Art. 155 of the TC regarding to find out authorities and situation of the Council of State in Higher Court.

201 Art. 24 of Council of State Law, Law No. 2575, https://www.mevzuat.gov.tr/MevzuatMetin/1.5.2575.pdf.

202 About discussion on the matter see Gözler, Türk Anayasa Hukuku, p. 713 -714. 
Another point about the decrees is that no presidential decree shall be issued on the subjects projected in the Constitution to be exclusively regulated by the law, and "No presidential decree shall be issued on the subjects that are explicitly regulated by the law". In its decisions to date, the Court has partially clarified these subjects. However, in the established case law of the Constitutional Court, it is accepted that the issues that the constitution requires to be regulated by law should be seen in this context ${ }^{203}$.

Since the Constitution includes no specific provision about which the law shall exclusively regulate subjects, this subject is very debatable. The Court has clarified that no presidential decree shall be issued on the subjects, which have been projected to be regulated by the law in the Constitution. Moreover, the Court also emphasized that the fundamental rights and the subjects, which the Constitution projected to be regulated exclusively by law, shall not be regulated via presidential decrees ${ }^{204}$. Regarding the decrees, there also is another debate that decrees shall not be issued on personal rights and political rights, but the "economic, social rights" might be regulated via these decrees. Because, in the articles of the Constitution regarding the economic and social rights and freedoms, provisions are imposing the order of regulation by law. For instance, "The scope of the right to education shall be defined and regulated by law" in the "Right and duty of education" (Art. 42). The measures related to the positive duties assigned to the state regarding putting these rights into practice might be regulated using the decrees. However, the individuals shall not be alienated from enjoying these rights, and no provision on these rights shall be set. Because, since it is about the imperative provisions of the Constitution on the limitation of fundamental rights and freedoms (Art. 13), a limitation addressing these rights and freedoms shall be made via law by the legislative organ ${ }^{205}$.

203 AYM, E.2016/150, K.2017/179, 28/12/2017, § 57; E.2016/180, K.2018/4, 18/1/2018, § 17; E.2017/51, K.2017/163, 29/11/2017，§ 13; E.2016/139, K.2016/188，14/12/2016, § 9; E.2013/47, K.2013/72, 6/6/2013

204 In one of the last decisions of the TCC on the presidential decrees clarified that "the authority to establish foreign organizations within the scope of the organization of the ministries is given to the President decree. Also it is not possible to leave this primary authority granted to the presidential decrees to another administrative action. However, it is not necessary for the executive body to regulate all kinds of details regarding the subject that the PD is authorized to issue with the PD and to fulfill the requirements of these regulations personally, after determining the basic rules and drawing the general framework with the PD. It is possible to leave the necessary savings to the relevant administration within the scope of the regulations (Art. 106). AYM, 12/6/2020, E.2019/105, K. 2020/30, prg. 36.

205 Ardıçoğlu, p. 41. 
It has also been stated that the social and economic rights, which have not been projected to be regulated by law in the Constitution, such as Art. 56, "Health services and protection of the environment" and "Right to Housing" (Art. 57), which have not been projected by Constitution to be regulated by the law, might be regulated via presidential decree ${ }^{206}$. The Constitutional Court seems to adopt this approach in its decisions to date.

Moreover, the subjects projected to be regulated via presidential decree may also be regulated via law. In the Constitution, the regulations specified to be regulated via presidential decrees and granting the president authorization shall not create an exclusive space on their own. Thus, it is beyond question that the legislature's power to regulate these matters has been terminated.

The Court has also clarified the provision, which is another debated point from the views of decrees, that no presidential decree shall be issued on the fields explicitly regulated by the law ${ }^{207}$. The Constitution stipulates explicitly that an issue should be regulated by law, which means it wants this area to be regulated exclusively by law ${ }^{208}$. Therefore, it is considered affirmative that the court determines or confirms the reserved areas of the legislature with its decisions ${ }^{209}$. Since the legislative power is general, it should be noted that each issue is in its exclusive area.

Accordingly, it should be determined if the relevant law has a provision on the subject regulated by the presidential decree. Then, it should be determined if the regulation is explicit or not. From this aspect, regarding if the presidential decree has been issued on a subject explicitly regulated by law, the principle "If the presidential decree has not been issued, would the provision of law taken into comparison be applied to the subject regulated by the presidential decree" is accepted as standard ${ }^{210}$.

If the constitution-maker projects that the law shall regulate a subject, then it means that field shall be exclusively regulated by law. Moreover, according to the Court, even if a law granted the President authorization to regulate a subject via presidential decree, the presidential decree shall not be considered constitutional. If the presidential decree is issued on a subject

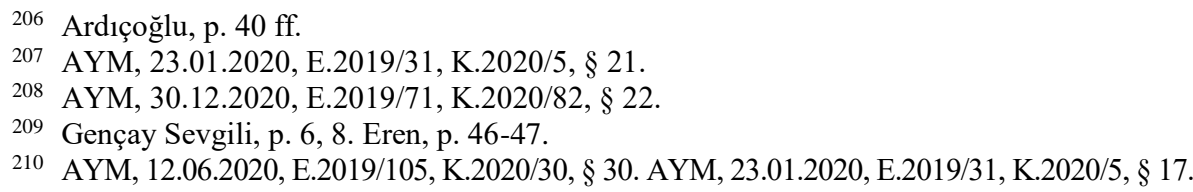


explicitly regulated by the law, then both the law empowering the president and the presidential decree would be unconstitutional ${ }^{211}$.

The most crucial aspect of the president's authority regarding issuing presidential decrees is related to the state of emergency. The president may declare a state of emergency on his/her own and, in this period, limit the rights and freedoms via the emergency bylaws. The rights and freedoms may be suspended in emergency periods to overcome the crises, but these transactions shall not be excluded from the judicial review. The emergency presidential decrees to be issued by the president via amendments are out of the judicial review. The most prominent characteristic of Latin American presidential systems is granting the presidents the authority to issue bylaws in emergency government procedures. However, they are not excluded from the judicial review in any country ${ }^{212}$.

It is seen that the legislative and judicial control that will allow it to be used within constitutional and legal limits is very underprivileged ${ }^{213}$. This system of government is clearly uncertain in practice ${ }^{214}$. Turkish presidentialism is especially problematic due to its flawed design regardless of who occupies the president's seat. Particularly concerning are the weakness of the parliament and the judiciary vis-à-vis the president, who enjoys vast appointment powers and limited horizontal accountability. ${ }^{215}$

It does not matter whether the authority in question is legitimate, for example, on account of its democratic credentials. It does not matter that it has been, in some overall sense, authorized by the people. Even if the exercise of power has been legitimated democratically-in the sense that someone has been chosen as a political leader in free and fair elections and now he wants to put the policies that he ran on into force-still, what he proposes and regards himself as authorized to do must be broken down into these parts. It must be housed in and channelled through these procedural and institutional forms, successively one after the other. That is what the rule of law requires, which is maintained too by separation of powers. The legislature, the judiciary, and

${ }^{211}$ AYM, 23.01.2020, E.2019/31, K.2020/5, § 21.

212 Esen, 2016, p. 51.

213 Esen, 2016, p. 56.

214 European Commission for Democracy through Law (Venice Commission), Opinion No. 875/2017, CDL-AD (2017)005, § 108, 17.

215 Berk Esen \& Sebnem Gumuscu, The Perils of "Turkish Presidentialism", Review of Middle East Studies, Middle East Studies Association of North America (MESA),Vol. 52, No. 1, April 2018, pp. 43-53, p. 44. 
the executive-each must have their separate say before power impacts the individual.

\section{Measuring Presidential Powers within the Framework of New Form of Government in Turkey}

As many have stated before, to understand how form of government really work, it is necessary to examine all the influencing variables as normative/institutional and behavioural dynamics. Özsoy Boyunsuz pointed out that these dynamics help us diagnose the functioning of system of governments and enable us to differentiate the differentiated sub-types ${ }^{216}$. For example, many studies have conducted measurements of the powers of presidents and estimated the consequence of variation in presidential power ${ }^{217}$. As Doyle and Elgie pointed out, measuring the constitutional powers of presidents is somehow challenging since constitutions can be defective measures of actual political power. Nevertheless, the behavioural power of presidents is also problematic because there is the peril of taking the influence of some factors, for instance, party competition, rather than the power of the presidency itself ${ }^{218}$.

Measuring the powers of the presidents is not a distant topic in Turkish legal literature. Separation of the system from other forms of government by using these measurements was made for the first time by Özsoy Boyunsuz in 2007. Author scoring the powers of the presidents of state was used to distinguish between semi-presidential and parliamentary systems. Since it was in question that the president of the state in Turkey would be elected by the people, and this constitutional amendment was made in that year. The author assumed that if the powers of the president of state are not very high, the system cannot be considered semi-presidential even if the people elect the head of state. The same measurements and criteria were used in the Author's evaluations of the system in Turkey on that date ${ }^{219}$. Gönenç and Kontac1 discussed the rationale behind the 2017 amendments. They considered the

\footnotetext{
216 Özsoy Boyunsuz, 2014 p. 23.

217 A widespread, comprehensive and up-to-date study on this subject was conducted by Doyle and Elgie. Doyle, David, and Robert Elgie. "Maximizing the reliability of cross-national measures of presidential power." British Journal of Political Science N. 46.4, 2016, pp. 731-741..International Political Science Association biennial conference, 20-24 Jul 2014, Canada, p. 3.

218 Doyle and Elgie, 2014, p. 7.

219 Özsoy Boyunsuz, 2014 p. 96.
} 
constitutional structure with particular reference to new relevant classification forms of government with the conceptual framework and several deficiencies of the current structure regarding legislative-executive relationships. They drew attention to the presidential powers struggling to identify a new form of government ${ }^{220}$.

In the new system, the president is subject to minimal supervision of legislative and judicial organs, and the principle of the separation of powers has been weakened in both practice and on paper. Since it is challenging to classify these "hybrid" systems, which arose since the 1990s, into any category within classical types of forms of government, new classifications have emerged. The most remarkable one among them is the quintet classification developed by Shugart ${ }^{221}$. These classifications are taken as the basis of the study. In this study, the authority granted to the president in Turkey's newly adopted constitutions is examined using a list of powers established by Shugart \& Carey (1992), as a means of classifying different systems of government or regimes. Classification by analysing the powers of presidents in different categories was performed by Metcalf (June 2000), Fortin $^{222}$ (2012,), (Özsoy Boyunsuz, 2014) (Gönenç \& Kontacı, 2019) and many others.

Shugart \& Carey's categorising of the presidential powers offered a distinct group of legislative and non-legislative presidential powers. Legislative powers refer to presidential power in the legislative process. On the other hand, non-legislative powers refer to constitutional limits placed on the separate origin and survival of the president and the assembly. These powers may be measured based on a scale from 0 to 4 in their leading study of authors ${ }^{223}$. Meanwhile, Metcalf has offered some improvements to these measurements ${ }^{224}$.

Many different methods are used in the analysis of the form of systems. At this point, the measuring of the powers of the president provides significant

220 Gönenç \& Kontac1, 2019, p. 54.

221 Gönenç, \& Kontac1, 2019, p. 60-61. The following two systems have been added to the classical classifications. These are "presidential parliamentarian system" and "super presidential system".

222 Fortin, J. Measuring presidential powers: Some pitfalls of aggregate measurement, International Political Science Review, V.34 (1), 2012, pp. 91-112.

223 Shugart \& Carey, 1992, p. 150.

224 Metcalf, June 2000, pp. 669-670. 
results. In addition to many others, Shugart \& Carey (1992), Frye $(1997)^{225}$ or Metcalf (1998) ${ }^{226}$ (June 2000) are fascinated by these measurements. First, Shugart \& Carey examined the vital power of the presidents by holding to their legislative powers and non-legislative powers categories. According to the severity of these powers, they make ratings by scoring between $0-4$. Among the legislative powers, the veto power, the power of decree, the policy areas dedicated to the president, the budgetary power, the power of referendum, and the power of application to the Constitutional Court, which may affect the legislative process. Also, non-legislative powers examined the formation of the cabinet, the reduction of the government, the reduction of the government by the mechanism of the vote of confidence, and the powers of termination of the parliament. In this study, the Turkish presidential system will be examined based on the results of Shugart \& Carey, who proposed revisions to their measurements of Metcalf studies ${ }^{227}$. The types of powers discussed below will provide a general framework for the president's powers. Such types will be briefly addressed in terms of comparison of scoring of the president's powers in other examples of system of government.

\section{Legislative Powers of the President According to the New Constitutional Amendments in Turkey}

The newly adopted TC granted the president substantial legislative powers. Metcalf, Shugart \& Carey defined legislative powers as the "presidential power in the legislative process, which may be provided in the

225 The Frye recommended List of Presidential Powers as follows; 1. Dissolves parliament, 2. Calls referendums, 3. Calls elections, 4. Appoints prime minister, 5. Appoints ministers, 6. Appoints constitutional court, 7. Appoints supreme courts, 8. Appoints judges, 9. Appoints prosecutor general, 10. Appoints central bank chief, 11. Appoints Security Council, 12. Appoints senior officers, 13. Appoints senior commanders, 14. Commander-in-chief of armed forces, 15. Chairs national Security Council, 16. Remands law for reconsideration, 17. Sends law to the constitutional court, 18. Proposes legislation, 19. Issues decrees in nonemergencies, 20. Proposes amendments to the constitution, 21. Calls special sessions of parliament, 22. Special powers if parliament is unable to meet, 23. Assumes emergency powers at other times, 24. Participates in parliamentary sessions, 25. May address or send messages to parliament, 26. May convene cabinet sessions, 27. Participates in cabinet sessions Frye, T. A Politics of Institutional Choice Post-Communist Presidencies, Comparative Political Studies, Vol. 30(5), pp. 523-552.

226 Metcalf, Lee Kendall, The evolution of presidential power in Estonia 1920-1992, Journal of Baltic Studies, Vol. 29(4), 1998, pp. 333-352.

227 Please see definition of presidential system in presidentialism and hyper-presidentialism. Shugart \& Carey, 1992, p. 19. 
Constitution or delegated to the president" by the parliament ${ }^{228}$. Shugart \& Carey separated the president's legislative powers as constitutional (entrenched) presidential power and legislative power delegated to the president by Congress in two dimensions ${ }^{229}$. The authors shown in the table below have determined legislative powers as package veto/override, partial veto/override, and decree, exclusive introduction of legislation (reserved policy areas), budgetary powers, and proposal of referenda ${ }^{230}$. Since the constitutional amendments were submitted as a draft, the new regime of the presidential powers is expressed as a wide range of legislative and nonlegislative powers are bestowed upon the Turkish president ${ }^{231}$.

\subsection{Proposal of Referenda}

Before recently amended for the nineteenth, Turkey's constitution was adopted in 1982. It designates for a unicameral legislature; before the latest amendments, there was a prime minister as the head of government, and head of state, elected by the parliament, as the president. The president has the power to submit constitutional amendments proposed by the parliament to a popular referendum. Preceding 1982, the parliament could act alone to change the constitution.

According to Shugart \& Carey, they grant the president the power to propose referenda, usually on matters that the assembly has previously rejected. The score will be 4 out of 4 in case of the power is not restricted ${ }^{232}$. The authors portrayed the circumstances in which the president alone could not exercise the referendum power as restricted and scored 2 points. As Metcalf pointed out, the meaning of the term restricted needs to be explained. The author described and proposed as "it appears to refer to a shared power where either the president acting alone or the assembly acting alone can propose referenda. It is also necessary to add a score of 1 for the situation in which the president acting with the cabinet may propose referenda"233.

Metcalf, Shugart and Carey proposed measuring scale in restricted categories covering cases where the president can exercise this power alone,

228 Metcalf, 1998, pp. 333. Shugart \& Carey, 1992, p. 19, 131.

229 Shugart \& Carey, 1992, p. 131.

230 Shugart \& Carey, 1992, p. 150.

231 Özsoy Boyunsuz, 2016, p. 78.

232 See the scores of these powers in Appendix I. Shugart \& Carey, 1992, p. 152.

233 Metcalf proposed to revise on the Proposal of Referenda Powers of the presidents. Appendix II. Metcalf, June 2000, p. 671. 
but only for "certain types of laws". In this case, the president is the only one having the power to hold a referendum on laws that constitutional amendments. To use this power alone should be evaluated at least a restricted category in in any kind of legislation classification. Particularly, only the president has the power to submit to referendum of a law which a law can amends the Constitution. According to the Constitution the referendum must be held by necessity in some cases. However it should be noted that the parliament does not have the power of referendum. Shortly, the president has the power to submit constitutional amendments proposed by the parliament to a popular referendum. Before 1982, the parliament could, acting alone, change the constitution. According to the number of majorities in parliament that adopted the law on constitutional amendments, the president can exercise this power either voluntarily or compulsorily. Here, the president's referendum power in Turkey should be accepted in the category of limited power and evaluated with 2 points in terms of specific laws.

\subsection{Package Veto/Override and Partial Veto/Override}

Shugart \& Carey have dealt with the presidents' veto powers separately as partial and package veto ${ }^{234}$. Özsoy Boyunsuz determined that one of the essential legislative powers envisaged by the new system is presidential veto power in the Turkish new form of government ${ }^{235}$. According to the proposal, 'The president may veto either an entire legislative package or partial section(s) of a single bill, and three-fifths of the parliament would be required to override such a veto' ${ }^{236}$. When the constitutional amendments were first proposed it was suggested that the president should have a much stronger veto power. It was planned veto power when constitutional amendments were the first draft proposal to be much stronger than the present day. This proposal has not been modified; however, a strengthened veto power has entered force compared to the past. The president of Turkey has got both Package and Partial veto authority. According to the constitution, the president shall send the laws that he deems, wholly or partially, unsuitable for promulgation, along with the justification, back to the Turkish Parliament for reconsideration in the same period (Art. 89).

234 See Appendix I for Shugart \& Carey's categories for Legislative Powers. Shugart \& Carey, 1992, p. 150.

235 Özsoy Boyunsuz, 2016, p. 77.

236 Özsoy Boyunsuz, 2016, p. 78. 
The president has discretionary appointment powers: chair cabinet meetings, veto powers over legislation, the central role in foreign policy, and a key role in forming the government in Category 2 at Siaroff's study ${ }^{237}$. To override the president's veto powers by parliament, a simple majority was adequate before the constitutional amendments. Thus, there were not any special majorities to override the president's veto. Shugart \& Carey stated that if a simple majority of a quorum can override the president's package veto powers, then the president's power is pointed out with 0 . In this case, the president's veto power is 1 point in partial vetoes ${ }^{238}$.

Metcalf's revised category the president's veto powers are made by override by a simple majority of a quorum is also 1 point. According to the revised categories, this score does not change if the president's veto power is both partial and pocket. Therefore, according to Metcalf's revised category, the Turkish president veto powers were 2 points before mentioned amendments.

Nevertheless, the president's veto power has been strengthened with the new constitutional amendments of Turkey. Accordingly, laws that the president considers inappropriate partially or entirely (except for laws amending the budget and the constitution amendments) if the parliament 'adopts the law sent back for reconsideration without any amendment with an absolute majority, the law shall be promulgated by the President of the Republic; if the Assembly makes a new amendment to the law, the President of the Republic may send the amended law back for reconsideration' (Art. 89). From now on, the President's veto can now be overridden with "with an absolute majority".

Shugart \& Carey have scored 1 point for package veto and 2 points for the partial veto in this category ${ }^{239}$. Metcalf has proposed a revised for this power's scoring. Veto power is essential for stable democracy and needs revision for the previous study's scoring. Metcalf proposed a revised, emphasizing the importance of veto power in terms of stable democracy. According to him, veto power gives a president the "opportunity to explain constitutional defects in the legislation, to rally public opinion, or to call in

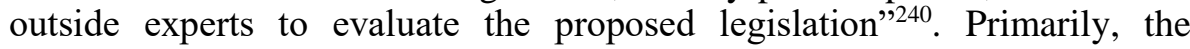
president's powers in both types of vetoes should be expressed with every 2 points in Turkey, based on the revised scores proposed.

237 Siaroff, 2003, p. 305.

238 Shugart \& Carey, 1992, p. 150.

239 Shugart \& Carey, 1992, p. 150.

240 See Appendix II for Metcalf's revised categories. Metcalf, June 2000, p. 670. 
Consequently before the constitutional amendment there was not an override power scoring for president package veto and it was 1 point for partial veto. Now the veto powers are considered with 3 points with the changes ${ }^{241}$. The president's veto powers increased from 1 point each in terms of both veto powers. The president veto powers are 4 points after the constitutional amendments in Turkey according to the revised category of Metcalf's scoring $^{242}$. To determine the position of the President, the level of competence of the authorities, and to show the system's transformation, it would be appropriate to base Metcalf's rating in this section.

\subsection{Decree}

Various presidents are not only chief executives, but they are also legislators to certain extent. Latin America increased the policymaking power of presidents ${ }^{243}$. Decree power is one of the critical policymaking tools for the President. This power is considered as the ability to make the president of the law. Decree power is divided into delegated decree and constitutional decree power. The first refers to the authorization to issue a decree to the executive within the legislature's framework of an "authority law". The second is recognising the power to regulate certain areas by decree directly to the executive branch through constitutional power-sharing ${ }^{244}$. Similarly, presidents' legislative powers are based on whether there are delegated or constitutional powers by Shugart \& Carey ${ }^{245}$. The 2017 constitutional amendments have been passed from the delegated decree power of the council of ministers to the constitutional decree power of the president. Carey and Shugart explained the constitutional decree power as "some executives are endowed by constitutions with authority to initiate policies by decree, and they are given this authority apart from any delegation of authority by statute". Then they separated the authority such as emergency powers and standard decree power ${ }^{246}$.

241 Shugart \& Carey, 1992, p. 150.

242 Metcalf, June 2000, p. 665.

243 Bulmer, Elliot, Presidential Legislative Power, International IDEA Constitution-Building Primer 15, International Institute for Democracy and Electoral Assistance (International IDEA), 2017, p.7.

244 Eren, 2019, pp. 1-72.

245 Shugart \& Carey, 1992, p. 132.

246 Carey, J. M., \& Shugart, M. P. Calling out the Tanks or Filling out the Forms? In J. pp. 134. M. Carey, \& M. P. Shugart (Ed.), Executive Decree Powers, New York: Cambridge University Press, p. 13. 
These decree powers, which are more advanced than the President's authority to submit the bill, are defined as "a decree-law is not merely a bill introduced by the executive, but rather a law or regulation issued by the executive". Furthermore, a decree power contains "only those laws that the president can initiate and maintain the force of law unless specifically rescinded (vetoed) by congress are meaningfully called decree laws" ${ }^{\prime 24}$. Thus, one of the powers dealt with to preserve the president's institutional authority of the heads of state is decree powers ${ }^{248}$.

This power is defined as 'a decree is simply law made by the executive and not subject to congressional review'. If the presidents' decree powers are a reserved authority and rescission is not in question, the president is highly powerful in this matter, and the powers score is stated as 4 . If the president has temporary decree power with few restrictions, the power score will be 2 according to Shugart \& Carey category. The other scores and categories of the Shugart \& Carey's are shown in Appendix I. If the President has temporary decree power with few restrictions, the score will be $2^{249}$. Decree powers lead presidents to "shape legislation and obtain laws that congress on its own would not have passed". According to Mainwaring and Shugart, the power of presidents plays an essential role in shaping legislation. It states that it depends on three reasons. These are; "unlike a bill passed by congress, a presidential decree is already law, not a mere proposal before the other branch has an opportunity to react to it; presidents can overwhelm the congressional agenda with a flood of decrees, making it difficult for Congress to consider measures before their effects may be difficult to reverse; and presidents can use the decree power strategically, at a point in the policy space where a congressional majority is indifferent between the status quo and the decree ${ }^{250 "}$.

Information on the provisions of the constitution on presidential decrees in Turkey was given above. The principles of the president's decrees should be briefly stated here since the discussion is whether there are limits on the president's power to issue decrees. Limits the power of the decree to the President according to the amendments to the Constitution; President "may issue presidential decrees on the matters regarding executive power" (Art. 104/17-1). "The fundamental rights, individual rights and duties included in

247 Shugart \& Carey, 1992, p. 140-143.

248 Martínez-Gallardo, C. Designing Cabinets: Presidential Politics and Ministerial Instability, Journal of Politics in Latin America, Vol. 6(2), pp. 3-38, p.17.

249 Shugart \& Carey, 1992, p. 150.

250 Mainwaring, \& Shugart, 1997, p.464. 
the first and second chapters and the political rights and duties listed in the fourth chapter of the second part of the Constitution shall not be regulated by a presidential decree" (Art. 104/17-2). "No presidential decree shall be issued on the matters which are stipulated in the Constitution to be regulated exclusively by law" (Art. 104/17-3). "No presidential decree shall be issued on the matters explicitly regulated by law" (Art. 104/17-4).

It should be noted that only the limitation specified in the fundamental rights, freedoms, and executive authority is apparent, as expressed as limits in the relevant Articles. The Constitution clearly states the hierarchy between legislative and executive procedures. Accordingly, 'In the case of a discrepancy between provisions of the presidential decrees and the laws, the provisions of the laws shall prevail'. Also, the Constitution with the provision of 'A presidential decree shall become null and void if the Grand National Assembly of Turkey enacts a law on the same matter' stipulated that the legislature may nullify the president's decrees by law. Thus, the decrees are subject to constitutional control ${ }^{251}$.

It is necessary to realize the assumption that laws and decrees will conflict in any case. Furthermore, although the hierarchical relationship between law and decrees has been expressed, other constitutional limitations are unclear. As mentioned earlier, neither the exclusive law areas in the constitution defined nor the "matters explicitly regulated by law" limit are clear. Meanwhile, President "may issue by-laws to ensure the implementation of laws, provided that they are not contrary thereto".

The constitution also specifies exclusive areas in which the President may only regulate by presidential decrees. In other words, except for issues related to the executive, some areas will be regulated only by presidential decrees. These exclusive presidential decrees areas; "appoint and dismiss the high ranking executives, and shall regulate the procedure and principles governing the appointment thereof; the functioning of the State Supervisory Council, the term of office of its members, and other personnel matters relating to their status shall be regulated; the organization and duties of the General Secretariat of the National Security Council shall be regulated and the establishment, abolition, the duties and powers, the organizational structure of the ministries, and the establishment of their central and provincial organizations" shall be regulated by the presidential decrees.

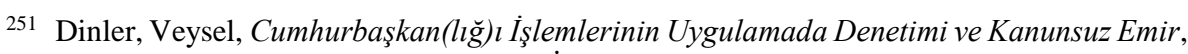
Kamu Hukukçuları Platformu, İstanbul, Retrieved 5 10, 2019, from http://www.kamuhukukculari.org/upload/dosyalar/Veysel_Dinler.pdf. 
Another decree power of the President concerns the cases in which he declares an emergency. President "may declare a state of emergency in one region or nationwide for a period not exceeding six months" (Art. 119). The President, alone, may declare an "emergency" depending on the reasons ${ }^{252}$ set out in the Constitution. With this emergency announcement by President, he also may issue emergency decrees in all areas, including fundamental rights and freedoms, regardless of the limitations of the usual presidential decrees above. In the event of a state of emergency, the president "may issue presidential decrees on matters necessitated by the state of emergency, notwithstanding the limitations outlined in the second sentence of the seventeenth paragraph of Article 104". Such decrees "which have the force of law shall be published in the Official Gazette and shall be submitted for approval to the Grand National Assembly of Turkey on the same day". However, except in the case of inability of the Grand National Assembly of Turkey to convene due to war or force majeure events, presidential decrees issued during the state of emergency shall be debated and decided in the Turkish Parliament within three months. Otherwise, presidential decrees issued during the state of an emergency shall be annulled automatically (Art. 119/7).

The president is granted the right to issue binding decrees and shall not dispute the laws and Constitution. This is similar to the Russian President's decree power specified in Art. 90 of the Russian Constitution ${ }^{253}$. The TC is more similar to Latin American presidential regimes, such as Chile, Columbia, Brazil, and Russia ${ }^{254}$. Similarly, Eren pointed out that the presidential decrees in Turkey are similar to those of Russia and Azerbaijan. The authority of the decree directly derives from the constitution; it is not based on legislative power (it is not delegated from parliament); it is lower than the law in the hierarchy of norms. The constitutional courts control it as they have a legislative function in this model. According to the author, "it is clearly stated that presidential decrees cannot be contrary to the laws and that the Constitutional Court will supervise their compliance with the law in these countries" ${ }^{255}$.

252 These reasons have been increased with the 2017's amendments. It has also been largely made open for comment. Therefore, it is a matter of appreciation for the execution to declare a state of emergency. See Article 119/1 of TC.

253 Metcalf, 1996, p. 135.

254 Metcalf, 1996, p. 137.

255 Eren, 2019, p. 9. 
Gönenç \& Kontac1 pointed out that the decree powers of the President are also a remarkable issue within the new system. They also drew attention to the president's power during the state of an emergency, and the President can issue "Extraordinary Presidential Decrees". Generally, the amendment to the relevant provision of the Constitution (Art. 119) will strengthen the constitutional status of the President during an emergency regime ${ }^{256}$.

Legislation based on decree regulation, according to Gözler, states that "1- The President of the Republic may not issue presidential decrees on matters not regarding executive power. 2- The fundamental rights, individual rights, and duties included in the first and second chapters and the political rights and duties listed in the fourth chapter of the second part of the Constitution shall not be regulated by a presidential decree. 3- No presidential decree shall be issued on matters stipulated in the Constitution to be regulated exclusively by law. 4- No presidential decree shall be issued on matters explicitly regulated by law (Art. 104)"257. However, a specific law field does not define in the TC. Besides, the limitation of the case where the law explicitly regulates a subject is unclear.

Therefore, the president's decree power can be considered at least 3 points in Turkey's scoring of influential presidents with new constitutional amendments. The maximum power of presidents is expressed with 4 points ${ }^{258}$. They distinguished between two variants of decree power granted to presidents. At this point, the decree power falls under the first variant of the president in Turkey. This is "the constitutional authority to legislate by decree in specified policy areas, whereby the decree is a law unless it is overturned by congress" $" 259$. The president's authority to issue a decree has not been complete 'no rescission' in Turkey. However, it should not refer to issue a decree as a minimal authority. Also, the legislature will not be able to act by law in areas related to the issue of executive such; procedure and principles governing the appointment of high ranking executives (Art. 104/9). This issue can only be addressed by presidential decree. Although the comparative tables given at the end are rated based on the scores of the Authors, under certain limitations, the authority to issue decrees given to the president should be considered as at least 3 points on the scale of Shugart \& Carey $^{260}$. Besides, the

256 Gönenç \& Kontac1, 2019, p. 76.

257 Gözler, 2018, pp. 369-370.

258 Shugart \& Carey, 1992, p. 150.

259 Shugart \& Carey, 1992, p. 140.

260 Shugart \& Carey, 1992, p. 150. 
president is solely authorized in terms of decrees issued in emergencies. Thus at this point, the power of the president in Turkey in both the usual and the extraordinary periods should be considered a revise in the work of the authors ${ }^{261}$. At this point, the president has reserved powers to issue decrees, but there are a few rescissions. In this case, it should be shown by 3 points.

\subsection{Exclusive Introduction of Legislation (reserved policy areas)}

Under this authority, presidents 'where the assembly is barred from considering legislation in certain policy areas unless the president first introduces a bill, the president possesses a powerful agenda-setting power' is stated as another legislative category. In Turkey, the president does not have the authority to introduce a bill. However, the president is required to decide exclusively by decree for specific policy areas as stated in the title of the decrees above.

Members of parliament are authorized to propose laws; a single deputy can propose a law in Turkey. Also, the president has a political party, and his party will likely be in parliament. Since political parties are disciplined parties, decisions can be taken to make any proposed law within the party in Turkey. In this way, the president can quickly provide the proposal of the law through his party. Besides, the TC Constitution grants the president's powers of initiative in budgetary matters (Art. 161). Thus, a single member of parliament from the president's party is authorized to propose legislation. At this point, the president does not have exclusive power, and his score is 0 in Turkey since we reserve these reserved policy areas heading as a field that can only be used with the law. However, the president's authorisation score will be greater if the exclusive areas left in executive areas are not limited to the "legislative proposal". For that reason, as mentioned earlier, the president has exclusive decree areas.

\subsection{Budgetary Powers}

Regardless of the system of government, the executive branch is usually in charge of the budget. However, the approval of the budget is carried out by the parliament. The most authoritative president in this category is explained as "President prepares budget; no amendment permitted". The president is highly authorized in the budget with the new constitutional amendments in Turkey. President shall submit a budget bill to the parliament at least seventy-

${ }^{261}$ Shugart \& Carey, 1992, p. 150. Metcalf, 2000. 
five days before the beginning of the fiscal year. (Art. 161/3) Members of the parliament may express their opinions in the Plenary on budgets of public administrations during the debates on each budget; however, they shall not propose that entail an increase in expenditure or a decrease in revenue. Besides, the appropriation granted by the central government budget shall indicate the limit of expenditure allowed.

"No provision shall be included in the Budget Act to the effect that the limit of expenditure may be exceeded by presidential decree" by the President's decrees. It should be noted that the power of the parliament to approve the budget has been dramatically reduced, compared to the situation/position before the constitutional amendment. The President's budget is "cannot be put into force within due period, and the provisional budget law shall be enacted". In this case, it can be considered that create a temporary budget to avoid the paralysis of public services. However, the assembly "if the provisional budget law cannot also be enacted", in this case, "the previous year's budget shall be applied increasingly as per the revaluation rate until the new budget law is adopted". Therefore, it is not crucial for the President that parliament does not approve the budget. However, the president does not have to get along well with the parliament to adopt his budget. At this point, it is appropriate for the president to be in the category of the most influential presidents in terms of budgetary powers and to score with 4 points in the structure formed by the new system of government in Turkey.

\subsection{Judicial Review}

As mentioned in the 13th question above, there is an individual application with abstract concrete norm control in Turkey through constitutional justice. It should be noted here that the President holds a privileged place among those who can refer to the abstract norm among other applicants. For example, the verification of laws and constitutional amendments may be requested by only the President of the Republic or by one-fifth of the Assembly of Turkey members. The Constitution imposed limits on verification of these laws regarding applicants, application time and the Court's review power. Among the applicants, now two political party groups have the largest number of members in the Turkish Parliament. These two parties can only be filed in the constitutional court to control the laws "in essence" point of view (Art. 148/2, 150). The president has been privileged in this regard. It should be stated that the authority score should be at least 2 in this regard. The powers of the President in Turkey are examined according to 
the countries where the most powerful presidents are positioned, and the results in the following figure are revealed.

The subject of judicial review will be incomplete without revealing the status of the judiciary in the new system. Therefore, it is necessary to mention the judicial body briefly. Some of the constitutional amendments have projected changes in the structure of the Council of Judges and Prosecutors ${ }^{262}$. In recent times partial or significant changes regarding judiciary have been involved in several recent constitutional alterations in Turkey. The President of the Council is the Minister of Justice. The Undersecretary to the Ministry of Justice shall be an ex-officio member of the Council (Art. 159/3) ${ }^{263}$. The president appoints minister and undersecretary, and they are responsible to the president ${ }^{264}$. In total, the president appoints six of the members of the Council through various methods. The Parliament elects the remaining seven members from the candidates meeting the criteria set by the Constitution. The executive organs can determine assignments, selection, appointment, and personal rights in the jurisdiction. However, in democratic regimes based on the principle of the separation of powers, the executive power is not granted such authorities to be singlehandedly enjoyed in the formation of independent and objective jurisdiction. Depending on the change of the president's role in the executive organ, the outcome becomes essential. In case the party-member president holds the majority in the assembly - as is now -the management of jurisdiction in terms of this Council laying the foundation of the independence and objectiveness of jurisdiction will depend upon the preferences of a single party ${ }^{265}$. The changes in the judiciary actually represent a transformation in

262 TC Art. 159 is regulates the Council of Judges and Prosecutors. "Council of Judge and Prosecutors shall be established and shall exercise its functions in accordance with the principles of the independence of the courts and the security of the tenure of judges" (Art. 159/1).

263 Since the Undersecretary to the Ministry of Justice's staff has been annexed it has been decided that the deputy council minister will be ex-officio staff of the Board instead of Undersecretary by Decree No. 703.Turan, Menaf; Türkiye'nin Yeni Yönetim Düzeni: Cumhurbaşkanlığı Hükümet Sistemi, Social Sciences Research Journal, Volume 7, Issue 3, September 2018, pp. 42-91, p.80-81.

264 "Three members of the Council shall be appointed among first category civil judges and public prosecutors not having lost the qualification to be reserved in the first category and one member shall be appointed among first category administrative judges and public prosecutors not having lost the qualification to be reserved in the first category by the President of the Republic;" (Art. 159/3). For more details in the Article on the electoral methods of the Assembly see TC Art.159/3.

265 Ardıçoğlu; p.22. 
the long term on the body. The president's appointments to the Council of Judges and Prosecutor, Constitutional Court and other higher judicial bodies puts him in an imperative situation. In addition, the fact that the President would be tried by the Constitutional Court when the President is likely to have appointed some of its members (see below) may affect the independence and impartiality of the decision ${ }^{266}$.

The most critical criticism here is that the President is granted the power of member appointment despite the title of "party-member head of government", but the Council of State and Court of Cassation have no right to appoint a member to the Council ${ }^{267}$.

In its previous findings, the Commission also found that "in all cases, the council should have a pluralistic composition with a substantial part, if not the majority, of members being judges. Except for ex-officio members, these judges should be elected or appointed by their peers" 268 .

The Venice Commission is specified that "The judiciary has to be fully independent of the legislative and, especially, from the executive power and has to be able to check, and if necessary strike down, acts adopted by the parliament and the president. The draft amendments do not seem conducive to such a situation"269 on its Report regarding Amendments.

The Council's effect is maintained by increasing the share of members, who have been appointed by the President, in the total number of members

266 European Commission for Democracy through Law (Venice Commission), Turkey Opinion on the Amendments to the Constitution Adopted By The Grand National Assembly on 21 January 2017 and to be Submitted to a National Referendum on 16 April 2017, Strasbourg, 13 March 2017, Opinion No. 875/2017, CDL-AD(2017)005, p. 25. See also Venice Commission, Report on Judicial Appointments, CDL-AD (2007)028, § 29; See also the Report on the independence of the judicial system, Part I: the independence of judges, CDL$\mathrm{AD}(2010) 004, \S 32$.

267 Uzun, Cem Duran, 6771 No. lı Kanunla Anayasada Yargıyla İlgili Yapılan Düzenlemeler. Uyuşmazlık Mahkemesi Dergisi, V. 0, Issue 11, 2018, pp. 409-443.

268 It's because of the richness of legal culture there is no single model that can be applied in all countries. Commission declared that "while respecting this variety of legal systems, the Venice Commission recommends that states which have not yet done so consider the establishment of an independent judicial council or similar body". Venice Commission, Joint Opinion on the draft Law of the Judicial System and the Status of Judge in Ukraine, 2010, p. 8. https://www.venice.coe.int/webforms/documents/ =CDL-AD(2010)004e.16.02.2021. See also Uzun; p. 422.

269 Venice Commission, Opinion No. 875/2017, CDL-AD (2017)005, p. 25. 
and keeping the Minister of Justice and the Secretary of Ministry of Justice as the ordinary members of Council ${ }^{270}$.

In order to provide for the democratic legitimacy of the Judicial Council, other members should be elected by Parliament among persons with appropriate legal qualifications taking into account possible conflicts of interest ${ }^{271}$. Since the assembly consists of a combination of different ideologies and parties, the parties should agree with the member to be selected. However, since the President is solely authorized for appointing these members, the President has more advantages over the legislature the President has an advantage of the Parliament.

In the new system, jurisdiction is necessary for supervising the key actors in the system and the legal actions of these actors. These actors are undoubtedly the president and the ministers and vice presidents he appoints. On the issue of criminal responsibility of the President, the Deputy Ministers and the Ministers were mentioned in the study.

The president shall be judged only by the Constitutional Court with the title of Supreme Court. Appointing 12 out of 15 members of the Court is among the authorities of the President. The Constitutional Court judges the Deputy Presidents and Ministers for the crimes related to their duties. However, the mandate of the President shall end whenever convicted of a crime that prevents from being elected by the Supreme Criminal Tribunal. Thus, the sentenced president or ministers may remain in office ${ }^{272}$. In this case, as stated by Esen, a president losing his/her legitimacy but remaining in the office despite the decision of a vast majority of assembly would create a regime crisis, and this would not comply with the soul of a liberal democratic regime $^{273}$. There are examples in which the Presidents have been allocated such power of appointment. However, in terms of the check-balance relationships between the legislative and executive organs, the appointments made by the President are generally subject to the approval of the legislative $\operatorname{organ}^{274}$.

270 Esen; 2016, p. 67.

271 Venice Commission, 2010, p. 8.

272 Gözler, Türk Anayasa Hukuku, p.98.

273 Esen, 2016, p. 60.

274 Erdoğan, 2016, p. 8. Gönenç \& Kontac1, p. 70. Uzun; p. 17. 
Besides the judicial organs, President also appoints officers to various institutions and organizations. There is no limit to this authority. However, in the pure form of presidential systems, the appointments, especially those to critical positions, are supervised by another power and a balance is established between the powers ${ }^{275}$.

In practice, the Senate approval process for executive branch officials and judges plays a crucial role in constraining the President. This power not only allows the Senate to exercise influence on the personnel who occupy these positions, but it also allows the Senate to use the appointments process to discipline the President and the executive branch and to express disapproval of any Presidential policies and practices with which the Senate disagrees, through the refusal to confirm appointments ${ }^{276}$.

Some of the authorities granted to the Presidents are not seen even in the Latin American type of presidential government. On the contrary, the president is strengthened by weakening the legislative and judicial organs ${ }^{277}$. This situation can be seen in the scores of both cases regarding the authority comparisons.

In order to strengthen the principle of the state of law, some of the transactions that have been outside the judicial review have been opened to judicial control. However, it was a necessity since the rule of countersignature in the executive organ has been removed. As a deviation from the state of law, there are still several transactions out of the judicial review in the Constitution, even at a limited number. Since it is the main guarantee of fundamental rights and freedoms, the Constitution has warranted the independence and objectiveness of jurisdiction. However, regarding the case exemplified above, an independent and biased jurisdiction becomes a completely non-functional instrument and does not warrant the rights and freedoms.

The President has been generously empowered relative to the powers of both the Parliament and the judiciary ${ }^{278}$. As a result, constitutional amendments could not balance the legislative, executive and judicial powers based on their control over each other.

275 Esen, 2016, p. 62.

276 Venice Commission, CDL-AD (2017)005, 101, p.24.

277 For evaluation hyper presidentialism in Latin America. Erdoğan, 2016, p. 11. Özbudun, 2015, p. 3-4. Özsoy Boyunsuz, 2016. Esen, 2016, p. 54.

278 Esen, 2016, p. 71. 
The military judiciary was abolished with amendments. Some actions that are outside of control have been opened to judicial review (Art. 125/2) to strengthen the principle of the rule of law. However, this change has already been required because the counter-signature rule has been removed in execution. Judicial oversight of certain transactions is still protected as a deviation from the rule of law, albeit limited in the Constitution. The rule (Art. $159 / 10)^{279}$ that prohibits applying to judicial authorities against decisions of the HSK other than those related to the professional penalty is still protected.

Özbudun pointed out that adopting constitutional amendments would result in a super presidency and competitive authoritarian regime, especially in the reconstruction of jurisdiction ${ }^{280}$. In our opinion, rather than naming the system in Turkey as an exact "super presidentialism" or "presidentialism", it should be named a system quasi "super presidentialism". Because, in terms of authorities, check and balance, and mutual interaction instruments, it is far from "presidential-like" but more similar to a "super presidential" system. The president's powers are not contested by the presidency but by the super presidency.

The presidential decree would be unconstitutional when it passes beyond the executive prerogative and enters into the legislative prerogative in terms of the effect on the fundamental rights and freedoms. From this aspect, considering the substantial effects, every regulation shall be subject to judicial review.

The study is enriched with data from similar studies in the following comparative data tables. The below tables of comparative data enriched with the data of similar studies on this topic. These tables included the adaption of the new form of government in Turkey inspired by relevant articles. Alongside incorporating Shugart and Carey's power ratings, Metcalf scored the presidential powers of some specific countries. Based on the current research results, the following comparison countries with the most powerful presidents were presented here. The appearance was firstly based on the president's powers in the new system, in accordance with the article of Metcalf. Secondly, depending on the comparison of the scores of presidents with the most authority. The data obtained from the above comparison illustrated below, it designed individually for both legislative and non-legislative powers. Lastly,

279 Esen, 2016, p. 69.

280 Özbudun, 2015, p. 9 ff. 
to see the enormous alteration, the president's powers can be compared with the other study by calculating them in terms of the new system of government.

The legislative powers of the minister were exhibited below with a comparative logic. Findings demonstrated that the President in Turkey has more legislative powers than presidents in the pure presidential system of the United States, Russia, and Latin American countries, called super presidentialism and a hybrid form of government. The president legislative powers in Turkey appeared to be the closest to those of the president in Chile ${ }^{281}$.

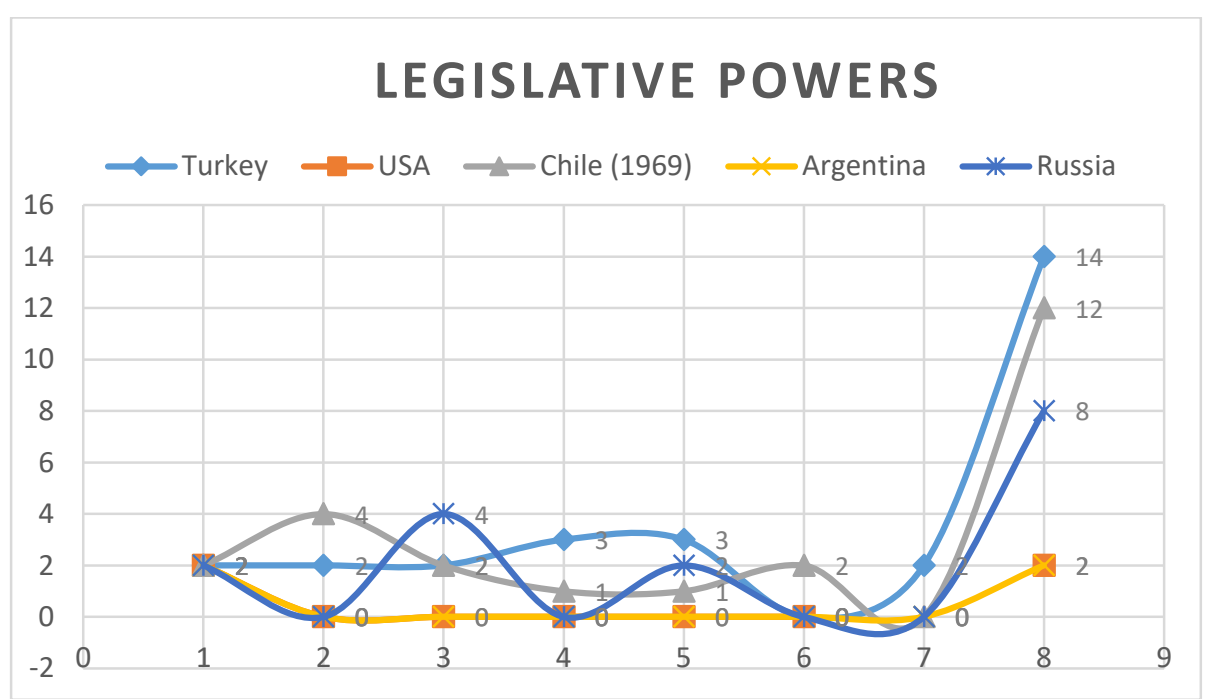

Figure 1. Analysing the president's legislative powers. Source: (Shugart \& Carey, 1992, p. 155), (Metcalf, 1996, p. 142) and Author.

\section{Non-Legislative Powers of the Turkish President}

The term "non-legislative powers" are constitutional limits placed on the separate origin and survival of the president and the parliament. Maximum separation of legislative and non-legislative powers are recognized as characteristic of presidentialism. Also, it is designed "to ensure that each branch could impose checks on the other without fear of jeopardizing its existence" $^{282}$.

\footnotetext{
${ }^{281}$ For further discussion about Chili's situation in terms of system of government see Özsoy Boyunsuz, 2016.

${ }^{282}$ Shugart \& Carey, 1992, p. 19. Metcalf, 2000, p. 127.
} 
Separation of powers and the rule of law must be esteemed. This necessitates adequate checks and balances inherent in a designed political system with democratic, sustainable elements. Every constitution is a different and complex way of checks and balances. Each rule needs to be examined because of its merits for the balance of powers as a whole ${ }^{283}$. These main issues are mostly connected with the executive organ. For that reason, presidential scores of the Turkish President's non-legislative powers are vital as much as legislative powers. Shugart \& Carey asserted that the nonlegislative powers are contained by the exercise of the president's powers. According to the authors, cabinet formation, cabinet dismissal, censure and dissolution of parliament are occurring under non-legislative powers classification $^{284}$. The executive organ has become uniform and removed the powers of the parliament, such as censure through amendments in the recent system of the government in Turkey.

\subsection{Cabinet Formation}

Studies on this topic observe how cabinet positions are filled and how ministers or entire cabinets are removed. It signifies whether the other members of the executive are responsible to the president, the assembly, or both. The question of how a cabinet is formed refers to a separate dimension of the matter. The authors considered the impeachment of the Cabinet to be more powerful than the authority to establish $\mathrm{it}^{285}$. Vice presidents and ministers are no longer responsible to the parliament under the current system of the government. They are politically responsible to the president solely. Vice presidents are particularly liable to the Assembly on their criminal responsibilities, but still in case of a crime related to their duties.

They are subject to legislative immunity from personal crimes. The president's authority in appointing ministers is separated from the most powerful presidents if they have been adopted without the parliament's approval. In addition to the consistent execution of the new regime, and Constitution ruled that "The deputies of the President of the Republic and the ministers shall be appointed from among those who are eligible to be a deputy and removed from office by the President" (Art. 106/4). The President alone makes all appointments in the Executive without exception. President even appoints the vice president who will act as president and use all his powers without exception. An appointed deputy of the President is free to exercise

\footnotetext{
${ }^{283}$ Venice Commission, Opinion No. 875/2017, CDL-AD (2017)005, § 124

${ }^{284}$ Shugart \& Carey, 1992, p. 150.

${ }^{285}$ Shugart \& Carey, 1992, p. 118-119.
} 
any authority without limitation and without being selected. Art. 106 of the Constitution stated that "In cases where the President of the Republic is temporarily absent from his/her duties on account of illness or travelling abroad, the deputy president acts as the President of the Republic and exercises his/her Powers". The power of the President in this regard is without a doubt 4 points.

\subsection{Cabinet Dismissal}

The president's powers are critical in the removal of ministers. The current system establishes that the President dismisses the ministers with his own will (Art. 104). It should be noted that they scored the most competent presidents with 4 points. In his revised proposal on powers in this field, Metcalf defined the president's authority on the minority of ministers as 'President dismisses ministers with the consent of assembly' according to the presidential powers expressed by 3 points ${ }^{286}$. The powers to appoint and dismiss ministers and deputies are the absolute powers of the President. They have privileged powers in the dismissal as well as in appointment in an executive organ. If only the criminal liability of the minister and his minister is the matter with a complicated method, they can be reconstituted by parliament. Even in this case, they can remain in office. The deputies of the President of the Republic or ministers 'who are convicted of a crime by the Supreme Criminal Tribunal "for a crime that prevents them from being elected" (Art. 76/2) shall lose their mandate' (Art. 106). This method has been complicated, and it almost has the same difficulty as the power to change the constitution without a referendum.

\subsection{Censure}

In this case, the parliament may not censure and remove the cabinet or ministers, which means the president is powerful in the case of the system of government. In such cases, the score to be given to the power of the president is 4. In Turkey, parliament only absolute majority of the Turkish Parliament may table a motion requesting that the deputies of president and ministers be investigated on allegations of perpetration of a crime regarding their duties. This matter is limited to criminal responsibility for the duties of ministers and the deputies of the president. Their political responsibilities are only against the president. Legal responsibilities are based on the principle "Recourse to judicial review shall be open against all actions and acts of the administration"

286 Metcalf, 2000, p.670. 
of Art. 125 of the Constitution. In addition, the Turkish parliament may not censure and remove ministers. In this case, the authority of the President is 4 points.

\subsection{Dissolution of Assembly}

The authority to the dissolution of the parliament of the President was accepted as an absolute authority under the new amendments. The President can dissolve the parliament without being bound to any conditions. Shugart \& Carey stated that there was a difference between the dissolution unreserved power of the president and the requirements of the new presidential election with the exercise of this dissolve power ${ }^{287}$. This authority is unconditional and unlimited. The president is scored with 4 , but as in the new form of government in Turkey, as a result of the dissolution of the parliament of the president required new presidential elections are scored with 2. Presidential elections and parliamentary elections are held together on the same day with the new constitutional amendments. In Siaroff's study, in some similar models, elections are made together in Category 2 such as Brazil, Chile, Namibia, Argentina, and many others ${ }^{288}$.

Considering that the Presidency and the majority of the Turkish Parliament are likely to be won by the candidates of the same party, it was made in order to ensure the 'stable' and 'efficient' operation of the system on the same day of elections. However, Gönenç and Kontacı have drawn attention to the fact that the opposite results appeared in Guatemala in 1990, In Ecuador in 1997, and finally at the elections of Peru in $1990^{289}$. The president and the parliamentary majority emerged from different parties in the elections held together in these countries ${ }^{290}$.

At this point, the unconditional power of dissolution of the parliament has entered the Turkish constitutional system as one of the critical powers of the president. The President of the Republic may decide to renew the elections. ${ }^{291}$ There is no provisional boundary to exercise this power. In the case that the president's decision to dissolve parliament is applying elections,

\footnotetext{
${ }^{287}$ Shugart \& Carey, 1992, p. 154.

${ }^{288}$ Siaroff, 2003, p. 296.

289 Gönenç \& Kontac1, 2019, p. 76 ff.

290 For a study that discusses these examples, see Esen, 2016, 47 ff. Gönenç \& Kontac1, 2019, p. 66.

291 Renewal of Election of the Grand National Assembly of Turkey and the Presidential Election 15 Article 116- (As amended on April 16, 2017; Act No. 6771).
} 
it indicates the less competent ability of the president in terms of termination of the powers of the president studies.

One of the issues to be discussed is that the co-existence of both parliament and presidential elections can be criticized for the separation of powers. Meanwhile, considering the president is a member or president of a political party, there is doubt that two different parties may be winners in the same elections. Another critique is that when the parliament decides to abolish itself, it is necessary to accept at least 360 deputies out of 600 deputies - the three-fifths majority of the total number of its members. Indeed, there may be hesitancy for the president who knows that his elections will be renewed while exercising this authority. However, it is not a complete bound in terms of starting to exercise authority. It is also clear that a president who will never be elected will not feel this hesitancy. In other words, for a president who is in his second and last term, there will be no limitation of this authority. One of the things to discuss is that a balance is in favour of the president in terms of balancing the powers except for the separation of powers. Here except for the separation of powers debate, the powers are balancing in favour of the President. Although it is foreseen that presidential elections will be held when the assembly decides to abolish itself, the balance described above is not considered in implementing these decisions. A qualified majority is required for parliament to decide to abolish itself. However, the president can take this decision unconditionally on his own.

The government failed to win a vote of confidence or failed to form a government before the constitutional amendment (old version of Art. 116). Today, both parliament 'may decide to renew the elections by a three-fifths majority of the total number of members', and 'President may decide to renew the elections, the general election of the parliament.' In both cases, the general election of the parliament and the presidential election shall be held together. Metcalf has not reviewed the list and scored, and he revised some of them to exercise these powers ${ }^{292}$. It is also necessary to note that there is a difference between the president's ability to exercise this power independently, with the support of a significant majority in parliament.

In terms of those who have low scores of these powers, the following points in Turkey should also be noted. The political parties are strongly disciplined, and the president is both the head of state and the leader of his political party. Cheibub stated that "the separation of powers that characterizes presidentialism, on the contrary, implies low levels of party discipline. Even

292 Metcalf, 2000, p. 127. 
a president is lucky enough to belong to a party that controlled a majority of congressional seats could not necessarily count on the support of that majority when governing" 293 . The AKP party, which the president is currently chairing, also has a majority in parliament today. This majority, with the support of a more minor party, carried out these constitutional amendments. Goplerud and Schleiter draw attention to the different possibilities between the initiative of this authority, the emergence of the intermediating when the authority comes up, and the final exercise of the authority. They draw attention to the variance between the power of the president's ability to dissolve parliament and the ability of a three-fifths majority of parliament to exercise that authority ${ }^{294}$. This is the current situation in Turkey. Today, the opposition parties of parliament are expressing their desire for early elections. However, it is impossible to decide if the president's party, which has a majority in parliament, does not support it. Indeed, the president has no limitations as an actor who has initiated to exercise that authority. It should also be noted that the president has a strong agenda-setting power in this circumstance. Moreover, the requirement of making his own elections will not set an essential limit on this authority for a second-term and last-term president. As a result, the President may dissolve the "at-will" parliament without any circumstances.

Another dimension of the dissolution power of the parliament is that to show that the new system of government is not a pure presidential.. The strict separation of powers refers to the executive, and legislative powers do not originate from each other and cannot end their existence. However, in super presidential systems, the principle of separate survival is obviated. Shugart \& Carey mentioned three ways in which the separation of origin and survival was limited in some systems. Accordingly, these systems are; assembly involvement in the appointment of cabinet ministers, the censure of the cabinet ministers by the assembly, and the dissolution of the assembly by the president.

The authority to dissolution is regarded as an intermediate for the deadlock that may arise in the legislature. There are also criticisms of this instrument not being in pure presidential systems. It is also clear that the forces' source and survival should not depend on each other in the separation of powers. When this authority is exercised in presidential systems, the new parliament may still have hostility towards the president who will remain in

293 Cheibub, 2007, p. 10.

294 Goplerud, M., \& Schleiter, P. An Index of Assembly Dissolution Powers, Comparative Political Studies, Vol. 49(4), 2016, pp. 427-456, p.403-432. 
office. This leads to the possibility of the persistence of the deadlock problem, even arising an antagonized parliament. In presidential cabinets, the president remains head of government even if a hostile parliament is returned after dissolution. In such a situation, the problem of deadlock is likely to remain or even to be antagonized. However, this possibility does not seem to have disappeared due to the co-existence of elections in the Turkish system. Suppose the new parliament is the same as the political majority of the parliament before its abolition, and the same president is elected. In that case, if he is not the last term, as a result of the elections held together, the deadlock will appear again.

Namibia, Weimar and Sri Lanka are presented as similar models of Turkey's dissolution of parliament by Shugart \& Carey. In Namibia, "a president who dissolves the assembly stands for re-election concurrently with new assembly elections". On the other hand, this case depends on a situation that if the parliament of the Namibian "repeatedly censures cabinets, presidents have the alternative of calling for new elections, but only if they are willing to face the electorate themselves" ${ }^{295}$. However, it should be noted that the new constitutional amendments of Turkey have abolished the censure implement. In other words, with the amendments of the constitution, ministers are now responsible to the president and not against the parliament. Altogether, by considering third type president-parliamentary system affairs is defined as "a common type with shared- or confused- responsibility for cabinets between president and assembly" as stated authors study ${ }^{296}$. Moreover, exercising this authority from a president who cannot be elected for a second time does not constitute a minimal authority. In light of these statements, we consider it appropriate to include Metcalf's " 3 points for Restricted by frequency or point within the term ${ }^{297 "}$ " revise with our proposal indeed. Regarding the result, the president's dissolution power is not more vital than the renewal of his own elections. The use of the dissolution power against parliament alone without a condition is not a boundary for acknowledged of the power of the president. The president's second term does not matter in any case. Thus, if the presidents can practice this power more effortlessly than the parliament at that time, the dissolution power of presidents may be accepted as 3 points.

In these reviews, the fundamental and the revised remarks on the powers of the presidents were discussed. It is necessary to identify that the new

295 Shugart \& Carey, 1992, p. 73.

296 Shugart \& Carey, 1992, p. 15.

297 Metcalf, June 2000. 
government that emerged in Turkey is not similar to other types of governments. This new model of government, which is put forward by constitutional amendments, is implemented not as a result of needs or necessities but entirely because of the preferences of political power. The powers in the field of non-legislative powers were examined and compared with the values of the countries where the most powerful presidents were present such as the USA, Chile (1969), Russia. Table 1 and the values used in which the figures were revealed were also given after Figure 2.

With the constitutional amendment, the demands for transformation in Turkey did not suddenly emerge. Instead, this transformation occurs gradually, but it never breaks legal continuity. Instead, it is realized with all the relevant actors' awareness about its impact on one or more Constitution's fundamental aspects. In brief, for Albert, a 'simple' amendment "must cohere with the existing constitution and must keep the constitution consistent with its pre-change form", while a constitutional dismemberment, ${ }^{298}$ either enhancing or weakening democracy, does not.

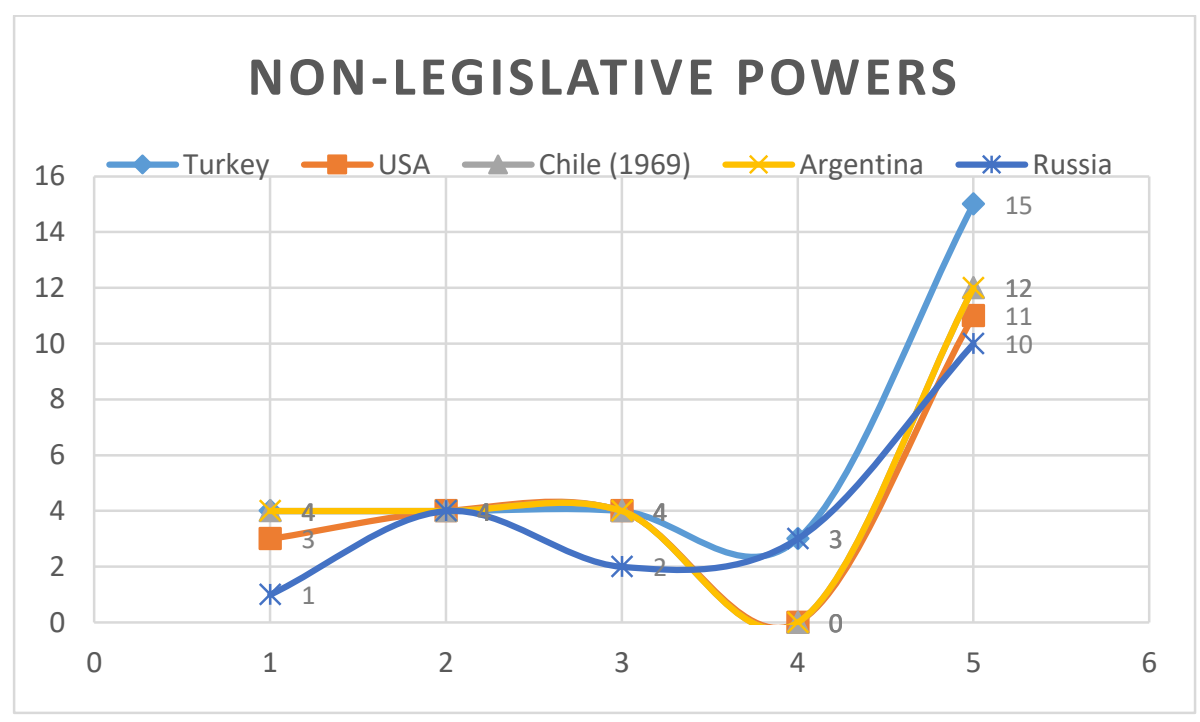

Figure 2 Analysing president's non-legislative powers Source: (Shugart \& Carey, 1992, p. 155), (Metcalf, 1996, p. 142) and Author.

298 Albert, Richard, Constitutional Amendment and Dismemberment, The Yale Journal Of $\begin{array}{llllll}\text { International Law } & \text { Vol. } & 43: & 1 & \text { p. } & 1 \text {, }\end{array}$ https://digitalcommons.law.yale.edu/cgi/viewcontent.cgi?article= $1685 \&$ context=yjil 


\begin{tabular}{|c|c|c|c|c|c|c|c|c|c|c|c|c|c|}
\hline \multicolumn{7}{|c|}{ Legislative powers } & \multicolumn{7}{|c|}{ Non-legislative powers } \\
\hline & $\begin{array}{l}0 \\
0 \\
0 \\
0 \\
\frac{0}{0} \\
0 \\
0\end{array}$ & 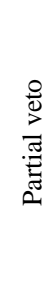 & 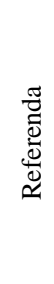 & 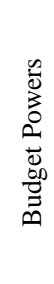 & 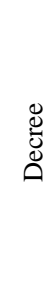 & 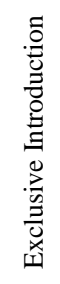 & 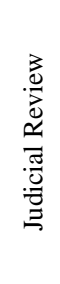 & לِ & 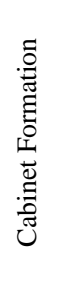 & 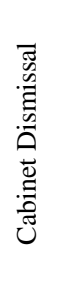 & 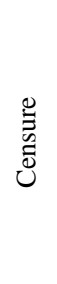 & 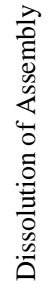 & 疍 \\
\hline Turkey & 2 & 2 & 2 & 3 & 3 & 0 & 2 & 14 & 4 & 4 & 4 & 3 & 15 \\
\hline USA & 2 & 0 & 0 & 0 & 0 & 0 & & 2 & 3 & 4 & 4 & 0 & 11 \\
\hline $\begin{array}{c}\text { Chile } \\
\text { (1969) }\end{array}$ & 2 & 4 & 2 & 1 & 1 & 2 & - & 12 & 4 & 4 & 4 & 0 & 12 \\
\hline Argentina & 2 & 0 & 0 & 0 & 0 & 0 & - & 2 & 4 & 4 & 4 & 0 & 12 \\
\hline Russia & 2 & 0 & 4 & 0 & 2 & 0 & 0 & 8 & 1 & 4 & 2 & 3 & 10 \\
\hline
\end{tabular}

Table 1. Comparison of Turkey's presidential powers. Source: (Shugart \& Carey, 1992, p. 155), (Metcalf, 1996, p. 142) and Author.

\section{Conclusions}

The present study expressed the presidential powers in the new government framework in Turkey and the countries having the strongest presidents. In addition, the data of the countries having the most powerful presidents have been added to this research for comparison to shed light on the high empowerment of the president in the new regime. Also, as an example of a pure presidential system, some data was added to the America comparison table.

The comparisons were made between the legislative and non-legislative power values of the studied countries. Moreover, while the president's powers in Turkey are being scored, the declarations of those countries with controversial topics are also stated under the relevant headings. The results demonstrated that the president has become quite powerful and even authorized from both Latin American hybrid presidential systems and Russian super presidentialism.

The Turkish type presidential system nourishes personal power. In this aspect, the application disclosures the form of a neopatrimonial, authoritarian regime, and the constitutional infrastructure provides for this. The principle of 
merit and impartiality in public administration is corrupted with this new system, as well as problems such as the dominant party structure, electoral system-higher election barrage etc. the creation of an effective management structure has been prevented ${ }^{299}$.

Furthermore, the study suggested that the legislative and non-legislative power values prevented the forces securing their independence. Therefore, stating the separation of forces was not possible, which is the basis of American presidentialism and formed by the founding fathers, existing in a regime with these principles. Accordingly, the possibility of both censure and dissolution encouraged cooperation between branches, as each anticipates the likely reaction of the others ${ }^{300}$. Finally, it is worth noting that the censure has been abolished; however, unconditional dissolution has been introduced according to Turkey's newly system of government. Thus, the first two conditions are not available in Turkey's new system; however, the authority unconditionally provides the president with the dissolved parliament.

It is worth comparing this study with democratic data. Since 2017, different institutional adoptions have not been made in Turkey's constitutional history. Besides, most studies pointed out that the democratic breakdown is more likely to happen in presidential regimes than in parliamentary ones. However, as Metcalf specified, the relationship between regime type and democratic breakdown may be more complex ${ }^{301}$. Likewise, Shugart \& Carey proposed that the analysis be done more accurately because the risk of democratic breakdown is not constant in states with popularly elected presidents.

As Esen declared with accuracy, a regime based on a system of government with weakened legislative and judicial bodies will be one of the dictatorial regimes that have come to the fore at every stage of history, no matter the name is. Notably, it means "giving up Turkey's democratic and constitutional gains" has accumulated since the 19 th century ${ }^{302}$. Also, by way

299 For a detailed study of the new system's problems and suggested solutions see. Özsoy Boyunsuz, Şule and Esen, Berk, Türkiye Iç̧ın Yeni Bir Hükümet Sistemi Hükümet Sistemi Kaynakl Sorunlar Ve Çözüm Önerileri, Politika Notu, İstanbul Politik Araştırmalar Enstitüsü, Aralık 2020, 018, retrieved from https://d4b693e1-c592-4336-bc6a36c134d6fb5e.filesusr.com/ugd/c80586_6a562ba050bb4af7b0acf37226c53109.pdf.

300 Shugart \& Carey, 1992, p. 106.

301 Metcalf, 1998.

302 In conclusion, powers were concentrated in the executive body of one person who is irresponsible both politically and criminally. Esen has noticed at the proposal stage of 
of Onar, Gönenç, Özbudun, Esen, Özsoy Boyunsuz, and many have argued, democracies cannot indeed be democracy without free and fair elections. They agree with Juan Linz that these regimes "are not democracies even using minimum standards". Consequently, to avoid confusion, adjectives should be added to "authoritarianism" rather than to democracy"303. Özbudun drew attention to the determination that "hybrid regimes as subtypes of democracy". So the new system in Turkey is neither the pure presidential nor the superpresidential form of government. However, it should be accepted that today the system returns to extreme examples of delegative democracy and degenerate presidentialism likewise Latin American cases. While this model has strengthened its unique structure to execution, it has envisaged a complex, hybrid, and untested form of government. We identified the new system as quasi super presidentialism; however, this will not go further than increasing concepts that describe almost the same phenomenon in the literature.

Nevertheless, it has been proven that the Turkish presidential system was adapted with the delegative/hyper-presidentialism model from the constitutional characters of amendments before the system took effect ${ }^{304}$. Nowadays, since the application accompanies this, it is very appropriate to call the system with such a naming. Identification of the system is like a dead end, and what matters is not naming it but revealing which undemocratic examples it looks like. Hyper presidential systems that have moved away from democracy should be monitored for sure. Whether the new system of government can be named hyper-presidentialism or not, as a result, to weaken

amendments, powers were concentrated in the executive body of one person who is absolutely irresponsible politically and criminally. Esen, 2016, p. 71.

303 Indeed, an even playing field is implicit in most procedural definitions of democracy, usually expressed as "free and fair elections". Consequently, the authors criticize the classification of "hybrid regimes as subtypes of democracy. [...] [T] he value of such labels is questionable." They agree with Juan Linz that these regimes "are not democracies even using minimum standards". Thus, to avoid confusion, adjectives should be added to "authoritarianism" rather than to democracy (15). In the authors' opinion, p. 43. Özbudun, Ergun, Turkey's Judiciary and the Drift toward Competitive Authoritarianism, The International Spectator, Vol. 50:2, 2015, pp. 42-55.

304 Özsoy Boyunsuz named the system through these key features. First absence of constitutional checks and balances on the presidential powers. Although highly empowered president legislature and judiciary are weak. The draft constitution does not offer separations of powers with including such dissolution of assembly, parliamentary immunity for ministers, and exclusive executive control over initiating budged proposals in order to empower executive authority. The proposed model is not offered a pure presidentialism. Özsoy Boyunsuz, 2016, p. 84. 
democratic institutions and eliminate democratic stability and effectiveness is essential.

Returning to the parliamentary system has started to be discussed again publicly and scholarly ${ }^{305}$. However, at the same time, the discussion about probable new constitutional amendments proposal that aims transformation to a pure presidential system started to occur. Therefore, rather than heading towards the systems in which we have no experience, it would be wiser to implement the parliamentary systems by strengthening them with the constructive vote of no confidence. Thus, executive stability can be achieved, and a government that will account for the parliament can provide Turkey with really "effective" executive power.

\section{Appendix A}

\begin{tabular}{|c|c|}
\hline \multicolumn{2}{|c|}{ Legislative Powers } \\
\hline $\begin{array}{l}\text { Package Veto/Override } \\
4 \text { Veto with no override } \\
3 \text { Veto with override requiring majority greater than } \\
2 / 3 \text { (of quorum) } \\
2 \text { Veto with override requiring } 2 / 3 \\
1 \text { Veto with override requiring absolute majority of } \\
\text { assembly or extraordinary majority } \\
\text { less than } 2 / 3 \\
0 \text { No veto; or veto requires only simple majority } \\
\text { override }\end{array}$ & $\begin{array}{l}\text { Partial Veto/Override } \\
4 \text { No override } \\
3 \text { Override by extraordinary majority } \\
2 \text { Override by absolute majority of whole } \\
\text { membership } \\
1 \text { Override by simple majority of quorum } \\
0 \text { No partial veto }\end{array}$ \\
\hline $\begin{array}{l}\text { Decree } \\
4 \text { Reserved powers, no rescission } \\
2 \text { President has temporary decree authority with few } \\
\text { restrictions } \\
1 \text { Authority to enact decrees limited } \\
0 \text { No decree powers, or only as delegated by } \\
\text { assembly }\end{array}$ & $\begin{array}{l}\text { Exclusive Introduction of Legislation } \\
\text { (reserved policy areas) } \\
\text { 4 No amendment by assembly } \\
\text { 2 Restricted amendment by assembly } \\
1 \text { Unrestricted amendment by assembly } \\
0 \text { No exclusive powers }\end{array}$ \\
\hline $\begin{array}{l}\text { Budgetary Powers } \\
4 \text { President prepares budget; no amendment } \\
\text { permitted } \\
3 \text { Assembly may reduce but not increase amount of } \\
\text { budget items } \\
2 \text { President sets upper limit on total spending, within } \\
\text { which assembly may amend } \\
1 \text { Assembly may increase expenditures only if it } \\
\text { designates new revenues } \\
0 \text { Unrestricted authority of assembly to prepare or } \\
\text { amend budget }\end{array}$ & $\begin{array}{l}\text { Proposal of Referenda } \\
4 \text { Unrestricted } \\
2 \text { Restricted } \\
0 \text { No presidential authority to propose } \\
\text { referenda }\end{array}$ \\
\hline
\end{tabular}

305 Özsoy Boyunsuz, and Esen, Aralık 2020, p. 24-36. Akartürk \& Sönmez, 2021. 


\begin{tabular}{|c|c|}
\hline \multicolumn{2}{|c|}{ Non-Legislative Powers } \\
\hline $\begin{array}{l}\text { Cabinet Formation } \\
4 \text { President names cabinet without need for } \\
\text { confirmation or investiture } \\
3 \text { President names cabinet ministers subject to } \\
\text { confirmation or investiture by assembly } \\
1 \text { President names premier, subject to investiture } \\
\text { who then names other ministers } \\
0 \text { President cannot name ministers except upon } \\
\text { recommendation of assembly }\end{array}$ & $\begin{array}{l}\text { Cabinet Dismissal } \\
4 \text { President dismisses cabinet ministers at will } \\
2 \text { Restricted powers of dismissal } \\
1 \text { President may dismiss only upon acceptance } \\
\text { by assembly of alternate minister or } \\
\text { cabinet } \\
0 \text { Cabinet or ministers may be censured and } \\
\text { removed by assembly }\end{array}$ \\
\hline $\begin{array}{l}\text { Censure } \\
4 \text { Assembly may not censure and remove cabinet or } \\
\text { ministers } \\
2 \text { Assembly may censure, but president may respond } \\
\text { by dissolving assembly } \\
1 \text { "Constructive" vote of no confidence (assembly } \\
\text { majority must present alternative } \\
\text { cabinet) } \\
0 \text { Unrestricted censure }\end{array}$ & $\begin{array}{l}\text { Dissolution of Assembly } \\
4 \text { Unrestricted } \\
3 \text { Restricted by frequency or point within term } \\
2 \text { Requires new presidential election } \\
1 \text { Restricted only as response to censures } \\
0 \text { No provision }\end{array}$ \\
\hline
\end{tabular}

Source: Shugart \& Carey (1992, p. 150).

\section{Appendix B}

\begin{tabular}{|c|c|}
\hline \multicolumn{2}{|c|}{ Revised List of Legislative Powers } \\
\hline Package Veto/Override & Partial Veto/Override \\
\hline 4 No override & 4 No override \\
\hline 3 Override by extraordinary majority & 3 Override by extraordinary majority \\
\hline 2 Override by absolute majority of whole & 2 Override by absolute majority of whole \\
\hline membership & memb \\
\hline 1 Override by simple majority of quorum & 1 Override by simple majority of quorum \\
\hline 0 No veto & 0 No partial veto \\
\hline $\begin{array}{l}\text { Decree } \\
4 \text { Reserved powers, no rescission }\end{array}$ & $\begin{array}{l}\text { Exclusive Introduction of Legislation } \\
\text { (reserved policy areas) }\end{array}$ \\
\hline 2 President has temporary decree & 4 No amendment by assembly \\
\hline authority with few restrictions & 2 Restricted amendment by assembly \\
\hline 1 Authority to enact decrees limited & 1 Unrestricted amendment by assembly \\
\hline $\begin{array}{l}0 \text { No decree powers, or only as delegated } \\
\text { by assembly }\end{array}$ & 0 No exclusive powers \\
\hline
\end{tabular}




\begin{tabular}{|c|c|}
\hline $\begin{array}{l}\text { Budgetary Powers } \\
4 \text { President prepares budget; no } \\
\text { amendment permitted } \\
3 \text { Assembly may reduce but not increase } \\
\text { amount of budget items } \\
2 \text { President sets upper limit on total } \\
\text { spending, within which assembly may } \\
\text { amend } \\
1 \text { Assembly may increase expenditures } \\
\text { only if it designates new revenues }\end{array}$ & $\begin{array}{l}\text { Proposal of Referenda } \\
4 \text { Unrestricted } \\
2 \text { Restricted } \\
1 \text { Countersignature of minister required } \\
0 \text { No presidential authority to propose } \\
\text { referenda }\end{array}$ \\
\hline \multicolumn{2}{|c|}{$\begin{array}{l}\text { Judicial Review } \\
4 \text { President alone refers } \\
2 \text { President, cabinet, or majority of assembly may refer } \\
1 \text { President, cabinet, or minority of assembly may refer } \\
\text { 0 President may not refer or no prior judicial review } \\
\end{array}$} \\
\hline \multicolumn{2}{|c|}{$\begin{array}{l}\text { Revised Lists of Non-Legislative Powers } \\
\end{array}$} \\
\hline $\begin{array}{l}\text { Cabinet Formation } \\
4 \text { President appoints ministers without } \\
\text { need for assembly confirmation } \\
3 \text { President appoints ministers with } \\
\text { consent of assembly } \\
2 \text { President names cabinet ministers } \\
\text { subject to confirmation or investiture by } \\
\text { assembly } \\
1 \text { President nominates prime minister, } \\
\text { who needs confidence of assembly; prime } \\
\text { minister appoints other ministers, } \\
\text { possibly with consent of president } \\
0 \text { President cannot name ministers except } \\
\text { upon recommendation of assembly }\end{array}$ & $\begin{array}{l}\text { Cabinet Dismissal } \\
4 \text { President dismisses ministers at will } \\
3 \text { President dismisses ministers with } \\
\text { consent of assembly } \\
2 \text { President dismisses ministers, but only } \\
\text { under certain conditions } \\
1 \text { President dismisses ministers on the } \\
\text { proposal of the prime minister } \\
0 \text { Ministers may be removed only by } \\
\text { assembly on vote of censure }\end{array}$ \\
\hline $\begin{array}{l}\text { Censure } \\
4 \text { Assembly may not censure and remove } \\
\text { cabinet or ministers } \\
2 \text { Assembly may censure, but president } \\
\text { may respond by dissolving assembly } \\
1 \text { "Constructive" vote of no confidence } \\
\text { (assembly majority must present } \\
\text { alternative } \\
\text { cabinet) } \\
0 \text { Unrestricted censure }\end{array}$ & $\begin{array}{l}\text { Dissolution of Assembly } \\
4 \text { Unrestricted } \\
3 \text { Restricted by frequency or point within } \\
\text { term } \\
2 \text { Requires new presidential election } \\
1 \text { Restricted: only as response to specific } \\
\text { events } \\
0 \text { No provision }\end{array}$ \\
\hline
\end{tabular}

Source: Shugart \& Carey (1992), Shugart (1996), and Metcalf (June 2000). 


\section{References}

Albert, Richard; Constitutional Amendment and Dismemberment, The Yale Journal Of International Law Vol. 43: 1 p. 1, https://digitalcommons.law.yale.edu/cgi/viewcontent.cgi?article=1685\&contex $\mathrm{t}=\mathrm{yjil}$

Aliefendioğlu, Yılmaz; Anayasa Mahkemesi Kararları Işı̆̆ında "Yokluk” Ya Da “Yok Isslem”, TBB Dergisi, No. 81, 2009.

Alkan, Haluk; Cumhurbaşkanlı̆̆l Sisteminin Kurumsal Özellikleri ve Demokratikleşme Sürecine Olası Etkileri, Türkiye İletişim Araştırmaları. Türkiye İletişim Araştırmaları Dergisi, 30-Medya ve Demokrasi,2018, pp. 139153

Akartürk, Ekrem Ali and Küçük, Tevfik Sönmez; Güçlendirilmiş Parlamenter Sistem Teori ve Uygulama, Adalet Yayınevi, 2021.

Anayurt, Ömer, and Ekinci, Ahmet; Tek Yapılı Yürütme Esasına Dayalı Hükümet Sistemlerinde Başkan Yardımcılı̆̆ Kurumu ve 2017 Anayasa Değişikliği İle Getirilen Sistemde Cumhurbaşkanı Yardımcılı̆̆ Kurumu Üzerine Karşılaştırmalı Bir Analiz, Zafer Gören Armağanı, 2017, pp. 440-500.

Ardıçoğlu, M. Artuk, Cumhurbaşkanlığı Kararnamesi. Ankara Barosu Dergisi, 2017, Vol. 75.3: pp. 19-51.

Ataay, Faruk; Adalet ve Kalkınma Partisi'nin 'Başkanlık Sistemi' Önerisi Üzerine Değerlendirme, Alternatif Politika, December 2013, pp. 266-294, p. 269.

Bakırcı, Fahri; Yasama Sürecinin Hılandırılması - Yasama Yetkisinin Devri vVe Nedenleri Üzerine, Kamu Hukukçuları Platformu Toplantısı Metni, İstanbul, 2930 Nisan 2017.

Batum, Süheyl; 1990'larda Dünyada ve Türkiye'de Siyasal Rejim Tartışmaları, Siyasal Rejim Tartışmaları içinde, Nihal İncioğlu (Ed.), TESEV Yayınları, Ankara, 2000, p.64.

Esen, Berk and Gumuscu, Sebnem; The Perils of "Turkish Presidentialism", Review of Middle East Studies, Middle East Studies Association of North America (MESA),Vol. 52, No. 1, April 2018, pp. 43-53, p. 44

Bulmer, Elliot; Presidential Legislative Power, International IDEA ConstitutionBuilding Primer 15, International Institute for Democracy and Electoral Assistance (International IDEA), 2017.

Carey, J. M., \& Shugart, M. P.; Calling out the Tanks or Filling out the Forms? In J. pp. 1-34.

Cheibub, J.A.; Presidentialism, Parliamentarism, and Democracy, Cambridge University Press, USA, 2007, p. 10. 
Council of Europe Convention on preventing and combating violence against women and domestic violence, (Avrupa Konseyi Sözleşmeler Dizisi - No. 210 Kadına Yönelik Şiddet ve Aile İçi Şiddetin Önlenmesi ve Bunlarla Mücadeleye Dair Avrupa Konseyi Sözleşmesi) İstanbul, 11.V.2011, https://rm.coe.int/1680462545, https://rm.coe.int/168046031c.

Council of State Decision (Danıştay); 8. Daire, 26.11.2013, E. 2013/5211, K. 2013/8692. Council of State Decision 5. Daire, 15.04.2003, E. 2000/1711, K. 2003/1421.

Dinler, Veysel; Cumhurbaşkan(lı̆̆) I Işlemlerinin Uygulamada Denetimi ve Kanunsuz Emir, Kamu Hukukçuları Platformu, İstanbul, Retrieved 5 10, 2019, from http://www.kamuhukukculari.org/upload/dosyalar/Veysel_Dinler.pdf.

Doğan, Bayram; Cumhurbaşkanlı̆̆l Hükümet Sisteminde Cumhurbaşkanliğı Kararnamelerinin Yasama Yetkisinin Devredilmezliği Bağlamında Değerlendirilmesi, SÜHFD, C. XXVIII, P. 3, 2020, pp. 965-1003.

Doyle, David, and Robert Elgie; Maximizing the reliability of cross-national measures of presidential power, British Journal of Political Science N. 46.4, 2016, pp. 731-741.International Political Science Association biennial conference, 20-24 Jul 2014, Canada.

Dursun, Hasan, Süper Başkanlık ya da Başkancı Parlamenter Sistem: Weimar Almanya'sı ile Rusya Federasyonu Örnekleri ve Çıkartılacak Dersler, TBB Dergisi, N. 67, 2006, p. 281.

Erdoğan, Mustafa; Başkanlık Sistemi, Latin Amerika Tecrübesi ve Türkiye, Liberal Perspektif Analiz, N. 3, Aralık 2016, p. 9. Voters dissatisfied with Democrats tends to vote Republican in the next election in cases where the leader of the Democratic Party wins the presidency. Thus it allows Republicans to be a majority in the House of Representatives.

Eren, Abdurrahman; Anayasa Mahkemesinin Kanun Hükmünde Kararnamelere Illişkin İçtihadı Doğrultusunda Cumhurbaşkanlı̆̆l Kararnamelerinin Değerlendirilmesi, Anayasa Yargıs1, Vol. 36, No. 1, 2019, pp. 1-72.

Esen, Selin; Anayasa Değişiklik Teklifinin Değerlendirilmesi, Ankara Barosu Dergisi, 2016/4, pp.45-71.

European Commission for Democracy through Law (Venice Commission); Turkey Opinion on the Amendments to the Constitution Adopted By The Grand National Assembly on 21 January 2017 and to be Submitted to a National Referendum on 16 April 2017, Strasbourg, 13 March 2017, Opinion No. 875/2017, CDL$\mathrm{AD}(2017) 005$, p. 25. See also Venice Commission, Report on Judicial Appointments, CDL-AD (2007)028, § 29; See also the Report on the independence of the judicial system, Part I: the independence of judges, CDL$\mathrm{AD}(2010) 004, \S 32$. 
Fish, S. Democracy Derailed in Russia the Failure of Open Politics, Cambridge University Press, Cambridge, 2005.

Fish, M. P., \& Kroenig, M.; The Handbook of National Legislature, (1 Ed.), Cambridge: Cambridge University Press, 2009, pp. 685-691.

Fish, M. Stephen, The Impact of the 1999-2000 Parliamentary and Presidential Elections On Political Party Development, Hesli, V. L., Hesli, V. L., Reisinger, W. M., \& Kennedy, S. J. (Eds.), The 1999-2000 Elections In Russia: Their Impact And Legacy, New York, Cambridge University Press, 2003, pp. 186212.

Fortin, J; Measuring presidential powers: Some pitfalls of aggregate measurement, International Political Science Review, V.34 (1), 2012, pp. 91-112.

Frye, T. A Politics of Institutional Choice Post-Communist Presidencies, Comparative Political Studies, Vol. 30(5), pp. 523-552.

Gönenç, Levent \& Kontac1, Ali, Ersoy; 2017 Tarihli Anayasa Değiş̧ikliği Sonrasinda Yasama - Yürütme Ilişskileri, TBB Dergisi, N. 145, 2019, pp. 54-79.

Gönenç, Levent; Hükümet Sistemi Tartışmalarında Başkanlı Parlamenter Sistem Seçeneğ $i$, Güncel Hukuk, S.44, 2007, pp.39-43.

Gönenç, Levent; Uygulamada Cumhurbaşkanlığl Hükümet Sistemi, TEPAV, Türkiye Ekonomi Politikaları Araştırma Vakfı, Hukuk Çalışmaları Merkezi, Mayıs 2018, N. 2018-20.

Gönenç, Levent; Türkiye'de Başkanlık Sistemi Tartışmaları, Güncel Hukuk, Haziran, 2011, pp. 14-16, p.11-12.

Goplerud, M., \& Schleiter, P.; An Index of Assembly Dissolution Powers, Comparative Political Studies, Vol. 49(4), 2016, pp. 427-456, p.403-432.

Gözler, Kemal; 1982 Anayasası Hâlâ Yürürlükte mi? Anayasasızlaştırma Üzerine Bir Deneme (Versiyon 4), 30 Mayıs 2016, Retrieved Ocak 2017, 01, from http://www.anayasa.gen.tr/anayasasizlastirma-v4.pdf.

Gözler, Kemal; Türk Anayasa Hukuku Dersleri, (22 $2^{\text {nd }}$ Ed.), Bursa, Ekin Yayınevi, 2018.

Gözler, Kemal; Türk Anayasa Hukuku, $3^{\text {rd }}$ Ed. Ekin Yayınevi, Bursa, Ocak 2019.

Gözler, Kemal; Elveda Kuvvetler Ayrllı̆̆, Elveda Anayasa, 2016, $\mathrm{http}: / / \mathrm{www}$.anayasa.gen.tr/elveda-anayasa-v2.htm.

Gülener, Serdar; Başkanlık Sistemlerinde Denge ve Denetleme, Siyaset, Ekonomi ve Toplum Araştırmaları Vakfı, SETA Yayınları 66, I. Baskı, 2016,

Günday, Metin; İdare Hukuku, 8. Baskı, Ankara, 2003. 
İba, Şeref; Söyler, Yasin; Yeni Hükümet Sisteminde Cumhurbaşkanlığı Kararnamesi Ile Cumhurbaşkanı Kararının Nitelik Farkı ve Hukuki Sonuçları, Anayasa Yargis1, Vol.: 36, No. : 1, 2019, pp. 195-223. p. 216.

Ishiyama, John T.; Kennedy, Ryan; Superpresidentialism and Political Party Development in Russia, Ukraine, Armenia and Kyrgyzstan, Europe-Asia Studies, Vol. 53, No. 8, 2001, 1177-1191.

Javier Hurtado; Gobiernos y Democracia, Instituto Federal Electoral, Mexico, 2012, p. 36.

Kılınç, Doğan; Türkiye'de Bitmeyen Tartışma: Hükümet Sistemi Üzerine Değerlendirmeler, Ankara Hacı Bayram Veli Üniversitesi Hukuk Fakültesi Dergisi, N.20.1, 2016, pp.447-510.

Kontac1, Ali Ersoy; Kırılgan Demokrasilerde Siyasal Örgütlenme Özgürlüğü, Savaş Kitapevi, Ankara, 2016.

Larkins, Christopher Michael. The Legacies of Hyper-Presidentialism: ExecutiveJudicial Relations, Constitutional Cultures, and the Future of Democratic Governance in Argentina and Peru, University of Southern California, 1998.

Law No. 2575, Art. 24 of Council of State Law, https://www.mevzuat.gov.tr/MevzuatMetin/1.5.2575.pdf.

Lijphart, Arend, Patterns of Democracy: Government Forms and Performance in Thirty-Six Countries, 2nd edition, Yale University Press, 2012.

Linz, Juan J. ; The Perils of Presidentialism, Journal of Democracy, Volume 1, Number 1, winter 1990, pp. 51-69.

M. Carey, \& M. P. Shugart (Edp.); Executive Decree Powers, New York: Cambridge University Press, 1998.

Mainwaring, P. \& Shugart, M. P; Juan Linz, Presidentialism, and Democracy: A Critical Appraisal, Comparative Politics, Vol. 29(4), pp. 449-471, p.464.

Manning, John F.; Separation of Powers as Ordinary Interpretation, Harvard Law Review, 1939, 2011, pp. 1944-45.

Martínez-Gallardo, C. ; Designing Cabinets: Presidential Politics and Ministerial Instability, Journal of Politics in Latin America, Vol. 6(2), pp. 3-38, p.17.

Metcalf, Lee Kendall; Measuring Presidential Power, Comparative Political Studies, V.33 (5), 2000, pp. 660-685, p.127.

Metcalf, Lee Kendall, The evolution of presidential power in Estonia 1920-1992, Journal of Baltic Studies, Vol. 29(4), 1998, pp. 333-352.

O'Donnell, Guillermo; Delegative Democracy, Journal of Democracy, N.1, 5, 1994, pp. 55-69. 
Onar, Erdal; Türkiye'nin Başkanlık veya Yart-Başkanlı Sistemine Geçmesi Düşünülmeli midir? Başkanlık Sistemi içinde, Teoman Ergül (Ed.), Türkiye Barolar Birliği Yay. Ankara, 2005, pp. 71-103.

Ozan Ergül; Yeni Rejimin Kodlarl: Cumhurbaşkanllğg Kararnameleri, Güncel Hukuk, 2018, N..173, pp..30-34.

Özbudun, Ergun; Presidentialism vs. Parliamentarism in Turkey, Policy Brief, July 2012, 01, 1-4, p.2.

Özbudun, Ergun, AKP at the Crossroads: Erdoğan's Majoritarian Drift, South European Society and Politics, 19:2, pp. 155-167, 2014, p. 163.

Özbudun, Ergun; Turkey's Judiciary and the Drift Toward Competitive Authoritarianism, The International Spectator, 50:2, 42-55, 2015, DOI: 10.1080/03932729.2015.1020651.

Özbudun, Ergun; Başkanlık Sistemi ve Türkiye, Analiz, Liberal Perspektif, Özgürlük Araştırmaları Derneği, No.1, Mayıs 2015.

Özbudun, Ergun; Türk Usulüne Göre Başkanlık Rejimi, http://www.milliyet.com.tr/turk-usulune-gorebaskanliksistemi/gundem/gundemyazardetay/15.12.2012/1641997/default.htm (04.07.2015).

Özsoy Boyunsuz, Şule and Esen, Berk, Türkiye İ̧̧ın Yeni Bir Hükümet Sistemi Hükümet Sistemi Kaynakl Sorunlar Ve Çözüm Önerileri, Politika Notu, İstanbul Politik Araştırmalar Enstitüsü, Aralık 2020, 018, retrieved from https://d4b693e1-c592-4336-bc6a-

36c134d6fb5e.filesusr.com/ugd/c80586_6a562ba050bb4af7b0acf37226c53109 .pdf.

Özsoy Boyunsuz, Şule; Siyasi Parti Sistemlerine Göre Başkanlık Rejiminin Türleri, Amme İdaresi Dergisi, Volume 49, Number 3, Eylül 2016, pp.1-40.

Özsoy Boyunsuz, Şule; The AKP'S proposal for a "Turkish type of presidentialism" in comparative context, Turkish Studies, 17(1), 2016, pp. 68-90. Retrieved 3 12, 2019, from https://tandfonline.com/doi/full/10.1080/14683849.2015.1135064.

Özsoy Boyunsuz, Şule; Başkanlı Parlamenter Sistem, Gözden Geçirilmiş 2. Baskı, 2014, Onikilevha Yayıncılık, İstanbul.

Presidential Decree No. 9; Presidential Decree on the Procedures and Principles for the Ratification of International Treaties (Milletlerarası Andlaşmaların Onaylanmasına İlişkin Usul Ve Esaslar Hakkında Cumhurbaşkanlığı Kararnamesi), Date: 15/7/2018, 30479. https://www.mevzuat.gov.tr/MevzuatMetin/19.5.9.pdf

Renewal of Election of the Grand National Assembly of Turkey and the Presidential Election 15 Article 116- (As amended on April 16, 2017; Act No. 6771). 
Rose-Ackerman, Susan, and Diane A. Desierto; Hyper-presidentialism: Separation of powers without checks and balances in Argentina and Philippines, Berkeley Journal of International Law, V.29, 2011.

Sar, Enes, Cakiroglu, Berivan, Ozdogan, Emre; The Principle of Formal Parallelism Or the Principle of Congruent Form in Turkish Administrative Law, 20 GSI Articletter 115 (2019), pp. 115 to 128.

Schmidt, Gregory D.; Delegative Democracy in Peru? Fujimori's 1995 Landslide and the Prospects for 2000, Journal of Interamerican Studies and World Affairs, Spring, 2000, Vol. 42, No. 1 (Spring, 2000), pp. 99-132.

Scotti, Valentina Rita; Constitutional dismemberment via referenda: A Comparative Overview, Revista de Investigações Constitucionais, 7(3), 2020, pp. 795-811. Epub January 06, 2021.https://doi.org/10.5380/rinc.v7i3.74334.

Serap, Yazıcı; Başkanlık Sistemleri: Türkiye Iç̧in Bir Değerlendirme, Başkanlık Sistemi içinde, Teoman Ergül (Ed.), Türkiye Barolar Birliği Yayınları, Ankara, 2005, pp. 125-145.

Sevgili Gençay, Fatma Didem; Cumhurbaşkanlığ Kararnamelerinin Yargısal Denetimi: İlk Kararlar - İlk İzlenimler, TBB Dergisi, 2020, N. 151, pp.1-27.

Shugart, Matthew Soberg, and John M. Carey; Presidents and assemblies: Constitutional design and electoral dynamics, Cambridge University Press, 1992.

Siaroff, A.; Comparative Presidencies: The Inadequacy of the Presidential, SemiPresidential and Parliamentary Distinction, European Journal of Political Research, V. 42(287), 2003, pp. 287-312, p. 294-295.

Şirin, Tolga; Işslemeyen Sistemlerin Fonksiyonel Olmayan Yanıtı: Cumhurbaşkanliğ Kararnamesi, Anayasa Hukuku Dergisi, Vol. 7, N. 14, 2018, pp. 289-356.

Strategic Comments, Turkey's new presidential system, Vol. 24 (6), 2018.

Tahmazoğlu Üzeltürk, Sultan; Anayasa Değişikliğinde Cumhurbaşkanı, Güncel Hukuk, Şubat 2017, pp. 12-14.

Taş, Hakkı; Turkey - From Tutelary to Delegative Democracy, Third World Quarterly, 36:4, 776-791, 2015, DOI: 10.1080/01436597.2015.1024450.

Teziç, Erdoğan; Anayasa Hukuku, Beta, 19. Bask1, İstanbul, 2015, p.37-38.

The Decision Regarding Termination of the Istanbul Convention Number 3718. "Ístanbul Sözleşmesinin feshi hakkında karar", Date: 20/03/2021, Number 31429, Official Gazette

Turan, Menaf; Türkiye’nin Yeni Yönetim Düzeni: Cumhurbaşkanlı̆̆ Hükümet Sistemi, Social Sciences Research Journal, Volume 7, Issue 3, September 2018, pp. 42-91. 
Strategic Comments, Turkey's new presidential system. (2018, Ağustos 7), 24:6, v$\begin{array}{llll}\text { vi, Retrieved January } & 5, & 2019, & \text { from }\end{array}$ https://doi.org/10.1080/13567888.2018.1508950

Uluşahin, Nur; Anayasal Bir Tercih Olarak Başkanlık Sistemi, Yetkin Yayınları, Ankara, 1999.

Ulusoy, Ali; Aralık 2016 Anayasa Teklifi Neler Getiriyor, Neler Götürüyor? 2017, Anayasa. gen. $\operatorname{tr}$ (online), pp. 1-9.

Ulusoy, Ali; Cumhurbaşkanlığı Kararnameleri: Varoluşsal, Yapısal ve Hukuksal Bir Değerlendirme,Anayasa Yargısı, Vol: 37, N. 2, Aralık 2020, pp.31-66, p. 62.

Uzun, Cem Duran; 6771 No. ll Kanunla Anayasada Yarglyla Ilgili Yapılan Düzenlemeler, Uyuşmazlık Mahkemesi Dergisi, V. 0, Issue 11, 2018, pp. 409443.

Venice Commission; Joint Opinion on the draft Law of the Judicial System and the Status of Judge in Ukraine, 2010, p. 8. https://www.venice.coe.int/webforms/documents/default.aspx?pdffile=CDL$\mathrm{AD}(2010) 004-\mathrm{e}, 16.02 .2021$.

Venice Commission; Opinion No. 875/2017, CDL-AD(2017)005, § 108, 17.

Waldron, J; Separation of Powers in Thought and Practice, Boston College Law Review, 54(2), pp.433-468, p.459.

Yavuz, Atar; Cumhurbaşkanlığı Kararnamelerinin Hukuki Rejimi ve Anayasallı Denetimi, 2019, https://www.anayasa.gov.tr/media/6184/yavuz-atar.pdf, p. 259.

Yeniay, Lokman\& Yeniay, Gülden; Türk Hukukunda Yürütme Organinin Düzenleme Yetkisi Ve Cumhurbaşkanliği Kararnamesi, Anayasa Yargısı, Vol.: 36, No. : 1, (2019), pp. 105-138.

Yıldırım, Turan; Cumhurbaşkanlığı Kararnameleri, Marmara Üniversitesi Hukuk Fakültesi Hukuk Araştırmaları Dergisi, Vol. 23., No. 2. 2017, pp.13-28.

Yılmaz, Harun; Türk Hukukunda Düzenleme Yetkisinin Tarihsel Gelişimi ve Niteliği, Türkiye Barolar Birliği Dergisi, 2014, (110), pp. 219-240.p. 230. 


\section{Turkish Constitutional Court Decisions}

1. AYM 22.01.2020, E.2018/125, K.2020/4.

2. AYM 23.01.2020, E.2019/31, K.2020/5.

3. AYM 23.01.2020, E.2019/78, K. 2020/6.

4. AYM, 01.06.2005, E.2004/60, K.2005/33.

5. AYM, 11.06.2003, E.2001/346, K.2003/63.

6. AYM, 11/06/2020,E.2018/155, K.2020/27.

7. AYM, 12.06.2020, E.2019/105, K.2020/30.

8. AYM, 12/6/2020, E.2019/105, K. 2020/30.

9. AYM, 14/12/2016, E.2016/139, K.2016/188.

10. AYM, 16.9.1993, E.1992/26, K. 1993/28.

11. AYM, 18/1/2018, E.2016/180, K.2018/4.

12. AYM, 22.01.2020, E.2018/125, K.2020/4.

13. AYM, 23.01.2020, E.2019/31, K.2020/5.

14. AYM, 23.02.2006, E.2005/42, K.2006/27.

15. AYM, 23.10.1969, E.1967/41, K.1969/57.

16. AYM, 24/7/2019, E.2016/205, K.2019/63.

17. AYM, 25/06/2020 E.2018/128, K.2020/32.

18. AYM, 27.10.2011, E.2011/60, K. 2011/147.

19. AYM, 28/12/2017, E.2016/150, K.2017/179.

20. AYM, 29.11.2006, E.2004/102, K.2005/96.

21. AYM, 29/11/2017 E.2017/51, K.2017/163.

22. AYM, 30.12.2020, E.2019/71, K.2020/82.

23. AYM, 4.5.2017,E.2015/41, K. 2017/98.

24. AYM, 5.2.1992, E.1990/22, K.1992/6.

25. AYM, 6/6/2013, E.2013/47, K.2013/72. 
